Prepared in cooperation with the City of Houston

\title{
Simulation of the Effects of Different Inflows on Hydrologic Conditions in Lake Houston With a Three-Dimensional Hydrodynamic Model, Houston, Texas, 2009-10
}
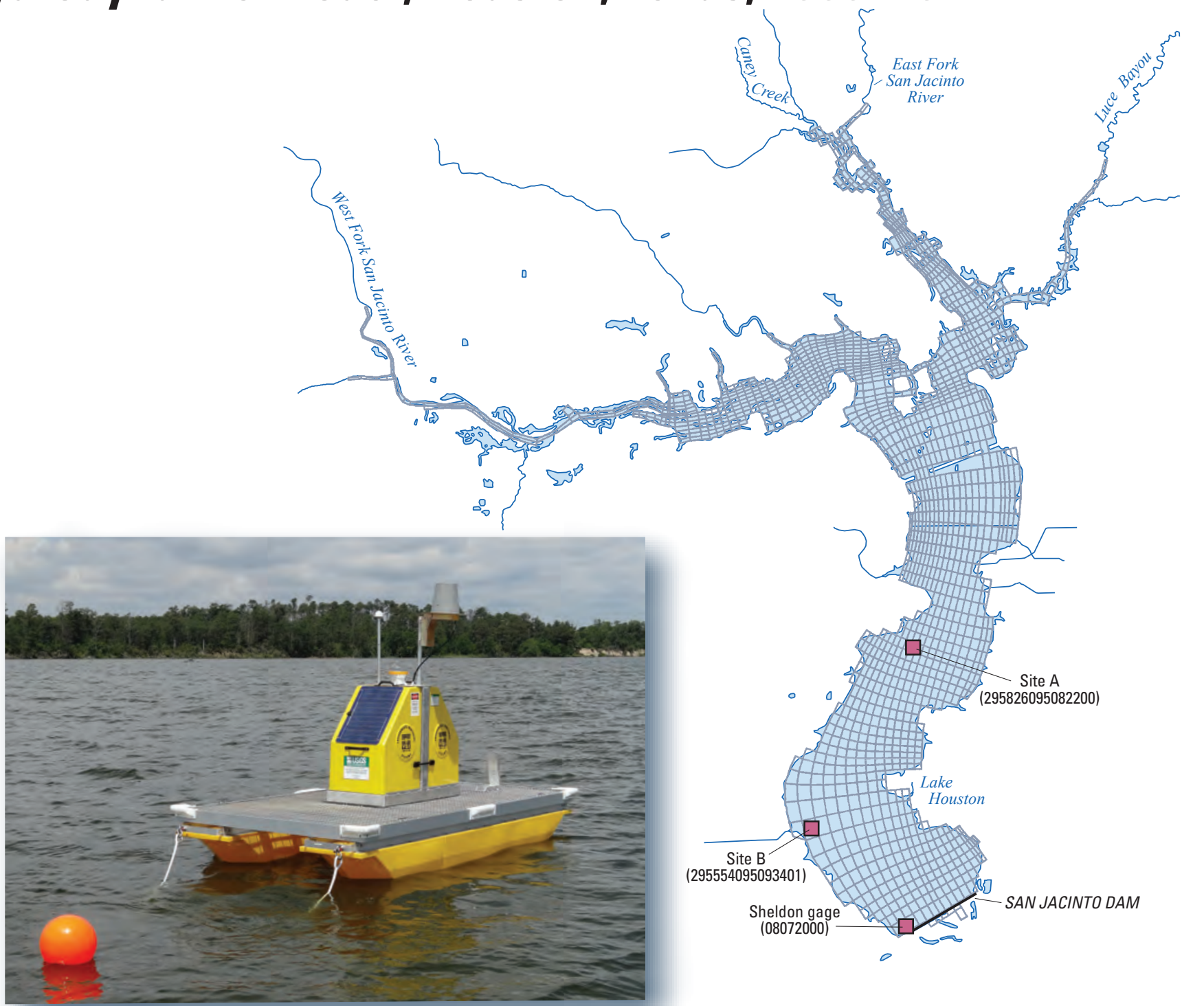

Scientific Investigations Report 2015-5153 
Covers, Floating platform auto-reel system for vertical profiling of real-time water-quality data at U.S. Geological Survey reservoir station 295554095093401 Lake Houston at mouth of Jack's Ditch near Houston, Texas (site B). 


\section{Simulation of the Effects of Different Inflows on Hydrologic Conditions in Lake Houston With a Three-Dimensional Hydrodynamic Model, Houston, Texas, 2009-10}

By Samuel H. Rendon and Michael T. Lee

Prepared in cooperation with the City of Houston

Scientific Investigations Report 2015-5153 


\title{
U.S. Department of the Interior SALLY JEWELL, Secretary
}

\section{U.S. Geological Survey \\ Suzette M. Kimball, Acting Director}

\author{
U.S. Geological Survey, Reston, Virginia: 2015
}

For more information on the USGS - the Federal source for science about the Earth, its natural and living resources, natural hazards, and the environment—visit http://www.usgs.gov or call 1-888-ASK-USGS.

For an overview of USGS information products, including maps, imagery, and publications, visit http://www.usgs.gov/pubprod/.

Any use of trade, firm, or product names is for descriptive purposes only and does not imply endorsement by the U.S. Government.

Although this information product, for the most part, is in the public domain, it also may contain copyrighted materials as noted in the text. Permission to reproduce copyrighted items must be secured from the copyright owner.

Suggested citation:

Rendon, S.H., and Lee, M.T., 2015, Simulation of the effects of different inflows on hydrologic conditions in Lake Houston with a three-dimensional hydrodynamic model, Houston, Texas, 2009-10: U.S. Geological Survey Scientific Investigations Report 2015-5153, 42 p., http://dx.doi.org/10.3133/sir20155153.

ISSN 2328-0328 (online) 


\section{Contents}

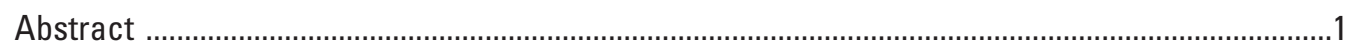

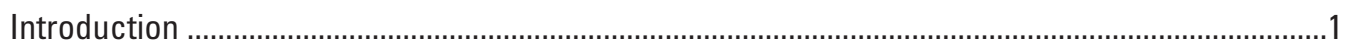

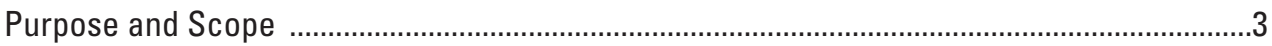

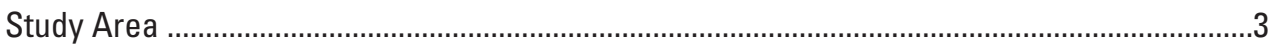

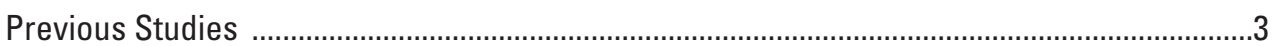

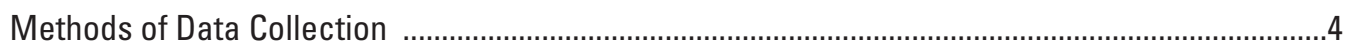

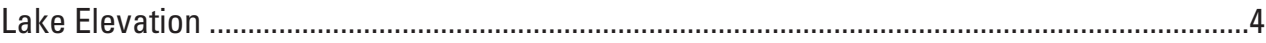

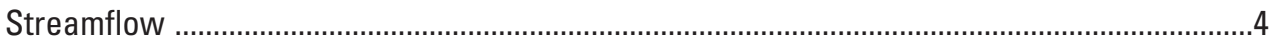

Specific Conductance and Water Temperature ………......................................................

Meteorological Data ....................................................................................................

Development of a Three-Dimensional Hydrodynamic Model .......................................................

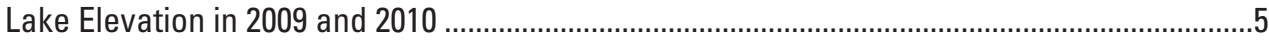

Inflows to Lake Houston From the Western and Eastern Watersheds in 2009 and 2010 .........7

Specific Conductance and Water Temperature in 2009 and 2010 .........................................7

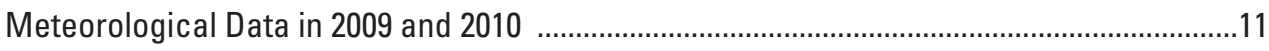

Model Description and Inputs ...........................................................................................11

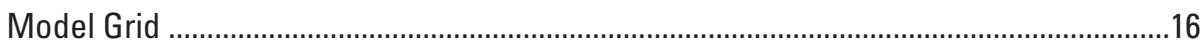

Modeled Streamflow ......................................................................................................18

Specific Conductance and Water Temperature ………................................................18

Meteorological Data .............................................................................................22

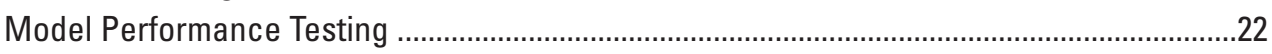

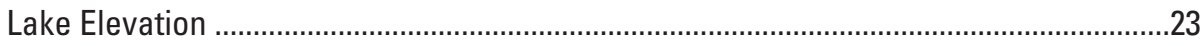

Salinity Computed From Specific Conductance and Water Temperature ......................25

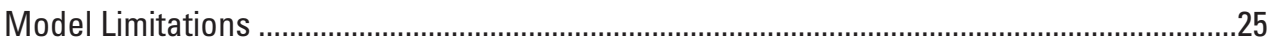

Simulation of the Effects of Different Inflows on Hydrologic Conditions in Lake Houston ............32

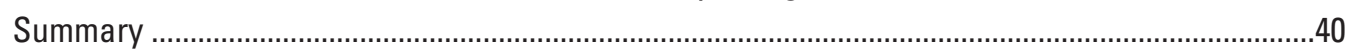

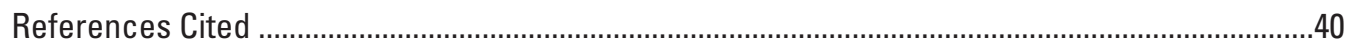

\section{Figures}

1. Map showing Lake Houston drainage area and locations of U.S. Geological Survey streamflow-gaging stations and reservoir stations ...........................................

2. Graphs showing lake elevations measured at U.S. Geological Survey reservoir station 08072000 Lake Houston near Sheldon, Texas, in 2009 and 2010 ..........................6

3. Graphs showing combined inflow from the western and eastern watersheds to Lake Houston, near Houston, Texas, in 2009 and 2010 ..................................................

4. Graphs showing specific conductance measured at U.S. Geological Survey streamflow-gaging stations 08068500 Spring Creek near Spring, Texas, and 08070200 East Fork San Jacinto River near New Caney, Tex., in 2009 and 2010

5. Graphs showing water temperature measured at U.S. Geological Survey streamflow-gaging stations 08068500 Spring Creek near Spring, Texas, and 08070200 East Fork San Jacinto River near New Caney, Tex., in 2009 and 2010

6. Graphs showing specific conductance measured at a depth of 12 feet at U.S. Geological Survey reservoir stations 295826095082200 Lake Houston south Union Pacific Railroad Bridge near Houston, Texas (site A), and 295554095093401 Lake Houston at mouth of Jack's Ditch near Houston, Tex. (site B), in 2009 and 2010 
7. Graph showing water temperature measured at 1-, 6-, 12-, and 16-foot depths at U.S. Geological Survey reservoir station 295554095093401 Lake Houston at mouth of Jack's Ditch near Houston, Texas (site B), 2009

8. Wind-rose graphs depicting hourly wind speed and direction values measured at the National Weather Service meteorological station at George Bush Intercontinental Airport near Houston, Texas, in 2009 and 2010

9. Graphs showing hourly precipitation measured at the National Weather Service meteorological station at George Bush Intercontinental Airport near Houston, Texas, in 2009 and 2010

10. Map showing conceptual layout of Lake Houston Environmental Fluid Dynamics Code model with grid and boundary condition cells for Lake Houston, near Houston, Texas

11. Map showing gaged and ungaged areas of tributary watersheds providing inflows to Lake Houston, near Houston, Texas

12. Graphs showing the relation between salinity, in parts per thousand, and streamflow, in cubic feet per second, during 2009-10 for U.S. Geological Survey (USGS) streamflow-gaging station 08068500 Spring Creek near Spring, Texas, and USGS streamflow-gaging station 08070200 East Fork San Jacinto River near New Caney, Tex.

13. Graph showing simulated and measured lake elevations at U.S. Geological Survey reservoir station 08072000 Lake Houston near Sheldon, Texas, 2009 .23

14. Graph showing simulated and measured lake elevations at U.S. Geological Survey reservoir station 08072000 Lake Houston near Sheldon, Texas, 2010

15. Graphs showing simulated salinity and salinity computed from measured specific conductance measured in 2009 at U.S. Geological Survey reservoir stations on Lake Houston, near Houston, Texas

16. Graphs showing simulated salinity and salinity computed from measured specific conductance measured in 2010 at U.S. Geological Survey reservoir stations on Lake Houston, near Houston, Texas

17. Graphs showing simulated and measured water temperature at U.S. Geological Survey reservoir stations on Lake Houston, near Houston, Texas, in 2009

18. Graphs showing simulated and measured water temperature at U.S. Geological Survey reservoir stations on Lake Houston, near Houston, Texas, in 2010

19. Map showing locations of representative cross sections used to illustrate simulations from the three-dimensional hydrodynamic model of Lake Houston, near Houston, Texas

20. Maps and graphs showing examples of modeled changes in water residence time in Lake Houston, near Houston, Texas, from April 19, 2009, to April 22, 2009, in response to an inflow event

21. Maps and graphs showing examples of modeled changes in salinity in Lake Houston, near Houston, Texas, from April 19, 2009, to April 22, 2009, in response to an inflow event

22. Graph showing simulated depth-averaged residence time at each of the five representative cross sections and inflows from the western and eastern watersheds for 2009 from the Environmental Fluid Dynamics Code model of Lake Houston, near Houston, Texas

23. Graph showing model results for residence time over time at cross section $D-D^{\prime}$ for 2010 for increased flow from West Fork San Jacinto River and increased flow from Luce Bayou to Lake Houston, near Houston, Texas 


\section{Tables}

1. Data collected at U.S. Geological Survey (USGS) streamflow-gaging stations in the San Jacinto River Basin upstream from Lake Houston and at USGS reservoir stations in Lake Houston, near Houston, Texas, 2009 and 2010

2. Average annual inflow for each of the tributaries to Lake Houston, near Houston, Texas, in 2009 and 2010

3. Model input files for the Environmental Fluid Dynamics Code hydrodynamic model of Lake Houston, near Houston, Texas

4. Gaged watershed area, ungaged watershed area, ratio of ungaged to gaged watershed area, and applied scalar factor for estimating the inflows from all tributaries to Lake Houston, near Houston, Texas, during 2009

5. Performance evaluation statistics for simulated lake elevation relative to measured lake elevation in Lake Houston, near Houston, Texas, 2009 and 2010

6. Performance evaluation statistics for simulated salinity and salinity computed from measured specific conductance at U.S. Geological Survey reservoir stations 295826095082200 Lake Houston south Union Pacific Railroad Bridge near Houston, Texas, and 295554095093401 Lake Houston at mouth of Jack's Ditch near Houston, Tex., 2009 and 2010

7. Performance evaluation statistics for simulated and measured water temperature at U.S. Geological Survey reservoir stations 295826095082200 Lake Houston south Union Pacific Railroad Bridge near Houston, Texas, and 295554095093401 Lake Houston at mouth of Jack's Ditch near Houston, Tex., 2009 and 2010 


\section{Conversion Factors}

Inch/Pound to SI

\begin{tabular}{|c|c|c|}
\hline Multiply & By & To obtain \\
\hline \multicolumn{3}{|c|}{ Length } \\
\hline inch (in.) & 2.54 & centimeter $(\mathrm{cm})$ \\
\hline inch (in.) & 25.4 & millimeter (mm) \\
\hline foot $(\mathrm{ft})$ & 0.3048 & meter $(\mathrm{m})$ \\
\hline mile (mi) & 1.609 & kilometer $(\mathrm{km})$ \\
\hline \multicolumn{3}{|c|}{ Area } \\
\hline acre & 4,047 & square meter $\left(\mathrm{m}^{2}\right)$ \\
\hline acre & 0.004047 & square kilometer $\left(\mathrm{km}^{2}\right)$ \\
\hline square foot $\left(\mathrm{ft}^{2}\right)$ & 0.09290 & square meter $\left(\mathrm{m}^{2}\right)$ \\
\hline square mile $\left(\mathrm{mi}^{2}\right)$ & 2.590 & square kilometer $\left(\mathrm{km}^{2}\right)$ \\
\hline \multicolumn{3}{|c|}{ Volume } \\
\hline cubic foot $\left(\mathrm{ft}^{3}\right)$ & 28.32 & cubic decimeter $\left(\mathrm{dm}^{3}\right)$ \\
\hline cubic foot $\left(\mathrm{ft}^{3}\right)$ & 0.02832 & cubic meter $\left(\mathrm{m}^{3}\right)$ \\
\hline acre-foot (acre-ft) & 1,233 & cubic meter $\left(\mathrm{m}^{3}\right)$ \\
\hline acre-foot (acre-ft) & 0.001233 & cubic hectometer $\left(\mathrm{hm}^{3}\right)$ \\
\hline \multicolumn{3}{|c|}{ Flow rate } \\
\hline foot per second $(\mathrm{ft} / \mathrm{s})$ & 0.3048 & meter per second $(\mathrm{m} / \mathrm{s})$ \\
\hline cubic foot per second $\left(\mathrm{ft}^{3} / \mathrm{s}\right)$ & 0.02832 & cubic meter per second $\left(\mathrm{m}^{3} / \mathrm{s}\right)$ \\
\hline \multicolumn{3}{|c|}{ Mass diffusivity and kinematic viscosity } \\
\hline square foot per second $\left(\mathrm{ft}^{2} / \mathrm{s}\right)$ & 0.09290 & square meter per second $\left(\mathrm{m}^{2} / \mathrm{s}\right)$ \\
\hline
\end{tabular}

Temperature in degrees Celsius $\left({ }^{\circ} \mathrm{C}\right)$ may be converted to degrees Fahrenheit $\left({ }^{\circ} \mathrm{F}\right)$ as follows:

${ }^{\circ} \mathrm{F}=\left(1.8 \times{ }^{\circ} \mathrm{C}\right)+32$.

Temperature in degrees Fahrenheit $\left({ }^{\circ} \mathrm{F}\right)$ may be converted to degrees Celsius $\left({ }^{\circ} \mathrm{C}\right)$ as follows:

${ }^{\circ} \mathrm{C}=\left({ }^{\circ} \mathrm{F}-32\right) / 1.8$.

Vertical coordinate information is referenced to the North American Vertical Datum of 1988 (NAVD 88).

Horizontal coordinate information is referenced to the North American Datum of 1983 (NAD 83). 


\title{
Simulation of the Effects of Different Inflows on Hydrologic Conditions in Lake Houston With a Three-Dimensional Hydrodynamic Model, Houston, Texas, 2009-10
}

\author{
By Samuel H. Rendon and Michael T. Lee
}

\section{Abstract}

Lake Houston, an important water resource for the Houston, Texas, area, receives inflows from seven major tributaries that compose the San Jacinto River Basin upstream from the reservoir. The effects of different inflows from the watersheds drained by these tributaries on the residence time of water in Lake Houston and closely associated physical and chemical properties including lake elevation, salinity, and water temperature are not well known. Accordingly, the U.S. Geological Survey (USGS), in cooperation with the City of Houston, developed a three-dimensional hydrodynamic model of Lake Houston as a tool for evaluating the effects of different inflows on residence time of water in the lake and associated physical and chemical properties. The Environmental Fluid Dynamics Code (EFDC), a gridbased, surface-water modeling package for simulating three-dimensional circulation, mass transport, sediments, and biogeochemical processes, was used to develop the model of Lake Houston. The Lake Houston EFDC model was developed and calibrated by using 2009 data and verified by using 2010 data. Three statistics (mean error, root mean square error, and the Nash-Sutcliffe model efficiency coefficient) were used to evaluate how well the Lake Houston EFDC model simulated lake elevation, salinity, and water temperature. The residence time of water in reservoirs is associated with various physical and chemical properties (including lake elevation, salinity, and water temperature). Simulated and measured lake-elevation values were compared at USGS reservoir station 08072000 Lake Houston near Sheldon, Tex. The accuracy of simulated salinity and water temperature values was assessed by using the salinity (computed from measured specific conductance) and water temperature at two USGS monitoring stations: 295826095082200 Lake Houston south Union Pacific Railroad Bridge near Houston, Tex., and 295554095093401 Lake Houston at mouth of Jack's Ditch near Houston, Tex. Specific conductance and water temperature were measured at as many as four different depths at each of the two monitoring stations during 2009 and then used for assessing the accuracy of simulated values of salinity and water temperature during 2010. The performance evaluation statistics indicate that the model performed satisfactorily. The calibrated model was used to simulate two possible inflow scenarios to evaluate the changes in the residence time of water in Lake Houston. The two scenarios tested were an increased inflow of approximately 300 cubic feet per second for 1 month (May 2010) from two watersheds: the West Fork San Jacinto River and Luce Bayou. These scenarios were chosen to mimic the effects of possible small releases or diversions of water from outside the San Jacinto River Basin into the basin (or directly into the lake) on the residence time of water in Lake Houston. During the time of increased inflow for the two scenarios tested, maximum residence time decreased slightly from approximately 106 to 97 days.

\section{Introduction}

Lake Houston is an important water resource for the rapidly growing Houston, Texas, metropolitan area (Texas State Data Center, 2012a, 2012b). The City of Houston, the regional water provider for the Houston metropolitan area, relies primarily on surface water to meet the growing demands for municipal and industrial water supplies. According to the City of Houston Web site, in 2015, about 71 percent of the water supply came from surface-water sources, and about 29 percent came from groundwater sources (City of Houston, 2015). The city has the goal of reducing groundwater usage to less than 20 percent of the total supply, and surface-water usage will increase to meet future water demands (City of Houston, 2015). The percentage of water supply for the City of Houston provided by Lake Houston has been steadily increasing; Lake Houston supplied between 10 and 20 percent of the total source-water supply for the City of Houston as of 2015 (City of Houston, 2015). In addition to providing drinking water, Lake Houston is an important recreational resource for the Houston area.

Lake Houston receives inflows from seven major tributaries (fig. 1). The effects of different inflows from the watersheds drained by these tributaries on hydrologic conditions of the lake, including the residence time of water in Lake Houston and associated physical and chemical properties (including lake elevation, salinity, and water temperature), are not well known. Accordingly, the U.S. Geological Survey (USGS), in cooperation with the City of Houston, developed 


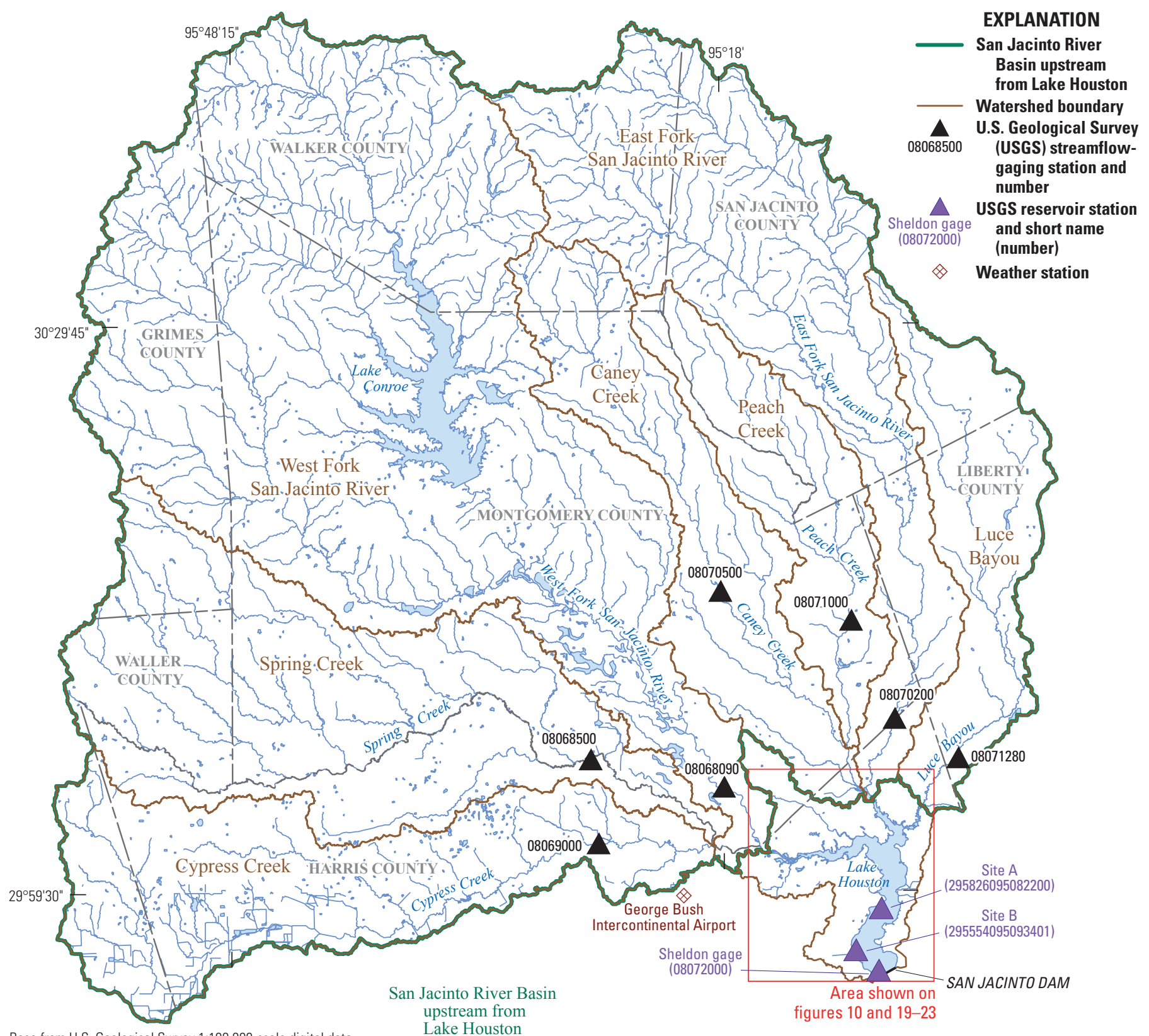

Base from U.S. Geological Survey 1:100,000-scale digital data Albers Equal Area projection North American Datum of 1983

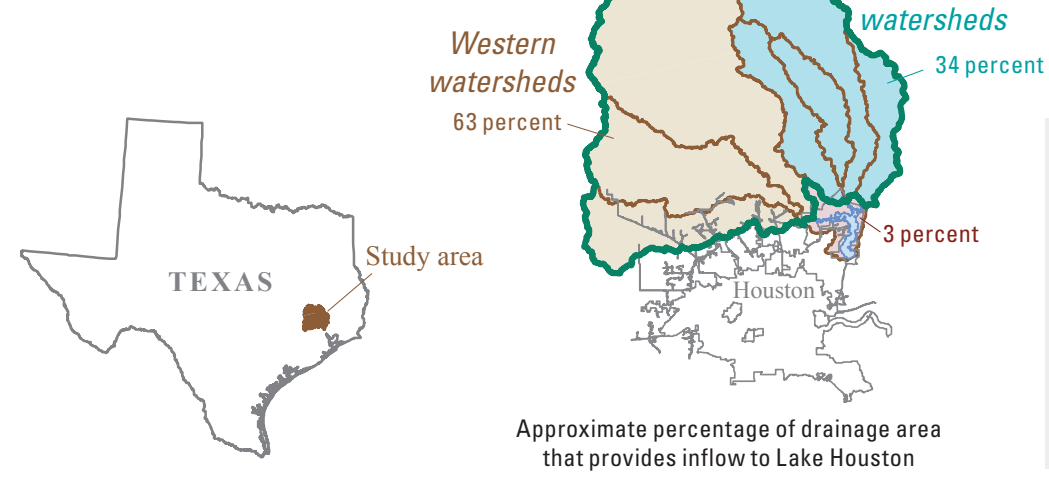

\begin{tabular}{cl}
$\begin{array}{c}\text { USGS } \\
\text { station number }\end{array}$ & \multicolumn{1}{c}{ USGS station name } \\
\hline 08068090 & West Fork San Jacinto River above Lake Houston near Porter, Tex. \\
08068500 & Spring Creek near Spring, Tex. \\
08069000 & Cypress Creek near Westfield, Tex. \\
08070200 & East Fork San Jacinto River near New Caney, Tex. \\
08070500 & Caney Creek near Splendora, Tex. \\
08071000 & Peach Creek at Splendora, Tex. \\
08071280 & Luce Bayou above Lake Houston near Huffman, Tex. \\
08072000 & Lake Houston near Sheldon, Tex. \\
295826095082200 & Lake Houston south Union Pacific Railroad Bridge near Houston, Tex. \\
295554095093401 & Lake Houston at mouth of Jack's Ditch near Houston, Tex.
\end{tabular}

Figure 1. Lake Houston drainage area and locations of U.S. Geological Survey streamflow-gaging stations and reservoir stations. 
a three-dimensional hydrodynamic model of Lake Houston as a tool for evaluating the effects of different inflows on the residence time of water in the lake and associated physical and chemical properties.

\section{Purpose and Scope}

The purpose of this report is to describe a threedimensional hydrodynamic model of Lake Houston, model performance testing, and simulation of the effects of different inflows on water residence time and other lake properties during a simulation period from 2009 through 2010. Hydrological and meteorological data collected during 2009 were used to develop and calibrate the model; data collected during 2010 were used to verify the model. An overview is provided of the limitations and potential applications of the model, including how physical and chemical properties associated with residence time can change in response to different inflows from storm events and how the model can be applied to evaluate the residence time of water in the lake in response to two different inflow scenarios.

\section{Study Area}

Lake Houston (fig. 1) is a eutrophic to hypertrophic reservoir about 25 miles (mi) northeast from the center of downtown Houston (Liscum and East, 2000). The San Jacinto Dam (referred to locally as the "Lake Houston Dam") was built during 1951-53 (Dowell, 1964) and impounds the seven major tributaries that drain the San Jacinto River Basin upstream from Lake Houston. The City of Houston built the reservoir to provide water for municipal, industrial, recreational, mining, and irrigation purposes (Dowell, 1964). The reservoir has a capacity of about 146,700 acre-feet and a surface area of 12,240 acres; mean depth is about 12 feet (ft), and maximum depth is about $50 \mathrm{ft}$ (Liscum and East, 2000; Texas Water Development Board, 2012).

Lake Houston is at the outlet of the 2,785-squaremile $\left(\mathrm{mi}^{2}\right)$ San Jacinto River Basin upstream from the reservoir (fig. 1). Most (2,692.4 $\mathrm{mi}^{2}$, about 97 percent) of the San Jacinto River Basin upstream from Lake Houston can be divided into western and eastern watersheds; the remaining $92.25 \mathrm{mi}^{2}$ (about 3 percent) of the basin consists of the drainage area downstream from the western and eastern watersheds surrounding Lake Houston. The western watersheds cover 1,746 $\mathrm{mi}^{2}$ (fig. 1) and represent about 63 percent of the San Jacinto River Basin; the eastern watersheds cover $946.4 \mathrm{mi}^{2}$ and represent about 34 percent of the basin. Hereinafter, the western and eastern watersheds are collectively referred to as the "San Jacinto River Basin."

Because of population growth, land use in the western watersheds has changed to include a relatively large amount of developed areas, whereas land use in the eastern watersheds has remained mostly undeveloped (fig. 1 in Beussink and Graham, 2011). Major tributaries in the western watersheds and the approximate percentage of the San Jacinto River
Basin that they drain are West Fork San Jacinto River (36 percent), Spring Creek (16 percent), and Cypress Creek (11 percent). Major tributaries in the eastern watersheds and the approximate percentage of the San Jacinto River Basin that they drain are East Fork San Jacinto River (14 percent), Caney Creek (8 percent), Peach Creek (6 percent), and Luce Bayou (6 percent). Land use in the immediately surrounding area of Lake Houston is a mix of developed and undeveloped areas (fig. 1 in Beussink and Graham, 2011). Six wastewatertreatment facilities contribute wastewater discharge to Lake Houston (Miertschin and Associates, 2007). More than 300 municipal wastewater discharges are permitted in the basin (Texas Commission on Environmental Quality, 2011).

The climate in the study area is classified as humid subtropical (Larkin and Bomar, 1983), characterized by cool, temperate winters and hot, humid summers. Air temperatures of 90 degrees Fahrenheit $\left({ }^{\circ} \mathrm{F}\right)$ or warmer are common from April through October. During 2005-09, annual rainfall ranged from approximately 41 to 65 inches (in.) at the meteorological station operated by the National Weather Service (NWS) at George Bush Intercontinental Airport near Houston (National Oceanic and Atmospheric Administration, 2012).

\section{Previous Studies}

Although the hydrodynamics of Lake Houston are not fully understood, previous investigators have gained some insights into water residence time and mixing in this reservoir. Theoretical water residence time in Lake Houston ranges from about 12 hours to 400 days (Liscum and East, 2000); annual mean water residence time during 2000-04 ranged from 24 to 176 days (Sneck-Fahrer and others, 2005). Storm runoff generally passes through the reservoir within 24 hours. During storm events, horizontal and vertical mixing is not complete for at least one-half the length of the reservoir (Matty and others, 1987; Kilson, 1992).

Since 1983, the USGS, in cooperation with the City of Houston, has collected water-quality and lake-elevation data for Lake Houston, water-quality and streamflow data for the major tributaries to Lake Houston (Lee and Rast, 1997; Liscum and others, 1999; Sneck-Fahrer and others, 2005; Beussink and Burnich, 2009), and has published water-quality assessments pertaining to Lake Houston and its tributaries. Liscum and East (2000) evaluated the possible effects on Lake Houston water quality from an interbasin transfer of water from the Trinity River. Beussink and Graham (2011) focused on water-quality constituents that affect the aesthetic quality of drinking water such as geosmin, 2-Methylisoborneol (MIB), and manganese. Lee and others (2012) developed regression models for selected constituent concentrations and loads of tributaries to the lake. Lake Houston displays longitudinal gradient characteristics, with larger nutrient concentrations, turbidity, and algal biomass in the riverine zone (upstream part of the reservoir) of the reservoir and smaller concentrations in the lacustrine zone (downstream part of the reservoir) near the dam (Conrad, 1986; Sneck-Fahrer and others, 2005). 


\section{Methods of Data Collection}

A comprehensive dataset, including lake elevations, streamflow, specific conductance, and water temperature, was compiled for 10 USGS data-collection sites and meteorological data were compiled from the NWS meteorological station at George Bush Intercontinental Airport near Houston (National Oceanic and Atmospheric Administration, 2012) (fig. 1, table 1). All of these data were used in development of the Lake Houston three-dimensional hydrodynamic model. Of the 10 USGS data-collection sites, 7 are streamflow-gaging stations, and 3 are reservoir stations. At five of the seven streamflow-gaging stations, only streamflow data were collected (table 1). At the other two streamflowgaging stations, specific conductance and water temperature data were collected in addition to streamflow (table 1). Lake elevation was measured at one of the reservoir stations, whereas specific conductance and water temperature were measured at the other two reservoir stations (table 1). The ArcGIS Watershed (Spatial Analyst) tool was used to create raster-delineated drainage basin areas (Esri, 2011).

\section{Lake Elevation}

Lake elevation was measured at USGS reservoir station 08072000 Lake Houston near Sheldon, Tex. (hereinafter referred to as the "Sheldon gage"), which is near the dam.
The Sheldon gage is satellite telemetered and transmits data at 15-minute intervals. Prior to October 1, 2009, the datum of the Sheldon gage was $0.70 \mathrm{ft}$ below the National Geodetic Vertical Datum of 1929; after October 1, 2009, the gage datum, unadjusted for land-surface subsidence $(2.77 \mathrm{ft}$ above current datum), was changed to the North American Vertical Datum 1988 (NAVD 88), which is the datum used for the three-dimensional hydrodynamic model.

\section{Streamflow}

Streamflow was continuously measured at the streamflow-gaging stations on the seven major tributaries to Lake Houston (table 1). Streamflow data were electronically recorded and transmitted by satellite from the seven USGS streamflow-gaging stations to a downlink site and then to the USGS Texas Water Science Center in Austin, Tex., where they were reviewed and finalized before being stored in the USGS National Water Information System (NWIS) database (http://waterdata.usgs.gov/tx/nwis/). Discharge measurements were periodically made to verify and modify a stage-discharge relation developed on the basis of streamflow measurements and the stage of the stream at the time of measurement (Rantz and others, 1982; Kennedy, 1984; Turnipseed and Sauer, 2010). These unique relations were used to compute a continuous record of streamflow (Kennedy, 1983) from the stage record at each site. Instantaneous stage and streamflow

Table 1. Data collected at U.S. Geological Survey (USGS) streamflow-gaging stations in the San Jacinto River Basin upstream from Lake Houston and at USGS reservoir stations in Lake Houston, near Houston, Texas, 2009 and 2010.

[USGS, U.S. Geological Survey; --, not applicable; $x$, data collected]

\begin{tabular}{|c|c|c|c|c|c|c|}
\hline $\begin{array}{l}\text { USGS station } \\
\text { number }\end{array}$ & USGS station name & Short name & $\begin{array}{c}\text { Stage } \\
\text { (lake } \\
\text { elevation) }\end{array}$ & Streamflow & $\begin{array}{c}\text { Specific } \\
\text { conductance }\end{array}$ & $\begin{array}{c}\text { Water } \\
\text { temperature }\end{array}$ \\
\hline \multicolumn{7}{|c|}{ Streamflow-gaging stations on tributaries to Lake Houston } \\
\hline 08068090 & $\begin{array}{l}\text { West Fork San Jacinto River above } \\
\text { Lake Houston near Porter, Tex. }\end{array}$ & $\begin{array}{r}\text { West Fork San } \\
\text { Jacinto gage }\end{array}$ & -- & $\mathrm{x}$ & -- & -- \\
\hline 08068500 & Spring Creek near Spring, Tex. & Spring Creek gage & -- & $\mathrm{x}$ & $\mathrm{x}$ & $\mathrm{x}$ \\
\hline 08070200 & $\begin{array}{l}\text { East Fork San Jacinto River near New } \\
\text { Caney, Tex. }\end{array}$ & $\begin{array}{l}\text { East Fork San } \\
\text { Jacinto gage }\end{array}$ & -- & $\mathrm{x}$ & $\mathrm{x}$ & $\mathrm{x}$ \\
\hline 08070500 & Caney Creek near Splendora, Tex. & Caney Creek gage & -- & $\mathrm{x}$ & -- & -- \\
\hline 08071000 & Peach Creek at Splendora, Tex. & Peach Creek gage & -- & $\mathrm{x}$ & -- & -- \\
\hline 08071280 & $\begin{array}{l}\text { Luce Bayou above Lake Houston near } \\
\text { Huffman, Tex. }\end{array}$ & Luce Bayou gage & -- & $\mathrm{x}$ & -- & -- \\
\hline 295826095082200 & $\begin{array}{l}\text { Lake Houston south Union Pacific } \\
\text { Railroad Bridge near Houston, Tex. }\end{array}$ & Site A & -- & -- & $\mathrm{x}$ & $\mathrm{x}$ \\
\hline 295554095093401 & $\begin{array}{l}\text { Lake Houston at mouth of Jack's Ditch } \\
\text { near Houston, Tex. }\end{array}$ & Site B & -- & -- & $\mathrm{x}$ & $\mathrm{x}$ \\
\hline
\end{tabular}


values are stored in the NWIS database (http://waterdata.usgs. gov/tx/nwis/).

\section{Specific Conductance and Water Temperature}

Specific conductance and water temperature were continuously monitored during 2009-10 at two stream locations and two lake locations in the study area (table 1). The two stream locations were USGS streamflow-gaging station 08068500 Spring Creek near Spring, Tex. (hereinafter the Spring Creek gage), and USGS streamflow-gaging station 08070200 East Fork San Jacinto River near New Caney, Tex. (hereinafter the East Fork San Jacinto gage). The two lake locations were USGS reservoir station 295826095082200 Lake Houston south Union Pacific Railroad Bridge near Houston, Tex. (site A), and USGS reservoir station 295554095093401 Lake Houston at mouth of Jack's Ditch near Houston, Tex. (site B).

A swinging well design was used for continuously monitoring specific conductance and water temperature at the Spring Creek and East Fork San Jacinto gages. Swinging wells respond to and move in the water column or "swing" in the direction of the force of the flowing water. The wells were constructed of schedule 80 polyvinyl-chloride pipes with holes in the bottom 3 -ft section, allowing water to pass through freely at the position where the multiparameter monitor is located inside the well. Each swinging well containing a multiparameter monitor was positioned near the centroid of flow in each stream.

At the two lake locations (sites A and B), floating platforms that recorded real-time water-quality data by using an auto-reel system for vertical profiling were used as described in Beussink and Burnich (2009). These platforms are fully automated and lower a multiparameter monitor to vertical depths of $1,6,12$, and $16 \mathrm{ft}$ at 15 -minute intervals. The multiparameter monitors were calibrated as described in the USGS "National Field Manual for the Collection of Water-Quality Data" (U.S. Geological Survey, variously dated). The multiparameter monitors were maintained and the resulting data records processed as outlined in Wagner and others (2006). The data from each multiparameter monitor are electronically recorded and transmitted by satellite to a downlink site and then to the USGS Texas Water Science Center in Austin. Specific conductance and water temperature data collected at 15-minute intervals were stored in the USGS NWIS database (http://waterdata.usgs.gov/tx/nwis/). Specific conductance was measured in microsiemens per centimeter at 25 degrees Celsius, and water temperature was measured in degrees Fahrenheit.

\section{Meteorological Data}

Meteorological data used in this report were recorded hourly at the NWS meteorological station at George Bush Intercontinental Airport near Houston (National Oceanic and
Atmospheric Administration, 2012). Meteorological data recorded at this site by the NWS are supplemented by solar radiation data recorded for the National Solar Radiation Database (NSRDB). A combined dataset of meteorological and solar data is stored in the NSRDB, which is overseen by the Department of Energy's National Renewable Energy Laboratory. The specific data that were obtained for use in this study are referred to in the NSRDB as the "solar and filled meteorological fields dataset" (National Renewable Energy Laboratory, 2012).

\section{Development of a Three-Dimensional Hydrodynamic Model}

The Environmental Fluid Dynamics Code (EFDC), a grid-based surface-water modeling package for simulating three-dimensional circulation, mass transport, sediments, and biogeochemical processes, was used to develop a threedimensional hydrodynamic model of Lake Houston. The EFDC was chosen to model the hydrodynamics of Lake Houston because it is an open source, publicly available software capable of accurately modeling the residence time of water in a lake. The EFDC model was originally developed at the Virginia Institute of Marine Science for estuarine and coastal applications (Hamrick, 1992). The U.S. Environmental Protection Agency (EPA) has continued to support its development in cooperation with Tetra Tech, Inc. (Hamrick, 2007), and the EFDC has been listed (along with other public domain surface-water models) as suitable for use in a variety of surface-water-related assessments (U.S. Environmental Protection Agency, 2015). The EFDC has been extensively tested, documented, and used in more than 100 surface-water studies (Ji, 2008).

Data characterizing the hydrologic conditions in Lake Houston and its contributing areas during 2009-10 were compiled to develop the EFDC model of Lake Houston. These data included lake elevation, inflows from the western and eastern watersheds, specific conductance, water temperature, and meteorological data.

\section{Lake Elevation in 2009 and 2010}

In 2009 and 2010, lake elevations in Lake Houston varied following patterns similar to the measured inflows (fig. 2). The maximum measured lake elevation was $44.49 \mathrm{ft}$ on April 29,2009 . The lake elevation then decreased during the early summer, declining to a low of $40.96 \mathrm{ft}$ on July 6, 2009. The lake elevation generally increased during the remainder of 2009, reaching an elevation of $43.73 \mathrm{ft}$ on October 31, 2009. Lake elevations generally decreased throughout most of 2010, declining to a minimum elevation of $40.97 \mathrm{ft}$ on November 1 , 2010 , and reached a maximum elevation of $43.30 \mathrm{ft}$ on July 3 , 2010. 

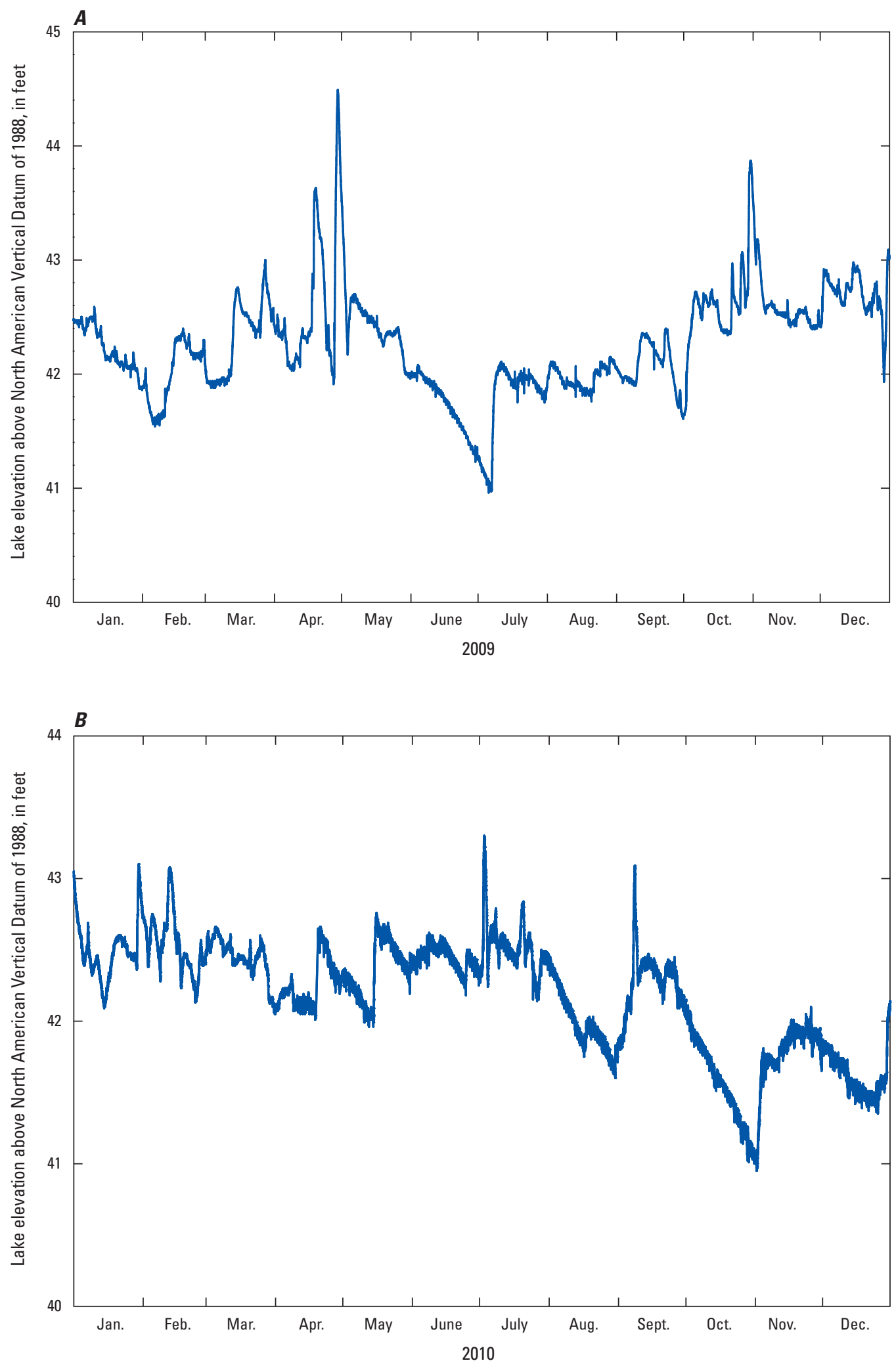

Figure 2. Lake elevations measured at U.S. Geological Survey reservoir station 08072000 Lake Houston near Sheldon, Texas, in A, 2009 and $B, 2010$. 


\section{Inflows to Lake Houston From the Western and Eastern Watersheds in 2009 and 2010}

The combined annual average streamflow measured at the streamflow-gaging stations on the seven major tributaries to Lake Houston (table 1) was approximately 1,300 cubic feet per second $\left(\mathrm{ft}^{3} / \mathrm{s}\right.$ ), in 2009 and 2010 (table 2). During 2009 and 2010, streamflow from the western watersheds (West Fork San Jacinto River, Spring Creek, and Cypress Creek) composed approximately 70 percent of the total inflows to Lake Houston, with the remaining coming from the eastern watersheds (East Fork San Jacinto River, Caney Creek, Peach Creek, and Luce Bayou). Whereas the combined annual average streamflow amounts from the seven major tributaries in 2009 and 2010 were similar, the magnitudes of individual storm events were different. During 2009, there were three storm events (April 19-20, April 28-29, and October 30-31), for which the combined inflows exceeded 10,000 and 7,000 ft $\mathrm{ft}^{3} / \mathrm{s}$ from the western and eastern watersheds, respectively. In 2009, the maximum combined inflow rate for the western watersheds was $38,000 \mathrm{ft}^{3} / \mathrm{s}$ on April 28, 2009, whereas the maximum combined inflow rate for the eastern watersheds was $12,000 \mathrm{ft}^{3} / \mathrm{s}$ on April 20, 2009 (fig. 3A). During 2010, there were only two storm events that generated inflows of more than $10,000 \mathrm{ft}^{3} / \mathrm{s}$ for the western watersheds or more than $3,500 \mathrm{ft}^{3} / \mathrm{s}$ for the eastern watersheds. In 2010, the maximum combined inflow rate for the western watersheds was 12,000 ft $\mathrm{ft}^{3} / \mathrm{s}$ on July 2, 2010, whereas the maximum combined inflow rate for the eastern watersheds was 5,200 ft $\mathrm{ft}^{3} / \mathrm{s}$ on February 13, 2010 (fig. 3B).

\section{Specific Conductance and Water Temperature in 2009 and 2010}

In 2009 and 2010, specific conductance and water temperature data were collected from one tributary to Lake
Houston representing the western watersheds (Spring Creek) and from one tributary representing the eastern watersheds (East Fork San Jacinto River) (table 1). Specific conductance, which is an indicator of ion concentration (Hem, 1985), followed the same patterns in 2009 and 2010 observed in previous studies for nutrients, suspended solids, and other water-quality constituents. In general, larger loads of nutrients, suspended solids, and other water-quality constituents are contributed to Lake Houston from tributaries in the western watersheds than from tributaries in the eastern watersheds, reflecting the differences in land use in the watersheds (Liscum and others, 1999; Van Metre and Sneck-Fahrer, 2002; Sneck-Fahrer and others, 2005). In 2009 and 2010, the specific conductance measured at the Spring Creek gage used to represent the western watersheds was generally higher and more variable than the specific conductance measured at the East Fork San Jacinto gage used to represent the eastern watersheds (fig. 4).

The water temperature patterns throughout the year at the Spring Creek and East Fork San Jacinto gages were similar, with slightly warmer temperatures in Spring Creek compared to the East Fork San Jacinto River, a difference that was most pronounced in the summer months (fig. 5). The maximum water temperatures recorded in 2009 were $94.1^{\circ} \mathrm{F}$ and $92.5^{\circ} \mathrm{F}$ in Spring Creek and the East Fork San Jacinto River on June 28 and on June 29, respectively. The minimum 2009 water temperatures recorded in Spring Creek and the East Fork San Jacinto River were $47.1^{\circ} \mathrm{F}$ and $46.4^{\circ} \mathrm{F}$ on December 28 and on December 29, respectively. During 2010 the maximum water temperature recorded at Spring Creek was $96.3^{\circ} \mathrm{F}$ on August 5, and the minimum water temperature recorded was $39.2^{\circ} \mathrm{F}$ on January 10. For the East Fork San Jacinto River, the maximum water temperature recorded during 2010 was $90.5^{\circ} \mathrm{F}$ on August 15, and the minimum water temperature recorded was $38.8^{\circ} \mathrm{F}$ on January 11 .

Table 2. Average annual inflow for each of the tributaries to Lake Houston, near Houston, Texas, in 2009 and 2010.

[USGS, U.S. Geological Survey; $\mathrm{ft}^{3} / \mathrm{s}$, cubic foot per second]

\begin{tabular}{|c|c|c|c|c|}
\hline $\begin{array}{l}\text { USGS } \\
\text { station } \\
\text { number }\end{array}$ & USGS station name & Short name & $\begin{array}{c}\text { Average } \\
\text { annual } \\
\text { inflow, } 2009 \\
\left(\mathrm{ft}^{3} / \mathrm{s}\right)\end{array}$ & $\begin{array}{c}\text { Average } \\
\text { annual } \\
\text { inflow, 2010 } \\
\left(\mathrm{ft}^{3} / \mathrm{s}\right)\end{array}$ \\
\hline 08068090 & West Fork San Jacinto River above Lake Houston near Porter, Tex. & West Fork San Jacinto gage & 345.2 & 418.6 \\
\hline 08068500 & Spring Creek near Spring, Tex. & Spring Creek gage & 293.2 & 290.2 \\
\hline 08070500 & Caney Creek near Splendora, Tex. & Caney Creek gage & 59.6 & 66.3 \\
\hline 08071000 & Peach Creek at Splendora, Tex. & Peach Creek gage & 71.1 & 73.7 \\
\hline 08071280 & Luce Bayou above Lake Houston near Huffman, Tex. & Luce Bayou gage & 110.8 & 55.4 \\
\hline
\end{tabular}



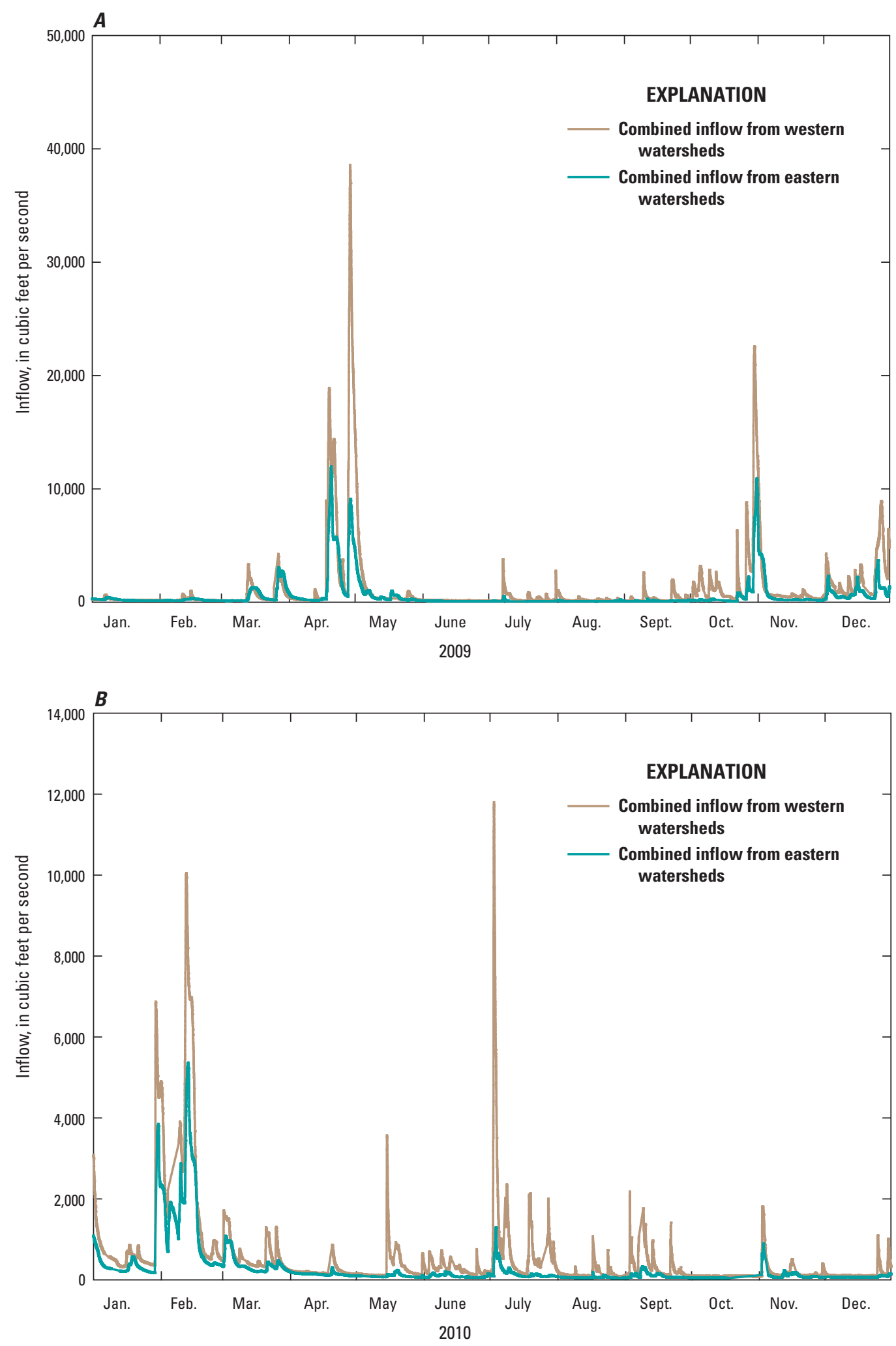

Figure 3. Combined inflow from the western and eastern watersheds to Lake Houston, near Houston, Texas, in A, 2009 and B, 2010. 

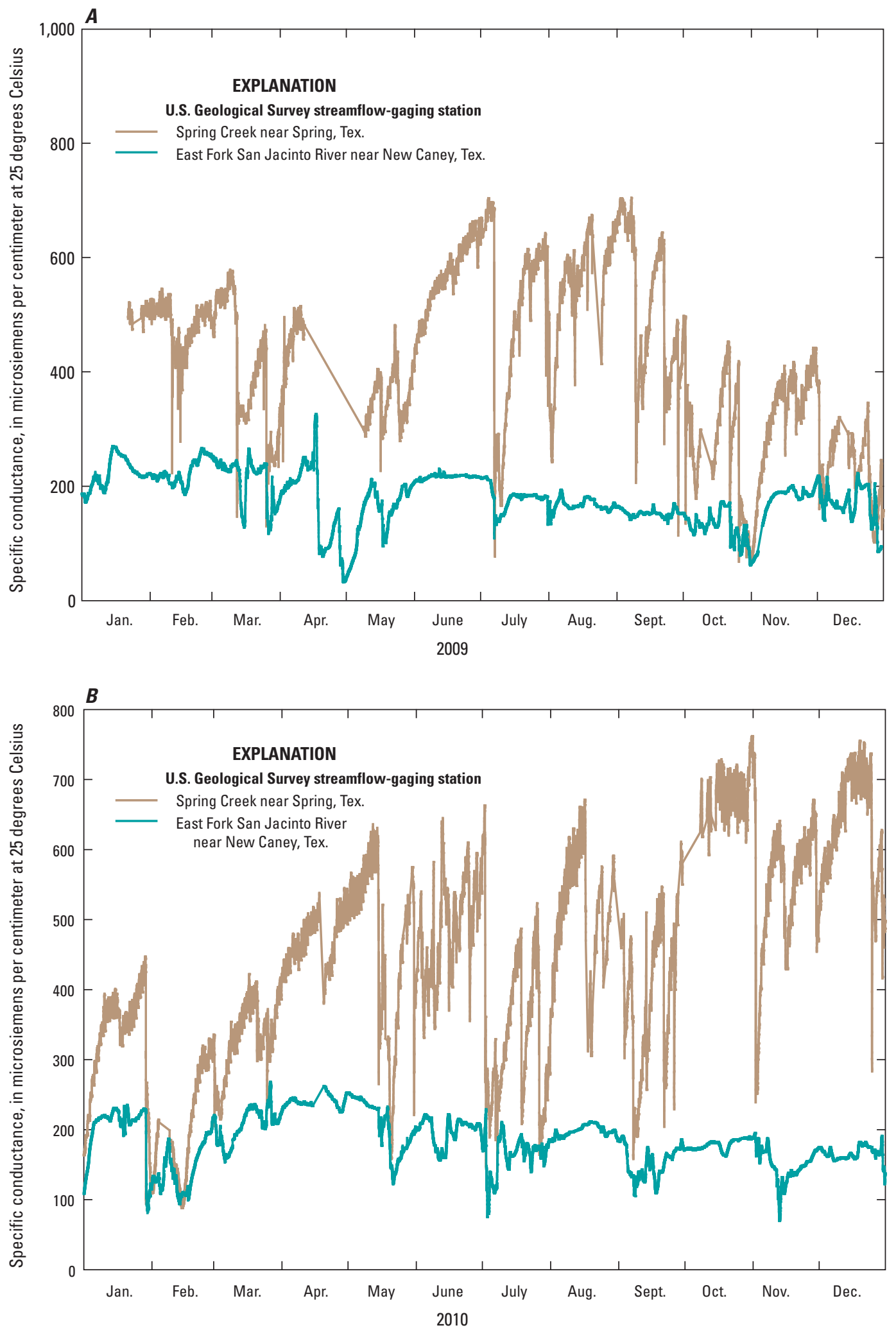

Figure 4. Specific conductance measured at U.S. Geological Survey streamflow-gaging stations 08068500 Spring Creek near Spring, Texas, and 08070200 East Fork San Jacinto River near New Caney, Tex., in A, 2009 and B, 2010. 

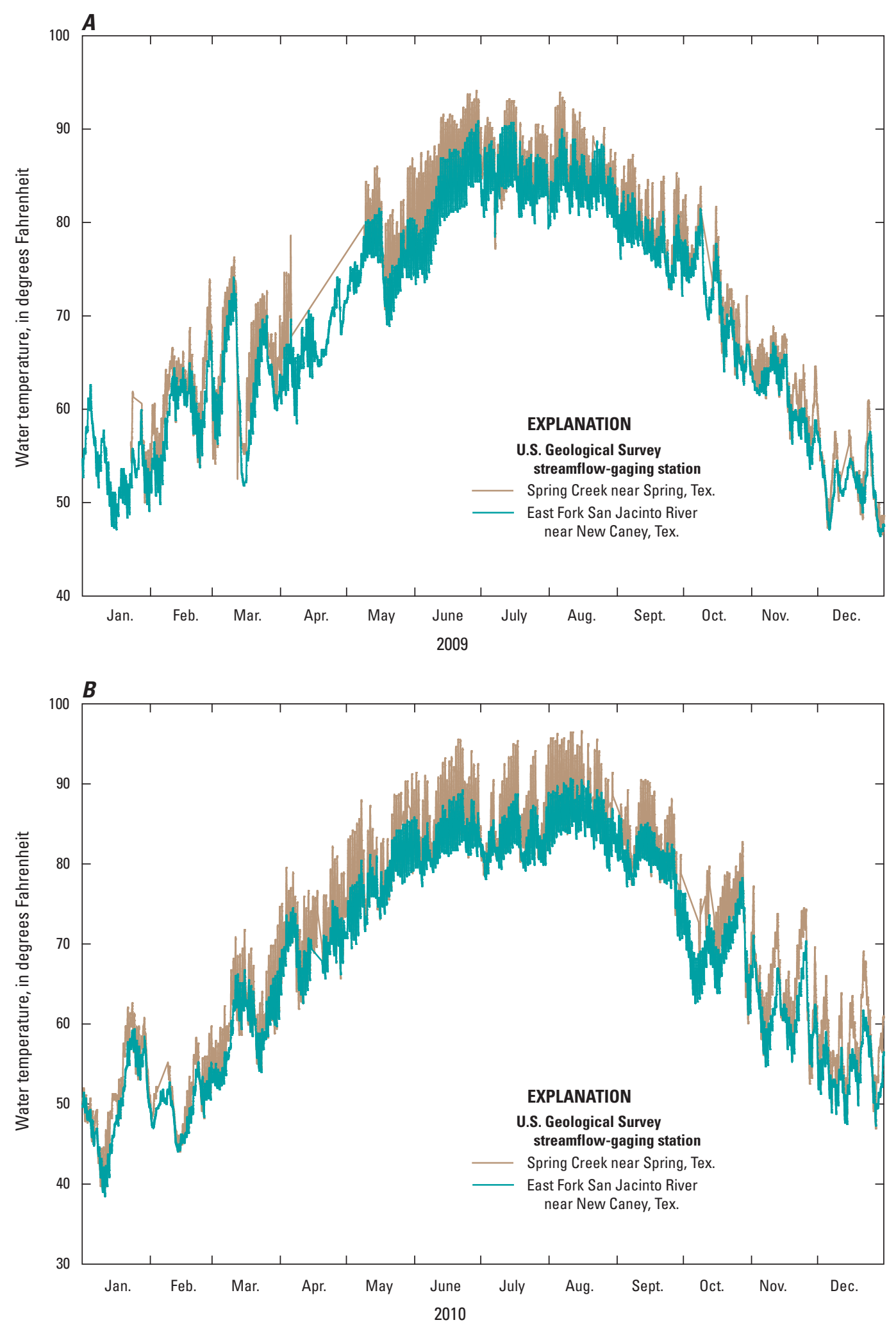

Figure 5. Water temperature measured at U.S. Geological Survey streamflow-gaging stations 08068500 Spring Creek near Spring, Texas, and 08070200 East Fork San Jacinto River near New Caney, Tex., in A, 2009 and B, 2010. 
Specific conductance and water temperature data were also collected at sites A and B in Lake Houston (table 1). In 2009, specific conductance and water temperature were measured at sites A and B at depths of $1,6,12$, and $16 \mathrm{ft}$. In 2010, specific conductance and water temperature data were only collected at a depth of $1 \mathrm{ft}$ at site A, whereas at site $\mathrm{B}$ these water-quality data were once again collected at depths of 1, 6, 12, and $16 \mathrm{ft}$. Where measured, the vertical distribution of specific conductance values was relatively uniform. A slight horizontal gradient in specific conductance was found between sites A and B, with slightly higher values that tended to decrease more at site A during runoff events (fig. 3) compared to site B (fig. 6). The horizontal stratification can be attributed to the location of site A, which is closer to the confluences of the seven major tributaries to the lake compared to site $\mathrm{B}$, which is closer to the dam that impounds the lake. The differences in their locations in the lake means that inflows arrive earlier at site $\mathrm{A}$ and have less time to mix with the existing lake water compared to site B. Where water temperature was measured at all four depths, a slight thermal stratification was observed during the cooler months of November through March; an example of this thermal stratification is provided by using the data collected for site B (fig. 7). This stratification became more pronounced during the warmer months of April through October. The difference between the 1-ft depth and the 16-ft depth can be less than $2{ }^{\circ} \mathrm{F}$ in the winter and as much as $10^{\circ} \mathrm{F}$ in the summer (fig. 7). There was little to no difference, however, horizontally in the thermal stratification in water temperature observed at sites A and $\mathrm{B}$.

\section{Meteorological Data in 2009 and 2010}

Hourly values for selected metrological data from 2009 and 2010 (dry bulb temperature [air temperature], relative humidity, air pressure, precipitation, cloud cover, wind speed, and wind direction) were measured at the NWS meteorological station at George Bush Intercontinental Airport during 2009-10. The prevailing wind direction varies considerably (fig. 8), with southerly winds prevailing during the spring and summer and northerly winds prevailing in the winter (Larkin and Bomar, 1983). Southerly winds are opposite to the longitudinal axis of flow in the lake.

The total annual rainfall measured at the NWS meteorological station at George Bush Intercontinental Airport was 46.9 and $42.9 \mathrm{in}$. during 2009 and 2010, respectively (National Oceanic and Atmospheric Administration, 2012). Although the overall magnitudes of the total annual rainfall during 2009 and 2010 were similar, the rain fell more sporadically and often at a higher intensity in 2010 compared to 2009 . The maximum hourly rainfall rate for 2009 was approximately $1 \mathrm{inch}$ per hour (in/h), whereas the maximum hourly rainfall rate for 2010 was approximately double at approximately $2 \mathrm{in} / \mathrm{h}$ (fig. 9). The pattern of more sporadic but higher intensity rainfall in 2010 compared to 2009 may have had some effect on the temperature and specific conductance in the upper layer of the lake.

\section{Model Description and Inputs}

Setup of the Lake Houston EFDC model required six types of boundary condition data, which may be applied to either individual boundary grid cells or the grid cells of the entire model domain and are contained in their own individual files (table 3 ). The six types of boundary condition data are (1) bathymetric data, (2) flow (inflows and outflows), (3) salinity, (4) water temperature, (5) meteorological, and (6) hydraulic structure (the shape and dimensions of the dam impounding Lake Houston). Each of these datasets was compiled or computed as needed, checked for erroneous or missing data values, and then input to the EFDC by using EFDC Explorer, a graphical user interface developed for the EFDC (Dynamic Solutions, LLC, 2015).

The bathymetric data, used to describe the bottom surface for the lake, were obtained from a 1994 hydrographic survey of Lake Houston by the Texas Water Development Board (Texas Water Development Board, 2012) and are stored in the dxdy.inp file (table 3 ). The boundary condition cells that were used in the Lake Houston EFDC model include inflow cells and outflow cells (outflows are through hydraulic structure cells and pump cells) (fig. 10, table 3 ). Inflow cells require data characterizing the inflows to Lake Houston, as well as salinity and water temperature data for Lake Houston. The outflow cells only require the outflows from Lake Houston as an input since the outflow salinity and water temperature are computed by using equations built into the EFDC model. Inflow and outflow data are stored in the qser.inp file (table 3), salinity data are stored in the sser.inp file, and water temperature data are stored in the tser.inp file (table 3). Meteorological data are applied to the entire model domain and are stored in the atmospheric forcing time-series file (aser.inp) (table 3). Hydraulic structure data, stored in the qctl.inp file, were based on a rating curve normalized for the length of the San Jacinto Dam that was developed to estimate outflows over the San Jacinto Dam from lake elevations (table 3). Additional input files (efdc.inp, cell.inp, cellt.inp, lxly.inp) provide a range of specific functions necessary in the model (table 3). 

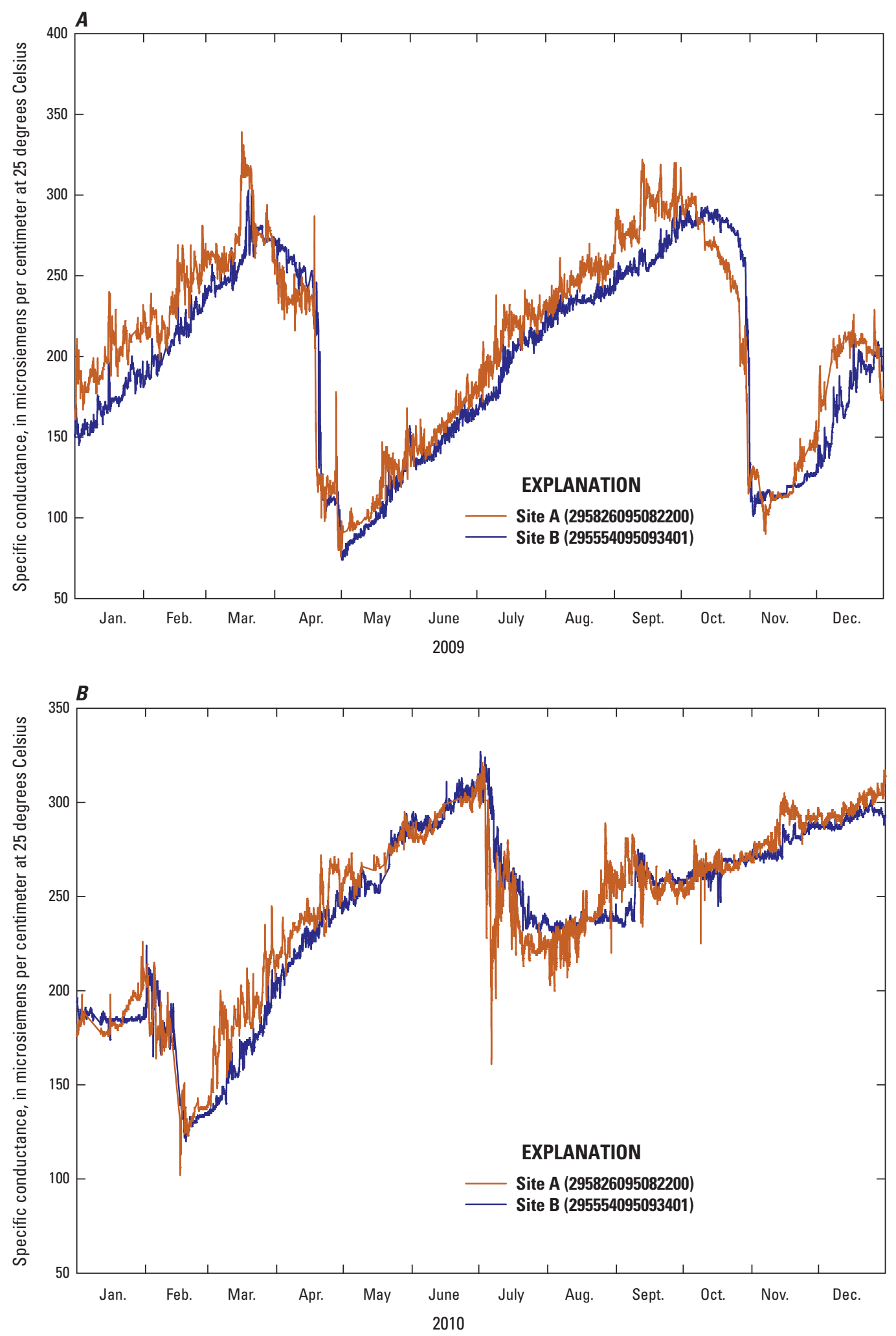

Figure 6. Specific conductance measured at a depth of 12 feet at U.S. Geological Survey reservoir stations 295826095082200 Lake Houston south Union Pacific Railroad Bridge near Houston, Texas (site A), and 295554095093401 Lake Houston at mouth of Jack's Ditch near Houston, Tex. (site $B$ ), in $A, 2009$ and $B, 2010$. 


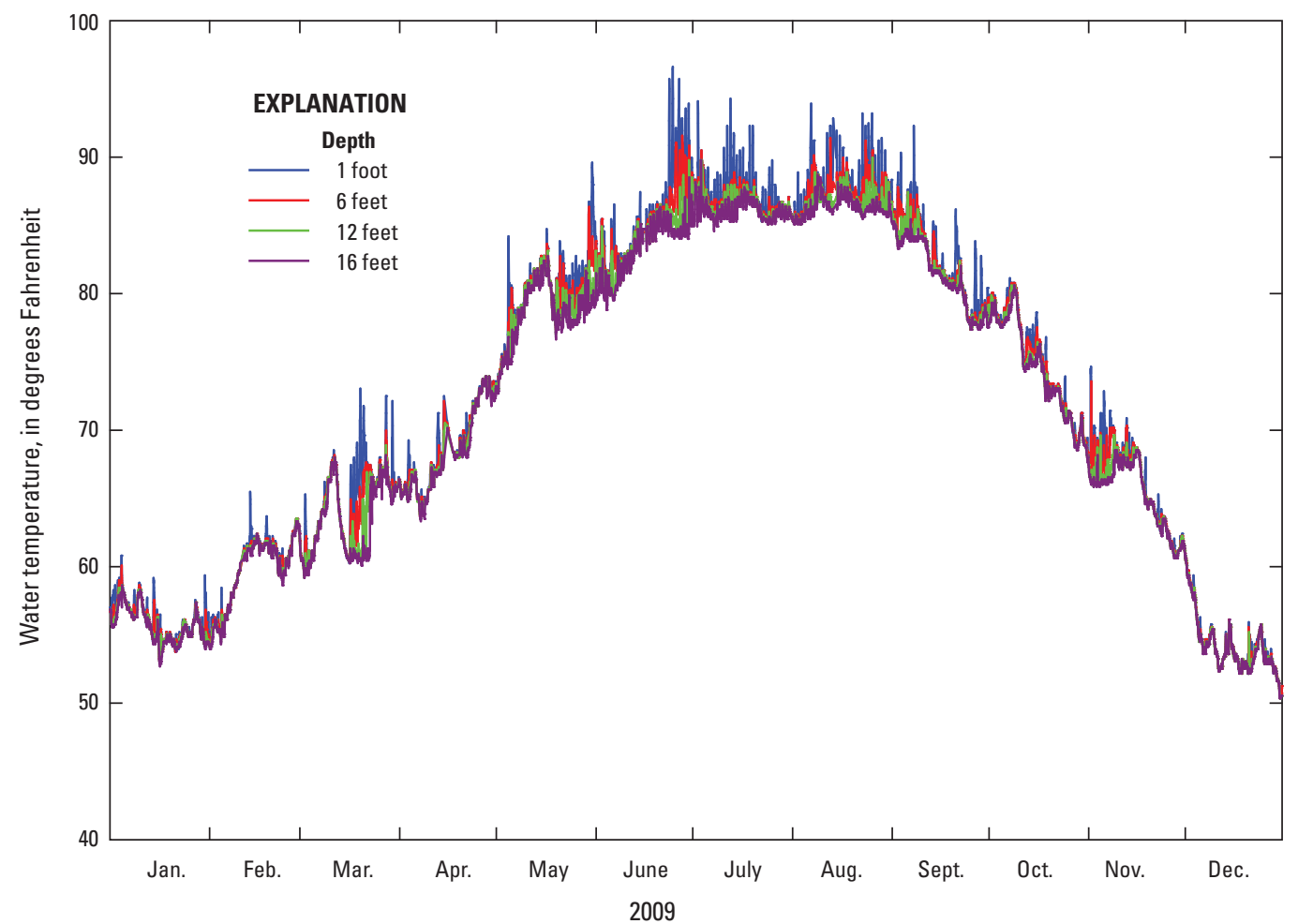

Figure 7. Water temperature measured at 1-, 6-, 12-, and 16-foot depths at U.S. Geological Survey reservoir station 295554095093401 Lake Houston at mouth of Jack's Ditch near Houston, Texas (site B), 2009. 
$\boldsymbol{A}$

\section{EXPLANATION}

Wind speed, in feet per second, for 2009Wind direction is shown in degrees $\left({ }^{\circ}\right)$ from true north. One symbol may represent more than one value

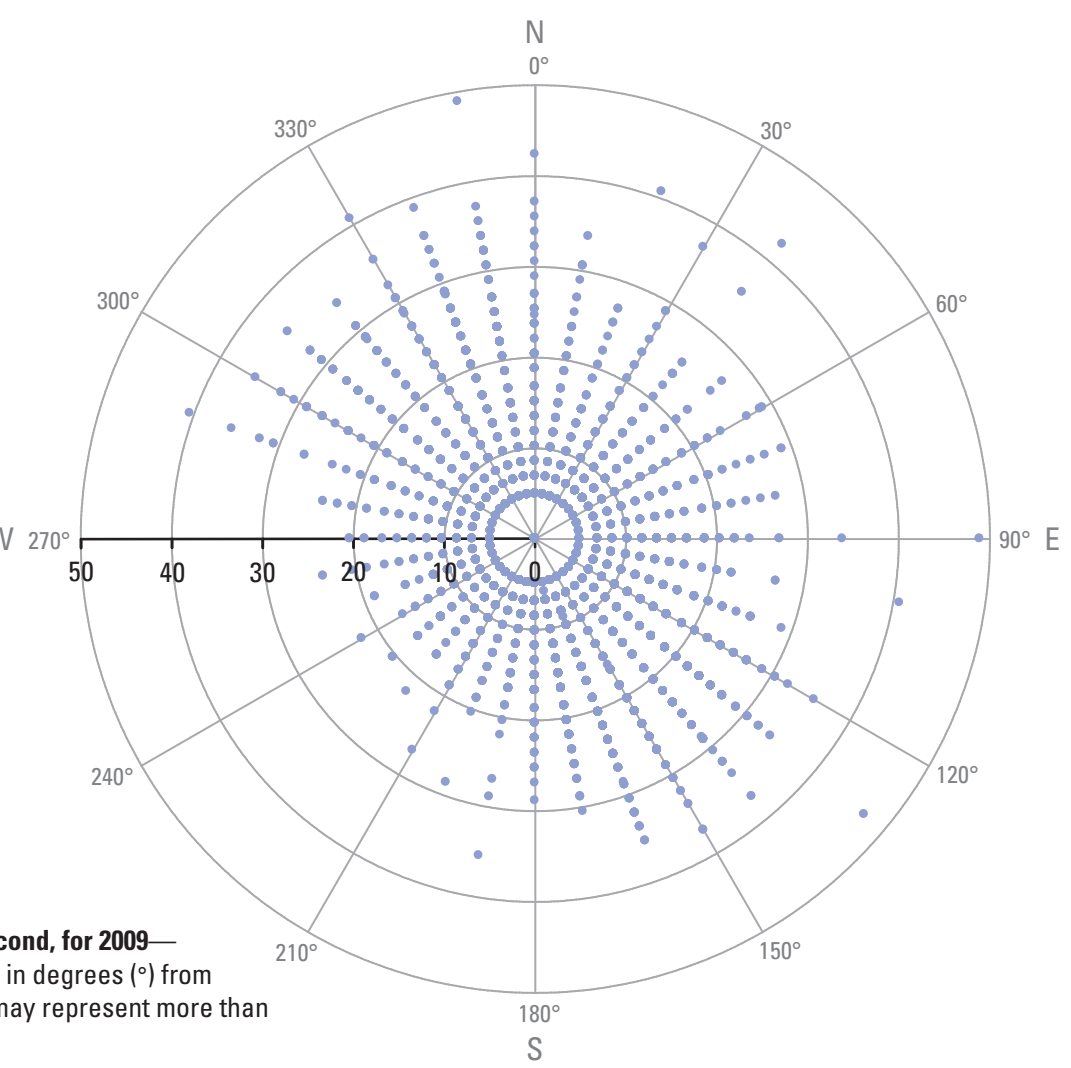

B

\section{EXPLANATION}

Wind speed, in feet per second, for 2010 Wind direction is shown in degrees $\left({ }^{\circ}\right)$ from true north. One symbol may represent more than one value

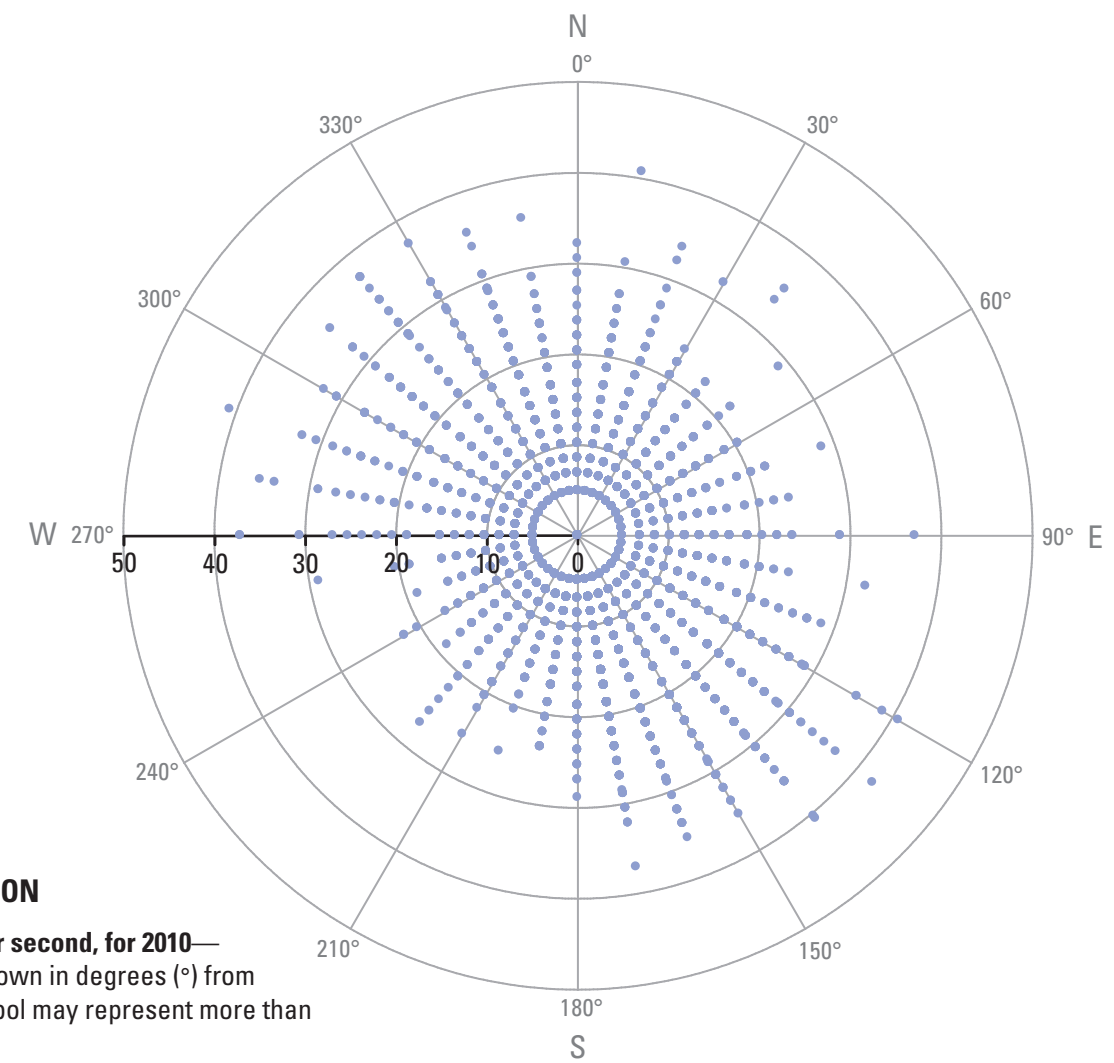

Figure 8. Wind-rose graphs depicting hourly wind speed and direction values measured at the National Weather Service meteorological station at George Bush Intercontinental Airport near Houston, Texas, in A, 2009 and B, 2010. 

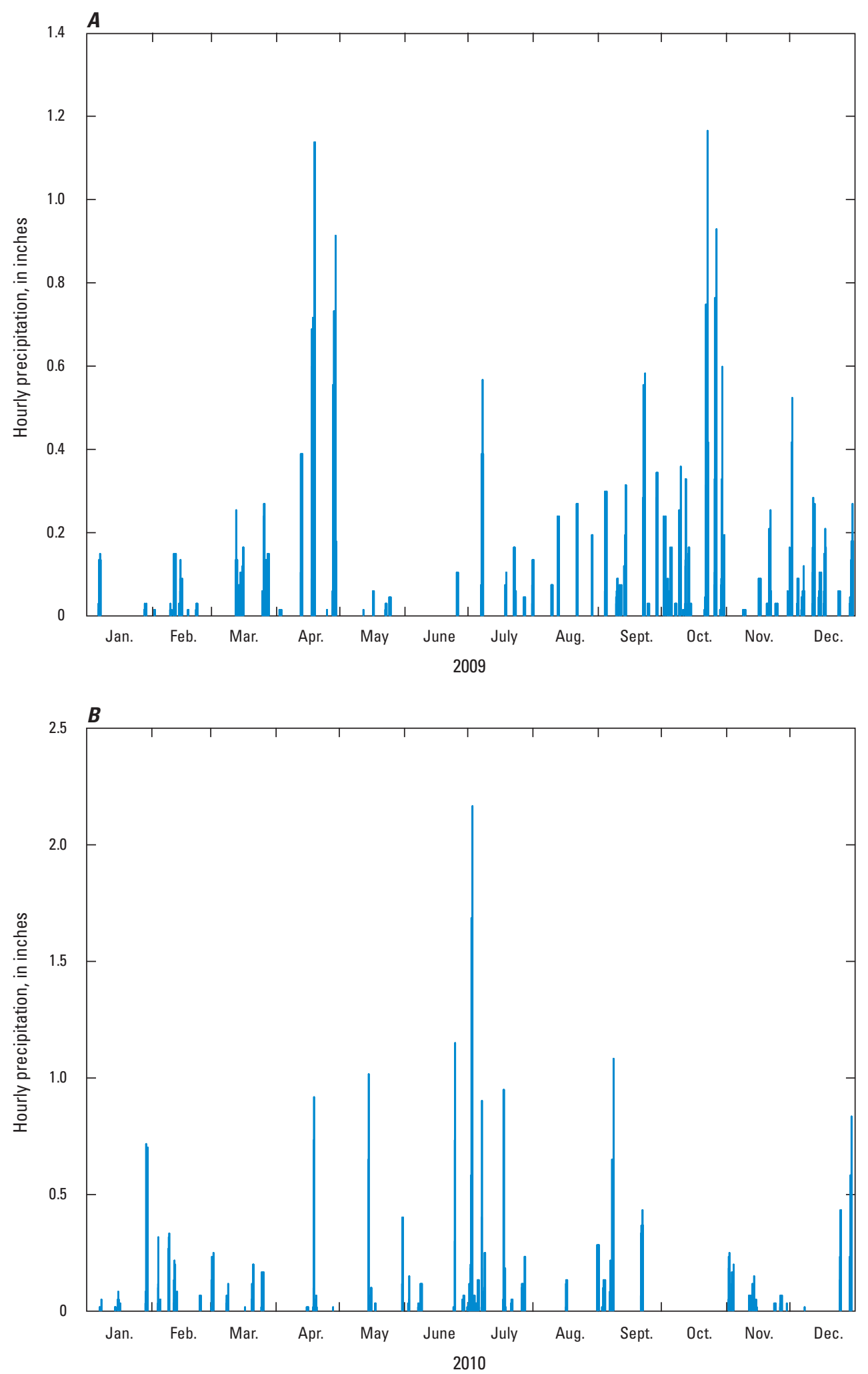

Figure 9. Hourly precipitation measured at the National Weather Service meteorological station at George Bush Intercontinental Airport near Houston, Texas, in A, 2009 and B, 2010. 
Table 3. Model input files for the Environmental Fluid Dynamics Code (EFDC) hydrodynamic model of Lake Houston, near Houston, Texas.

[--, not applicable]

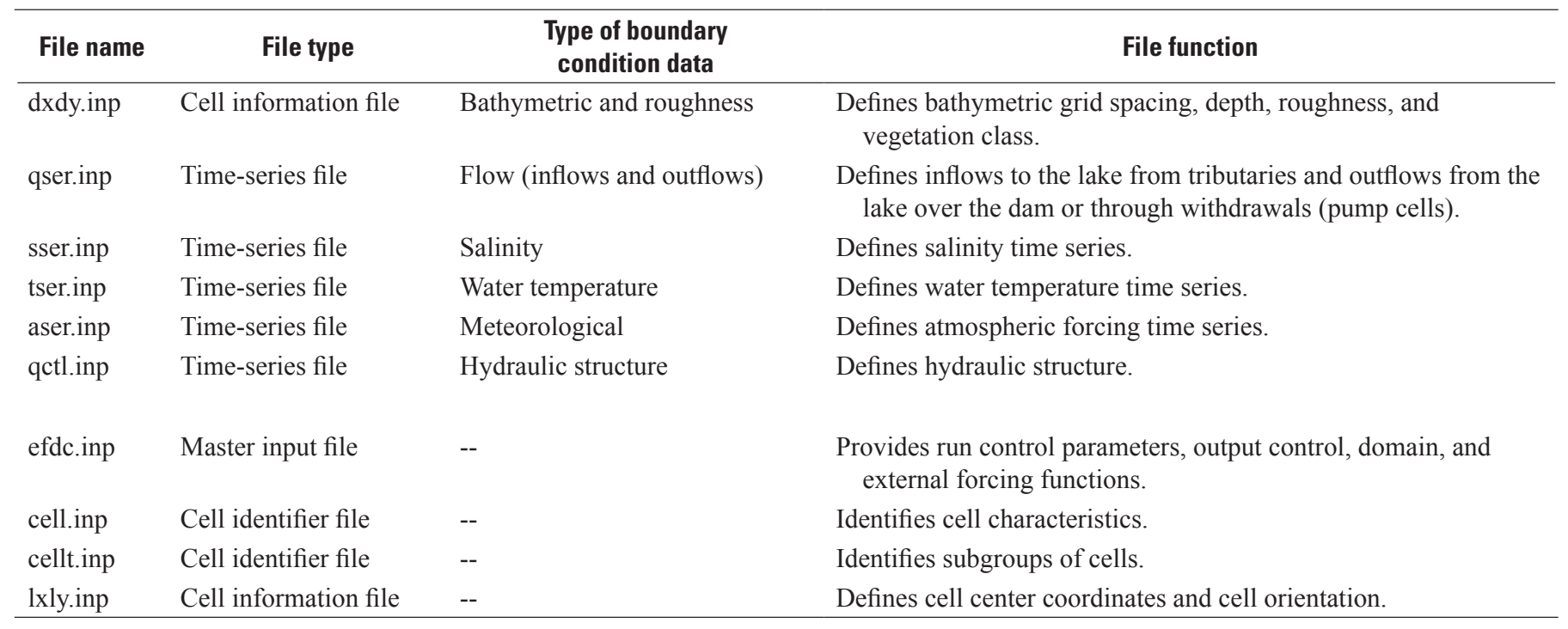

Lake-specific model parameters that govern friction, heat transfer, advection, and diffusion were used in the dynamically coupled transport equations for turbulent kinetic energy, turbulent length scale, salinity, and water temperature (Hamrick, 2007). These model parameters are used by the EFDC and stored in different input (.inp) files (table 3).

Friction is governed by model parameter roughness, which pertains to effective bottom roughness of the lake and is used in internal model calculations to achieve agreement with lake elevations and velocities; roughness is stored in the dxdy. inp file (table 3). The roughness used in the calibrated Lake Houston hydrodynamic model ranges from $0.07-0.20 \mathrm{ft}$. These values vary longitudinally along the lake with roughness values of $0.07 \mathrm{ft}$ near the tail waters and inflow tributaries to $0.20 \mathrm{ft}$ near the dam.

Data stored in the atmospheric forcing time-series file (aser.inp file) (table 3) include atmospheric pressure, air temperature, relative humidity, rainfall, and solar radiation, which are the atmospheric forcing variables that govern heat transfer. Heat transfer is used in internal model calculations for simulating water temperature in the lake. The initial bed temperature for the calibrated Lake Houston hydrodynamic model was set to $68^{\circ} \mathrm{F}$, which was nearly identical to the initial bed temperature used by Liscum and East (2000).

Solar radiation was internally computed by using latitude and percent cloud cover.

There are multiple advection schemes that can be used in the EFDC that are set in the efdc.inp file (table 3). In the calibrated Lake Houston hydrodynamic model, upwind difference momentum advection was used with a standard turbulent intensity scheme. This scheme was chosen because of the particular hydrodynamics measured in the lake, as well as the external wind forcing.
In the EFDC, diffusion is modeled as vertical diffusion, which is computed implicitly, and horizontal diffusion, which is computed explicitly (Hamrick, 2007). The EFDC code that activates calculation of the horizontal diffusion component is stored in the efdc.inp file (table 3). For the calibrated Lake Houston hydrodynamic model the two parameters that govern diffusion were set to use constant horizontal momentum through the model calibration process: mass diffusivity (set to 1.08 square feet per second $\left[\mathrm{ft}^{2} / \mathrm{s}\right]$ ) and kinematic viscosity (set to $\left.1.08 \mathrm{ft}^{2} / \mathrm{s}\right)$.

\section{Model Grid}

Bathymetric data were obtained from a 1994 hydrographic survey of Lake Houston (Texas Water Development Board, 2012). The bathymetric survey points were interpolated in ArcGIS (Esri, 2015) to create a continuous bathymetric surface for the bottom of Lake Houston. A bathymetric surface averaged over each of the modeled grid cells in the model domain was obtained from Dynamic Solutions, LLC, and used as the bottom elevation (bathymetric data) inputs to the Lake Houston EFDC model (Andy Stoddard, Dynamic Solutions, LLC, written commun., 2010). Bathymetric data are stored in the dxdy.inp file (table 3).

To accurately describe Lake Houston and its volume, a curvilinear horizontal grid was developed by Dynamic Solutions, LLC. After testing, a total of 1,632 horizontal grids were used in the model domain. The Lake Houston EFDC model grids were then configured with eight vertical layers representing one-eighth of the total water depth in order to simulate the vertical stratification of Lake Houston. 


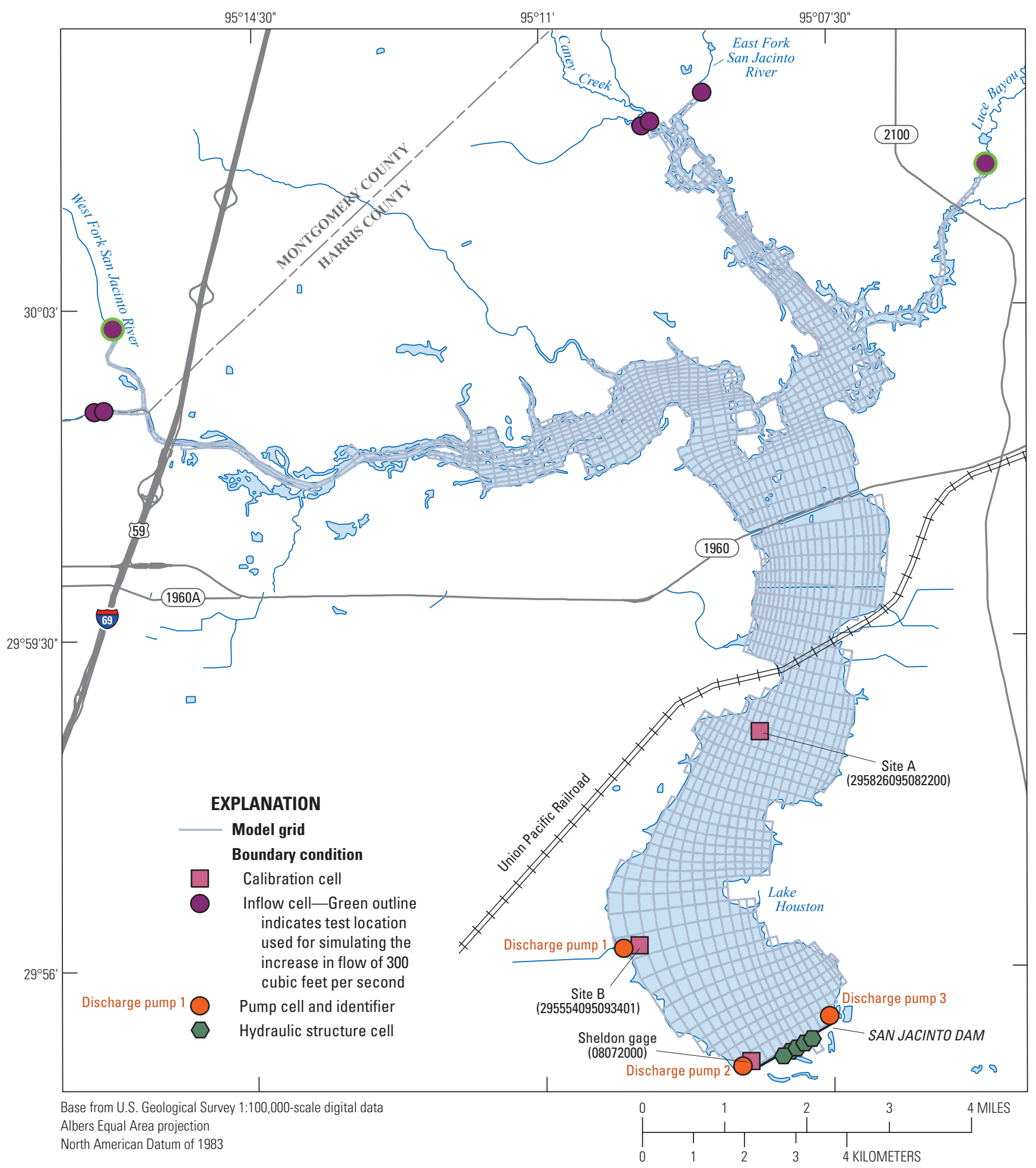

Figure 10. Conceptual layout of Lake Houston Environmental Fluid Dynamics Code (EFDC) model with grid and boundary condition cells for Lake Houston, near Houston, Texas. 


\section{Modeled Streamflow}

The EFDC uses time-series streamflow data as one of its input datasets. Streamflow data represented in the Lake Houston EFDC model consisted of inflows to Lake Houston from tributaries and outflows from Lake Houston in the form of withdrawals pumped from the lake and water going over the spillway of the dam. The watershed areas for Lake Houston and for each of the seven major tributaries (fig. 1, table 1) were delineated by using elevation data downloaded from the National Elevation Dataset (National Digital Elevation Program, 2004) and ArcGIS (Esri, 2015). Each of the seven major tributary watersheds was delineated into two areas - an area represented by the USGS streamflow-gaging station in that watershed (gaged inflows) and an area that was not included in the USGS flow calculations (ungaged inflows) (fig. 11, table 4). A simple variation on the rational method first proposed by Kuichling (1889) and described in Chow and others (1988) was used to develop corresponding lake inflows that capture the spatial distribution of ungaged inflows to Lake Houston. The gaged watershed area for each tributary was compared to the total watershed area of that tributary to calculate the ratio of ungaged to gaged areas by using equation 1 :

$$
R_{w}=\frac{A_{u w}}{A_{g w}},
$$

where

$$
\begin{gathered}
R_{w} \quad \begin{array}{c}
\text { is the ratio of the ungaged area to the gaged } \\
\text { tributary watershed area for a given } \\
\text { watershed (unitless), }
\end{array} \\
A_{u w} \quad \text { is the ungaged tributary watershed area in } \\
\text { acres, and } \\
A_{g w} \quad \text { is the gaged tributary watershed area in acres. }
\end{gathered}
$$

A ratio of ungaged watershed area to gaged watershed area around Lake Houston that did not correspond to the drainage area of any of the tributaries was computed by using equation 2:

$$
R_{l}=\frac{A_{u l}}{A_{g l}},
$$

where

$$
\begin{gathered}
R_{l} \quad \text { is the ratio of the ungaged area to the gaged } \\
\text { lake watershed area for the lake (unitless), } \\
A_{u l} \quad \text { is the ungaged lake watershed area in acres, } \\
\text { and } \\
A_{g l} \quad \text { is the gaged lake watershed area in acres. }
\end{gathered}
$$

The corresponding ratio of gaged to ungaged tributary watershed area and the additional ungaged lake watershed area ratio were then used to create a scalar factor from the streamflow rates at each of the seven gaged tributaries. This scalar factor $(K)$ is computed by using equation 3 :

$$
K=\left(1+R_{w}+R_{l}\right)
$$

The gaged streamflow rate for each of the contributing watersheds was then multiplied by its corresponding scalar factor to calculate total contributing flow into Lake Houston from that watershed (equation 4, table 4):

$$
Q_{t w}=Q_{g w} \times K
$$

where

$$
\begin{aligned}
& Q_{t w} \quad \text { is the total watershed contributing flow into } \\
& \text { Lake Houston, and } \\
& Q_{g w} \quad \text { is the gaged streamflow from that watershed. }
\end{aligned}
$$

There are three time-series outflow datasets used for populating the pump cells in the Lake Houston EFDC model (for the purposes of this report, the locations where these data were obtained are referred to as discharge pumps 1,2, and $3)$. The data for all three pumps were provided by the City of Houston (Joey Eickhoff, written commun., 2012). The data for discharge pumps 1 and 2 were provided at a daily time step. The data for discharge pump 3 were provided at a monthly time step and adjusted to a daily time step.

The outflow from Lake Houston at the San Jacinto Dam was simulated by using a hydraulic structure boundary condition that allows the EFDC model to simulate flow out of a cell on the basis of an existing rating-curve relation between stage and discharge. Outflow from Lake Houston over the San Jacinto Dam spillway is estimated from the rating curve at the Sheldon gage that is used to characterize the relation between lake elevation and outflow. This rating curve accounts for lake elevations ranging from 41.6 to $49.8 \mathrm{ft}$ and outflows ranging from 0 to $370,000 \mathrm{ft}^{3} / \mathrm{s}$. For modeling purposes, the outflow from the lake computed from the rating curve was divided by the length of the dam, redistributed according to the length of each of the five applicable cells on the model grid, and then used to specify the outflow from the Lake Houston EFDC model for simulated lake water levels.

\section{Specific Conductance and Water Temperature}

Salinity and water temperature were chosen for use in model calibration because they are good indicators of the overall hydrodynamic behavior of lakes. Salinity is a natural tracer that can be used for evaluating conservative mass transport, whereas temperature can be used to evaluate seasonal vertical structure, mixing potential, and energy balance (Jin and others, 2000).

The EFDC model also requires salinity values as an input dataset for all inflows to Lake Houston. Salinity values were computed from specific conductance measured at the sampling locations representing the gaged inflows from the Spring Creek and East Fork San Jacinto River watersheds (table 1). Salinity in parts per thousand was computed from measured specific conductance by using techniques described in Wagner and others (2006, p. 36) and Schemel (2001); Lewis (1980) provided an overview of the advantages of determining salinity from specific conductance compared to other methods. 


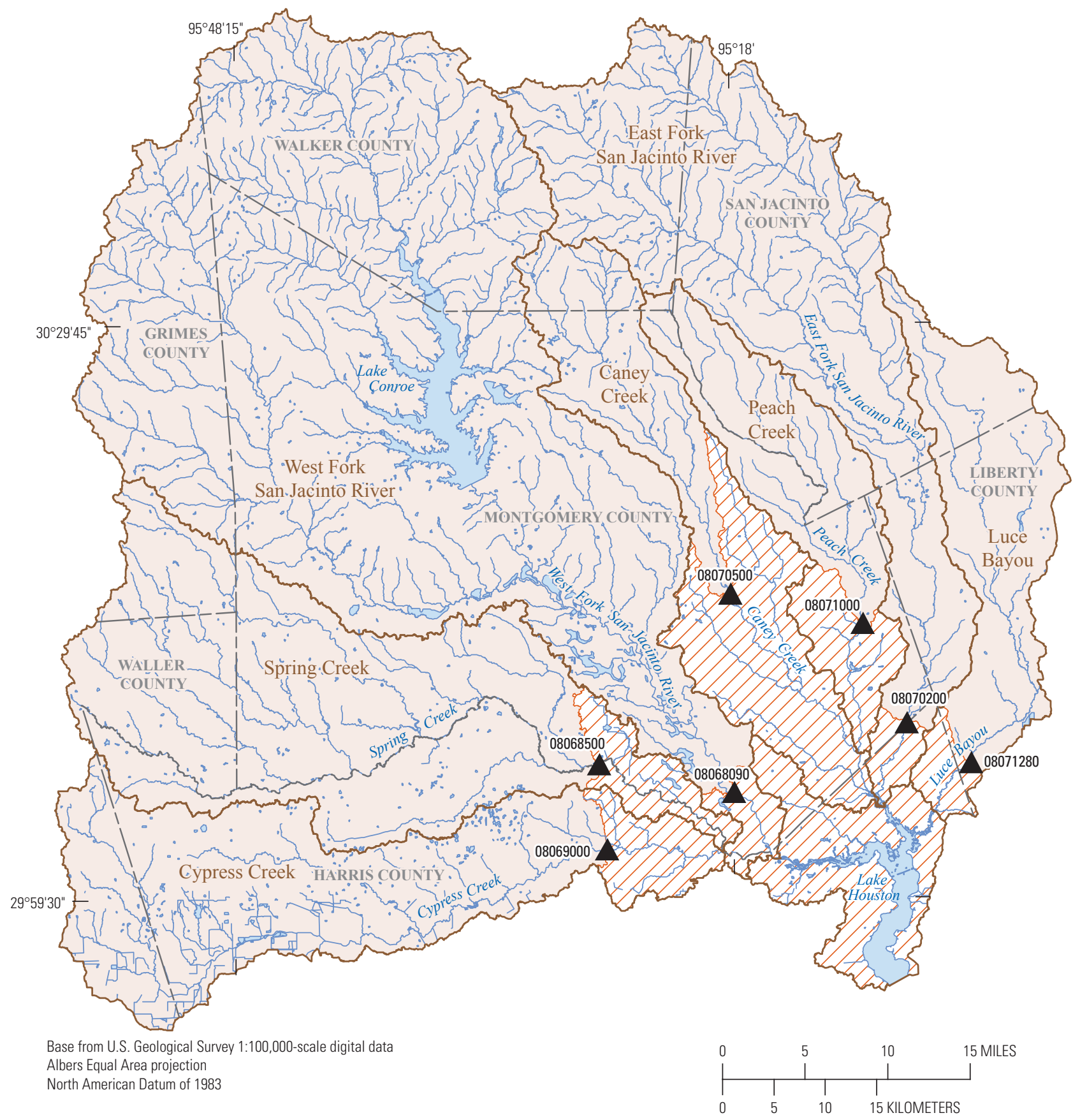

EXPLANATION

Watershed

Gaged area

VIA Ungaged area

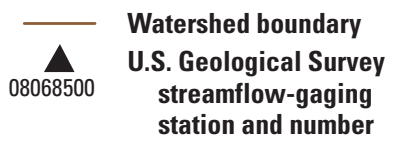

Figure 11. Gaged and ungaged areas of tributary watersheds providing inflows to Lake Houston, near Houston, Texas. 
Table 4. Gaged watershed area, ungaged watershed area, ratio of ungaged to gaged watershed area, and applied scalar factor for estimating the inflows from all tributaries to Lake Houston, near Houston, Texas, during 2009.

[USGS, U.S. Geological Survey; $\mathrm{mi}^{2}$, square mile; --, not applicable]

\begin{tabular}{|c|c|c|c|c|c|c|}
\hline $\begin{array}{l}\text { USGS } \\
\text { station } \\
\text { number }\end{array}$ & USGS station name & Short name & $\begin{array}{c}\text { Gaged } \\
\text { watershed } \\
\text { area } \\
\left(\mathrm{mi}^{2}\right)\end{array}$ & $\begin{array}{c}\text { Ungaged } \\
\text { watershed } \\
\text { area } \\
\left(\mathrm{mi}^{2}\right)\end{array}$ & $\begin{array}{c}\text { Ratio of } \\
\text { ungaged } \\
\text { area to } \\
\text { gaged area }\end{array}$ & $\begin{array}{c}\text { Scalar } \\
\text { factor } \\
\text { (K) }\end{array}$ \\
\hline 08068090 & $\begin{array}{l}\text { West Fork San Jacinto River above } \\
\text { Lake Houston near Porter, Tex. }\end{array}$ & $\begin{array}{l}\text { West Fork San } \\
\text { Jacinto gage }\end{array}$ & 975.5 & 17.21 & 0.02 & 1.05 \\
\hline 08068500 & Spring Creek near Spring, Tex. & Spring Creek gage & 405.7 & 33.51 & 0.08 & 1.12 \\
\hline 08069000 & Cypress Creek near Westfield, Tex. & Cypress Creek gage & 281.0 & 33.49 & 0.12 & 1.16 \\
\hline 08070200 & $\begin{array}{l}\text { East Fork San Jacinto River near New } \\
\text { Caney, Tex. }\end{array}$ & $\begin{array}{l}\text { East Fork San } \\
\text { Jacinto gage }\end{array}$ & 387.8 & 13.13 & 0.03 & 1.07 \\
\hline 08070500 & Caney Creek near Splendora, Tex. & Caney Creek gage & 105.3 & 114.5 & 1.09 & 2.12 \\
\hline 08071000 & Peach Creek at Splendora, Tex. & Peach Creek gage & 118.3 & 38.53 & 0.33 & 1.36 \\
\hline 08071280 & $\begin{array}{l}\text { Luce Bayou above Lake Houston near } \\
\text { Huffman, Tex. }\end{array}$ & Luce Bayou gage & 153.2 & 15.75 & 0.10 & 1.14 \\
\hline-- & Lake Houston & Lake Houston & 2,519 & 92.25 & 0.04 & -- \\
\hline
\end{tabular}

To estimate salinity values for the inflows from the gaged parts of the additional five watersheds, the computed salinity values were compared to instantaneous streamflow at the sites on Spring Creek and the East Fork San Jacinto River, and the following mathematical relation between streamflow and salinity was used:

$$
S=a \times Q^{-b},
$$

where

$$
\begin{aligned}
S & \text { is salinity, in parts per thousand, } \\
a \text { and } b & \text { are curve-fitting coefficients, and } \\
Q & \begin{array}{r}
\text { is the streamflow for each gaged tributary, in } \\
\text { cubic feet per second, at any given time. }
\end{array}
\end{aligned}
$$

The relation between salinity and streamflow developed for the gaged part of the Spring Creek watershed resulted in values of 0.88 and 0.35 for $a$ and $b$, respectively, and a coefficient of determination $\left(\mathrm{R}^{2}\right)$ value (Helsel and Hirsch, 2002) of 0.88; this relation was used to develop a continuous time-series dataset of salinity values for the inflows from the gaged parts of the two other western watersheds (West Fork San Jacinto River and Cypress Creek). For the gaged part of the East Fork San Jacinto River watershed, the values for the $a$ and $b$ coefficients were 0.20 and 0.26 , respectively $\left(\mathrm{R}^{2}=0.40\right)$; this mathematical relation between streamflow and salinity was used to develop the continuous time-series dataset for salinity values for inflows from the gaged parts of the remaining eastern watersheds (Caney Creek, Peach Creek, and Luce Bayou). By using the scalar factor (K) method described in the "Modeled Streamflow" section of this report, salinity values for the ungaged parts of the seven watersheds contributing inflows to Lake Houston (fig. 11) were estimated from the salinity values for the gaged parts of these watersheds. The relations between salinity and streamflow for the East Fork San Jacinto gage in the eastern watersheds and for the Spring Creek gage in the western watersheds are similar, but there is more scatter in the salinity values computed from measured specific conductance for the East Fork San Jacinto gage compared to the Spring Creek gage (fig. 12).

In addition to specific conductance, water temperature data also were collected at the streamflow-gaging stations representing the gaged inflows from the East Fork San Jacinto River and Spring Creek watersheds (table 1). The continually measured water temperature data at these sites were used to represent the temperature values of inflows from the remaining gaged and ungaged parts of the western and eastern watersheds, with the data from the continuously monitored Spring Creek site used to represent water temperature for inflows from the two other western watersheds and the data from the continuously monitored East Fork San Jacinto site used to represent water temperature for inflows from the three other eastern watersheds. The continually measured water temperature data were applied directly to the gaged and ungaged parts of the western and eastern watersheds, with Spring Creek water temperature data applied to the two other western watersheds and East Fork San Jacinto River water temperature data applied to the three other eastern watersheds. 

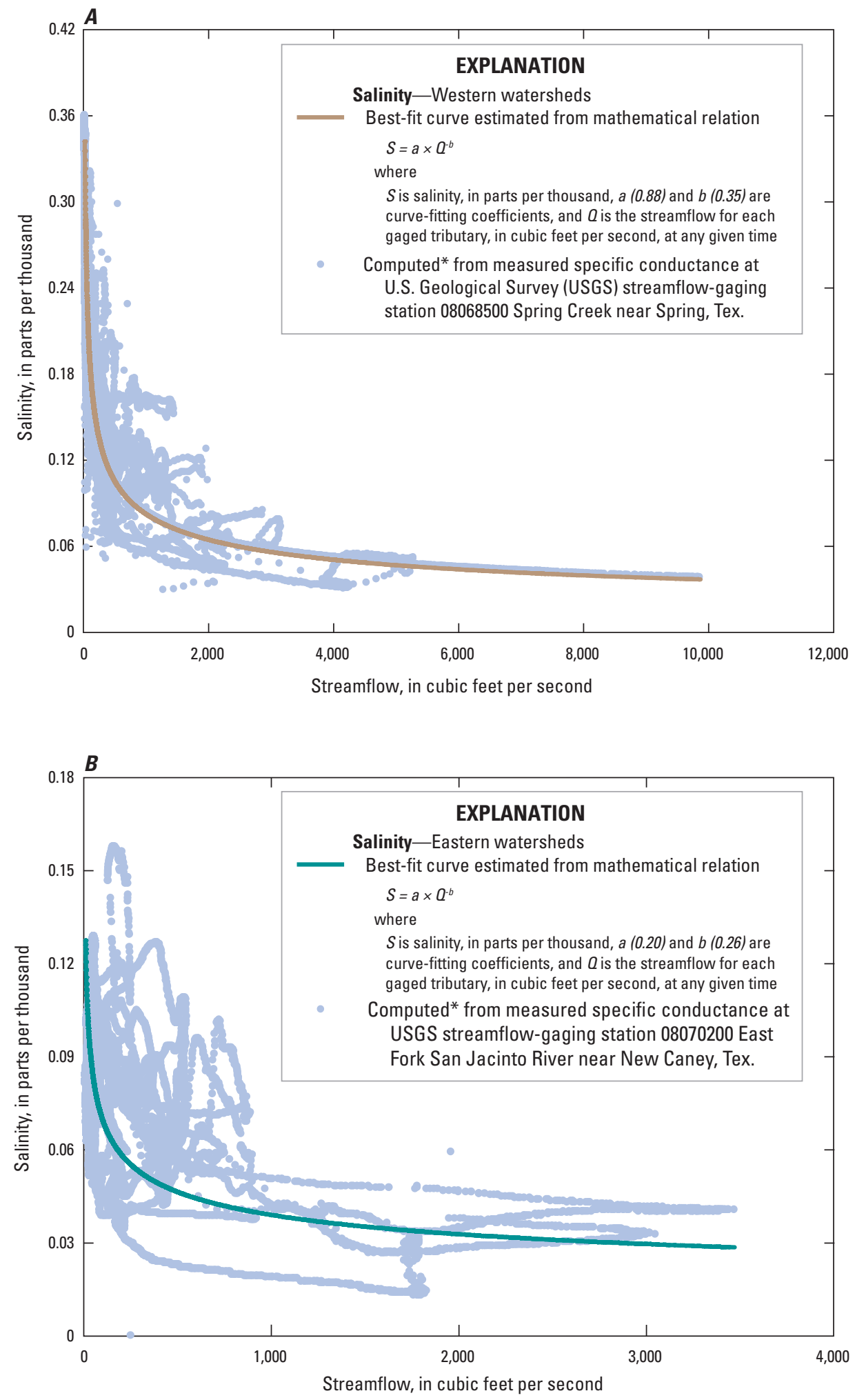

*Salinity was computed by using techniques described in Wagner and others (2006, p. 36).

Figure 12. The relation between salinity, in parts per thousand, and streamflow, in cubic feet per second, during 2009-10 for $A$, U.S. Geological Survey (USGS) streamflow-gaging station 08068500 Spring Creek near Spring, Texas, and $B$, USGS streamflow-gaging station 08070200 East Fork San Jacinto River near New Caney, Tex. 


\section{Simulation of the Effects of Different Inflows on Hydrologic Conditions in Lake Houston}

\section{Meteorological Data}

The meteorological data described in the "Meteorological Data in 2009 and 2010" section of this report were used as inputs for the Lake Houston EFDC model. The aerodynamic method of calculating evaporation from an open body of water (Chow and others, 1988, p. 84-86) is implemented internally in the EFDC model by using selected meteorological data collected for Lake Houston (dry bulb temperature, relative humidity, air pressure, wind speed, and wind direction). Additional information on the calculation of evaporation in the EFDC model is provided by Hamrick $(1992,2007)$.

\section{Model Performance Testing}

The Lake Houston EFDC model was developed and calibrated by using input boundary condition data from 2009. The Lake Houston EFDC model was then verified by using 2010 input boundary condition data as a secondary performance test.

Model results at three locations in the model grid of Lake Houston (at various depths) were compared to measured data collected from the three data collection sites on the lake (fig. 10). The three types of data used to verify model performance were lake elevations, salinity (computed from measured specific conductance), and water temperature. Lake elevations were compared at the Sheldon gage. Salinity and water temperature were compared at the two lake locations, sites $\mathrm{A}$ and $\mathrm{B}$.

Three statistics were used to evaluate performance of the Lake Houston EFDC model: mean error, root mean square error, and the Nash-Sutcliffe model efficiency coefficient (Nash coefficient) (Nash and Sutcliffe, 1970; Wilks, 1995). Mean error is computed as

$$
M E=\frac{1}{n} \sum_{i=1}^{n}\left(S_{i}-M_{i}\right),
$$

where

$$
\begin{array}{cl}
M E & \text { is mean error, } \\
n & \text { is the number of observations, } \\
i & \text { is the given time step, } \\
S & \text { is the simulated value at the given time step, } \\
& \text { and } \\
M & \text { is the measured value at the given time step. }
\end{array}
$$

The mean error is the average difference between the simulated and measured values and can range from negative infinity to infinity. The mean error is used as a goodnessof-fit statistic to help identify possible bias in the simulated values. A positive mean error value indicates that the model is simulating values that are, on average, higher than the measured values; that is, biased high. A negative mean error indicates that the simulation values are biased low (Wilks, 1995).

Root mean square error is a measure of the overall goodness-of-fit of the simulated values to the measured values and is computed as the root of the mean of the squares of the difference between the simulated and measured values as

$$
R M S E=\sqrt{\frac{1}{n} \sum_{i=1}^{n}\left(M_{i}-S_{i}\right)^{2}},
$$

where

$$
\begin{aligned}
R M S E & \text { is root mean square error, } \\
n & \text { is the number of observations, } \\
i & \text { is the given time step, } \\
M & \text { is the measured value at the given time step, } \\
& \text { and } \\
S & \text { is the simulated value at the given time step. }
\end{aligned}
$$

Since the root mean square error has the same units of measure as the quantity being simulated, it represents the error associated with individual simulated values (Hyndman and Koehler, 2006). Root mean square error values can range from 0 to infinity. Stonewall and Bragg (2012) explained that, as root mean square error values approach zero, the model approaches a perfect match between measured and simulated values, with root mean square error values of zero indicating residual values of zero (no difference between the measured and simulated value).

Because mean error and root mean square error retain the units of measure of the original data, normalizing these metrics facilitates comparisons of how well the simulated and measured values for lake elevation, salinity, and water temperature each match; direct comparisons among normalized mean errors and normalized root mean square errors are possible for lake elevation, salinity, and water temperature once they are made proportional. The mean errors for lake elevation, salinity, and water temperature were normalized by dividing them by the range of the measured observations. The normalized mean error equation is

$$
N M E=\frac{M E}{M_{\max }-M_{\min }},
$$

where

$$
\begin{aligned}
N M E & \text { is normalized mean error, } \\
M E & \text { is mean error, } \\
M_{\text {max }} & \text { is the maximum measured value, and } \\
M_{\text {min }} & \text { is the minimum measured value. }
\end{aligned}
$$


In the same way that mean error values were normalized, the root mean square error values for lake elevation, salinity, and water temperature also were normalized by dividing them by the range of the measured observations (maximum value minus the minimum value):

$$
N R M S E=\frac{R M S E}{M_{\max }-M_{\min }},
$$

where

$$
\begin{array}{cl}
\text { NRMSE } & \text { is normalized root mean square error, } \\
R M S E & \text { is root mean square error, } \\
M_{\text {max }} & \text { is the maximum measured value, and } \\
M_{\text {min }} & \text { is the minimum measured value. }
\end{array}
$$

The following equation is used to compute the Nash coefficient:

Nash coefficient $=1-\left[\sum_{i=1}^{n}\left(M_{i}-S_{i}\right)^{2} / \sum_{i=1}^{n}\left(M_{i}-M_{\text {mean }}\right)^{2}\right]$,

where

$\begin{array}{cl}n & \text { is the number of observations, } \\ i & \text { is the given time step, } \\ M_{i} & \text { is the measured value at the given time step, } \\ S_{i} & \text { is the simulated value at the given time step, } \\ & \text { and } \\ M_{\text {mean }} & \text { is the mean of the measured values. }\end{array}$

Just as the normalized mean error and normalized root mean square error are dimensionless, the Nash coefficient also is dimensionless, which makes comparisons of how well the simulated and measured values match for lake elevation, salinity, and water temperature straightforward. The Nash coefficient can range from negative infinity to 1 . A Nash coefficient of 1 would indicate that the simulated data are a perfect match to the measured data, a Nash coefficient of 0 would indicate that the simulated data are as good of a predictor as the mean of the measured data, and a Nash coefficient of less than 0 indicates that the mean of the measured data is a better predictor than the mean of the simulated data (Nash and Sutcliffe, 1970). Moriasi (2007) considered Nash coefficients of 0.50 or larger indicative of a satisfactory match between the simulated and measured data.

\section{Lake Elevation}

A comparison of simulated to measured lake elevations provides insights into the Lake Houston EFDC model performance in terms of the overall mass balance of water in Lake Houston. There was a generally good fit between the simulated and measured lake elevations during 2009 and 2010, with little overall bias (figs. 13 and 14). The largest deviation of the simulated lake elevations of approximately

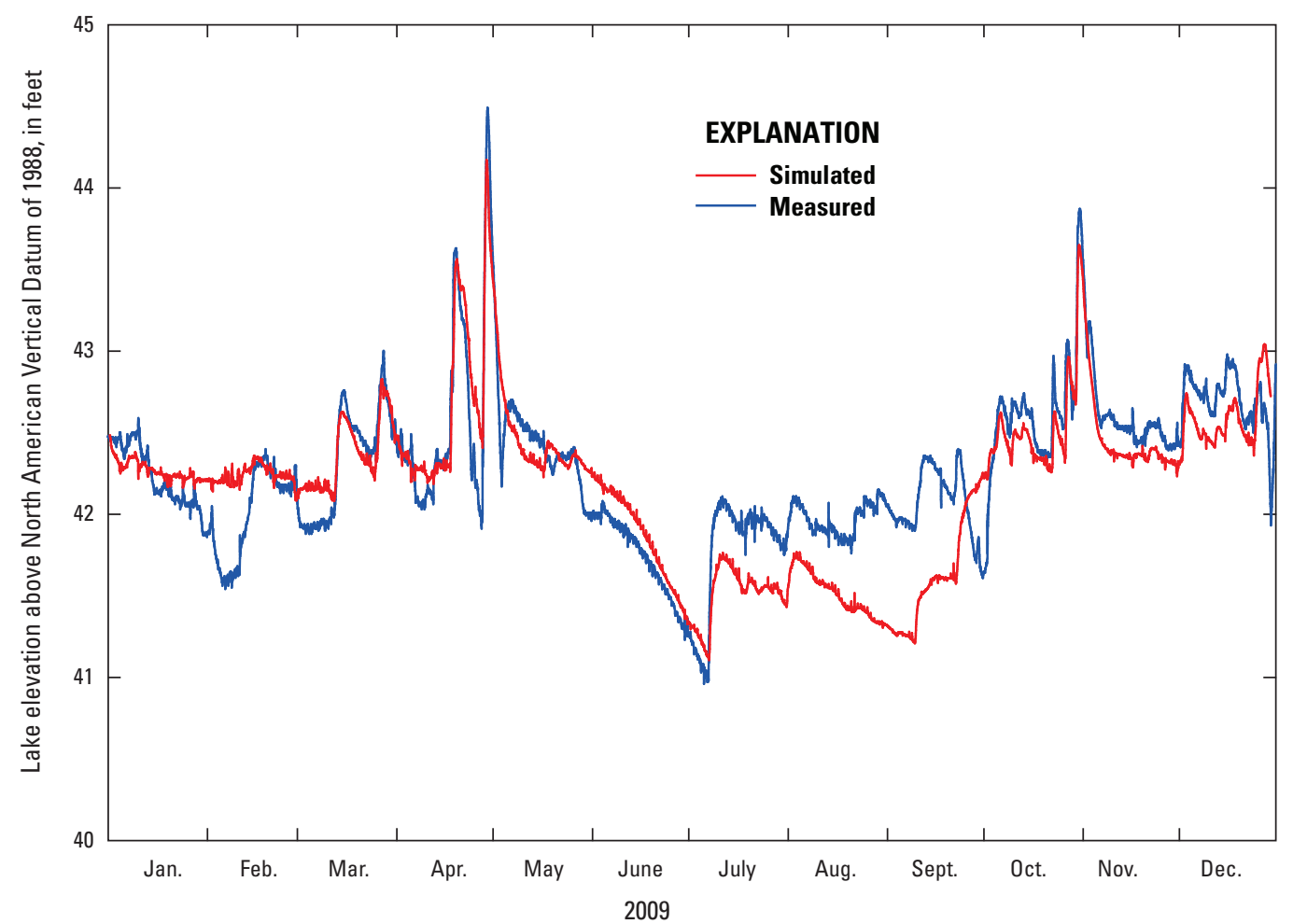

Figure 13. Simulated and measured lake elevations at U.S. Geological Survey reservoir station 08072000 Lake Houston near Sheldon, Texas, 2009. 


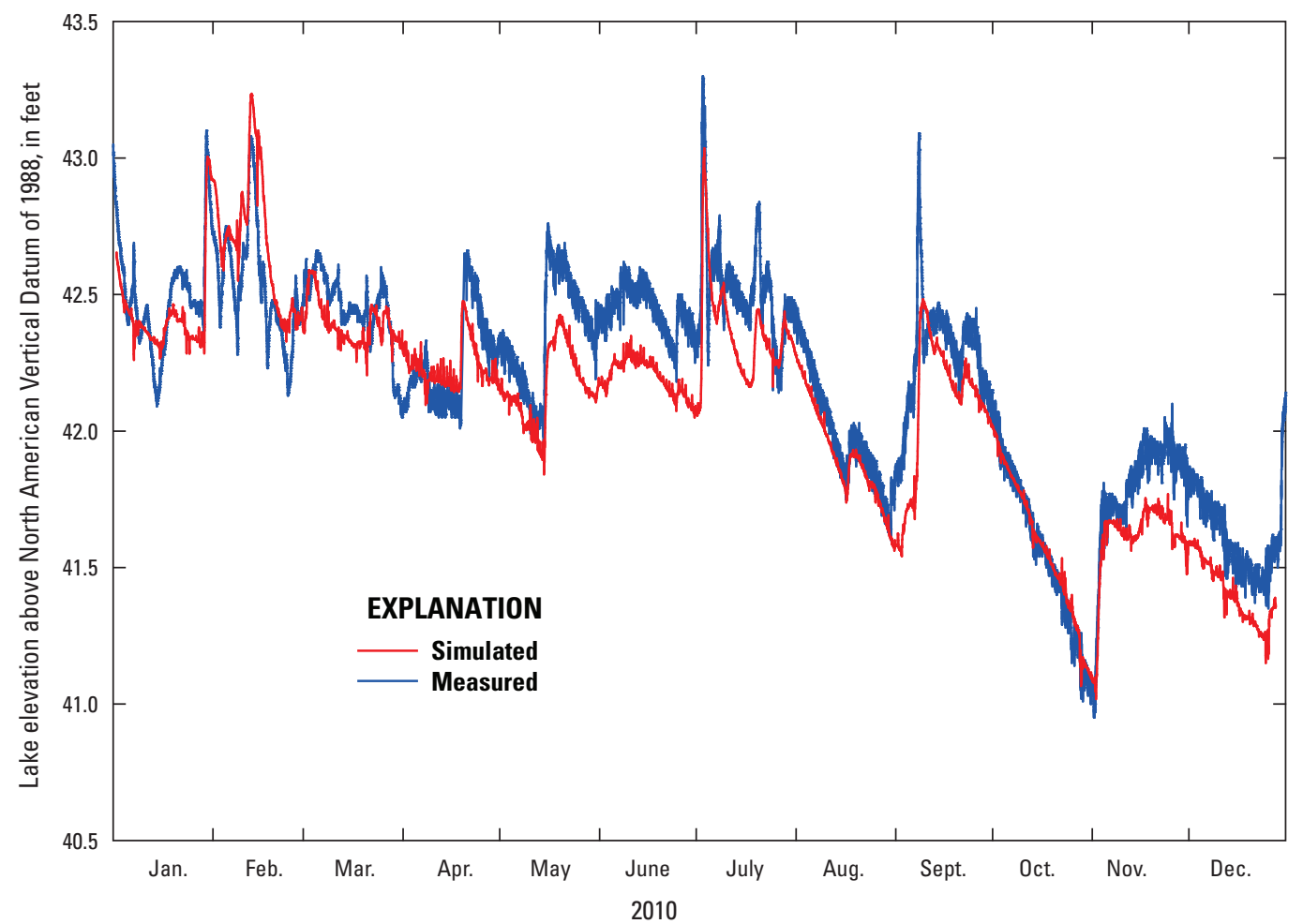

Figure 14. Simulated and measured lake elevations at U.S. Geological Survey reservoir station 08072000 Lake Houston near Sheldon, Texas, 2010.

$1 \mathrm{ft}$ from measured values was observed during the summer months, with the simulated and measured values converging once again during the remainder of the year. For model runs using 2010 input boundary conditions, the simulated and measured lake-elevation values are similar. During 2009-10, mean error for lake elevation ranged from -0.102 to $-0.080 \mathrm{ft}$, whereas the normalized (dimensionless) mean error for lake elevation ranged from -0.04 to -0.02 , indicating a small negative bias in the model simulated values. Root mean square error values were within a small range from 0.20 to $0.31 \mathrm{ft}$; the normalized root mean square errors for lake elevation equaled 0.09 . The dimensionless Nash coefficient ranged from 0.54 to 0.75 (table 5). Although the Nash coefficient values did not closely approximate 1 , they were consistently larger than 0.50 , the lower limit of what Moriasi and others (2007) defined as indicative of satisfactory model performance. The normalized mean error and normalized root mean square error closely approximated zero. On an overall basis the performance evaluation statistics corroborate that the model performed satisfactorily in terms of simulating lake elevations.

Table 5. Performance evaluation statistics for simulated lake elevation relative to measured lake elevation in Lake Houston, near Houston, Texas, 2009 and 2010.

[Mean errors, root mean square errors, and Nash-Sutcliffe model efficiency coefficients were determined by using the Environmental Fluid Dynamics Computer Code (EFDC) surface-water modeling package (Hamrick, 1992, 2007). ft, foot]

\begin{tabular}{cccccc}
\hline Year & $\begin{array}{c}\text { Mean error } \\
(\mathbf{f t})\end{array}$ & $\begin{array}{c}\text { Normalized } \\
\text { mean error } \\
\text { (dimensionless) }\end{array}$ & $\begin{array}{c}\text { Root mean } \\
\text { square error } \\
(\mathbf{f t})\end{array}$ & $\begin{array}{c}\text { Normalized root } \\
\text { mean square error } \\
\text { (dimensionless) }\end{array}$ & $\begin{array}{c}\text { Nash-Sutcliffe model } \\
\text { efficiency coefficient } \\
\text { (dimensionless) }\end{array}$ \\
\hline 2009 & -0.080 & -0.02 & 0.31 & 0.09 & 0.54 \\
2010 & -0.102 & -0.04 & 0.20 & 0.09 & 0.75 \\
\hline
\end{tabular}




\section{Salinity Computed From Specific Conductance and Water Temperature}

Comparisons between simulated salinity and salinity computed from measured specific conductance can provide insights into a model's performance in terms of overall hydrodynamics. Comparisons were made between simulated salinity values and salinity values computed from measured specific conductance for two locations in Lake Houston, site A and site B (figs. 15 and 16). During 2009 and 2010, specific conductance and water temperature were measured at four incremental depths, $1,6,12$, and $16 \mathrm{ft}$, at site B. At site A, specific conductance and water temperature were measured at $1,6,12$, and $16 \mathrm{ft}$ in 2009 but only measured at the $1-\mathrm{ft}$ depth in 2010. Mean error ranged from -0.009 to -0.0039 part per thousand for salinity (normalized mean error ranged from 0.10 to -0.09). Root mean square error ranged from 0.011 to 0.013 part per thousand for salinity (normalized root mean square error ranged from 0.12 to 0.14 ). The normalized mean error and normalized root mean square error closely approximated zero, and the Nash coefficient ranged from 0.66 to 0.86 , indicating that the model performed satisfactorily in terms of simulating salinity (Moriasi and others, 2007). The model performance evaluation statistics for salinity in 2009 and 2010 are summarized in table 6 .

During the summer months, simulated water temperatures generally are biased slightly high compared to measured water temperatures (figs. 17 and 18); however, this bias is not sufficient to hinder the Lake Houston EFDC model's ability to accurately represent energy balance and mixing potential during the simulated time periods. On an overall basis, the performance evaluation statistics indicate that the model performed satisfactorily in terms of matching simulated to measured temperatures with relatively little bias and small residual values. During 2009-10, the mean error for temperature ranged from -0.20 to $2.84^{\circ} \mathrm{F}$ (normalized mean error ranged from 0 to 0.06 ), and the root mean square error ranged from 1.49 to $3.83{ }^{\circ} \mathrm{F}$ (normalized root mean square error ranged from 0.04 to 0.08 ). The normalized mean error and normalized root mean square error closely approximated zero, and the Nash coefficient ranged from 0.92 to 0.98 , indicating the model performed satisfactorily in terms of simulating water temperature. All of the performance evaluation statistics for water temperature in 2009 and 2010 are listed in table 7.

\section{Model Limitations}

Hydrodynamic models are simplified representations of complex systems that allow the hydrodynamics of a lake or other body of water to be simulated and visualized in a manner that otherwise might not be possible. The actual natural processes cannot be described completely through mathematical formulas, so models must inherently be conceptual (Liscum and East, 2000).

The Lake Houston EFDC model was built to characterize the hydrodynamics of Lake Houston. Because models must be calibrated and tested by using input data collected in the field, uncertainty may be introduced by inaccuracies or limitations of the input datasets.

Bathymetric data collected more than 20 years ago were used to calculate the storage capacity of Lake Houston in the EFDC model. Inaccuracies in the bathymetric data can arise from changes in the geometry of Lake Houston caused by the addition or removal of bed sediments since the last survey was completed in 1994, the relatively coarse resolution at which the bathymetric data were collected, and the need to average bathymetric data over large grid areas for the model. To minimize uncertainty in the geometric data, up-to-date bathymetric data would need to be collected; however, the collection of new bathymetric data at the same resolution at which the existing data were collected would not mitigate errors associated with the averaging of the data over large grid cells.

Inaccuracies associated with inflows to Lake Houston from ungaged areas are another source of uncertainty. For this model, inflows to Lake Houston from ungaged areas of the watersheds were extrapolated from streamflow measured for gaged areas as explained in the "Modeled Streamflow" section of this report. Although relating drainage area to streamflow is a common practice in this type of modeling application, it may not accurately represent the inflows to Lake Houston from ungaged areas because of differences in land use. To fully characterize all of the inflows to Lake Houston, streamflowgaging stations would need to be installed on each of the tributaries near their confluences with the lake, and streamflow data would need to be collected for a sufficient period of time for modeling purposes (likely several years). 

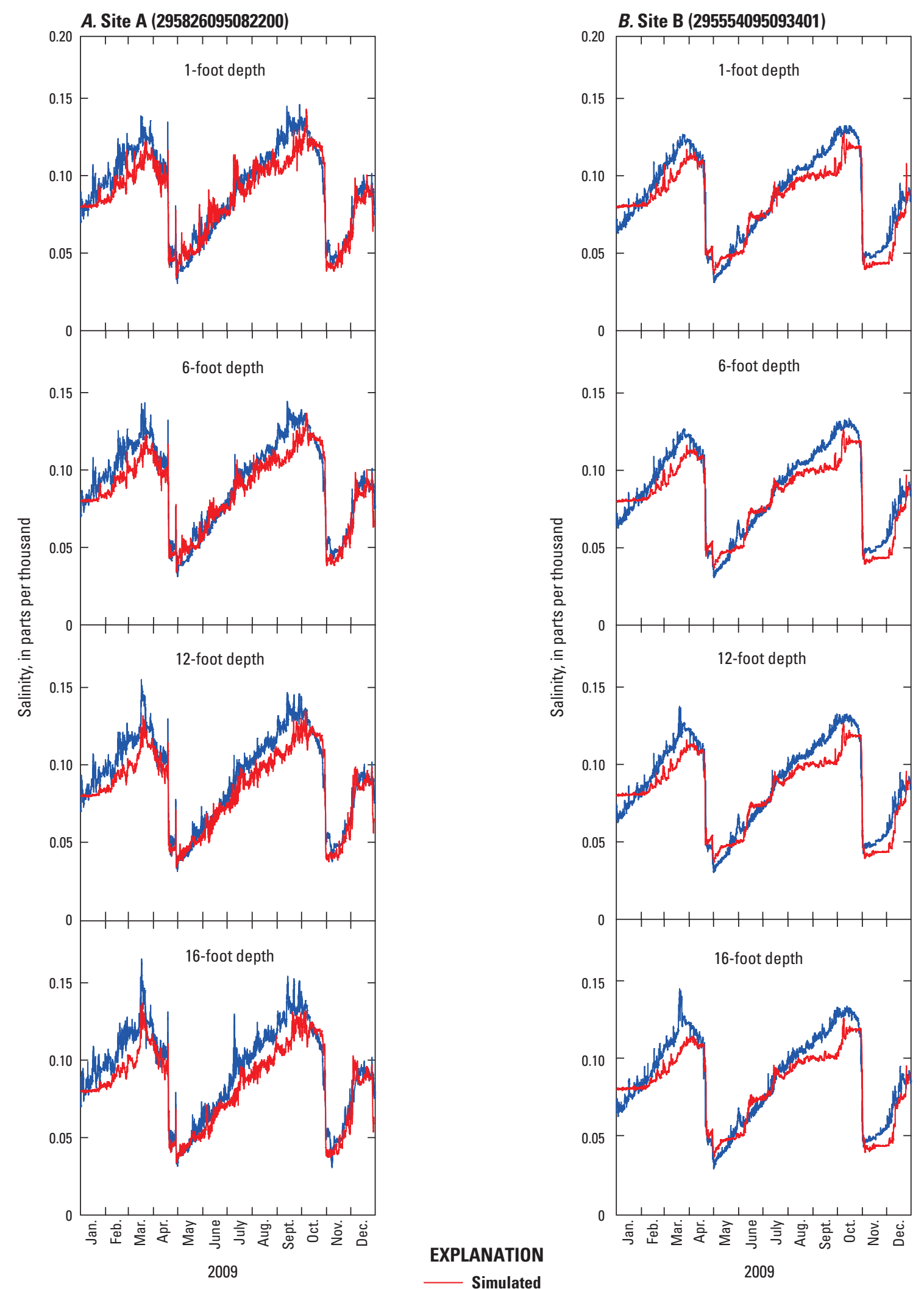

Figure 15. Simulated salinity and salinity computed from measured specific conductance measured in 2009 at U.S. Geological Survey reservoir stations on Lake Houston, near Houston, Texas. A, 295826095082200 Lake Houston south Union Pacific Railroad Bridge near Houston, Tex. B, 295554095093401 Lake Houston at mouth of Jack's Ditch near Houston, Tex. 

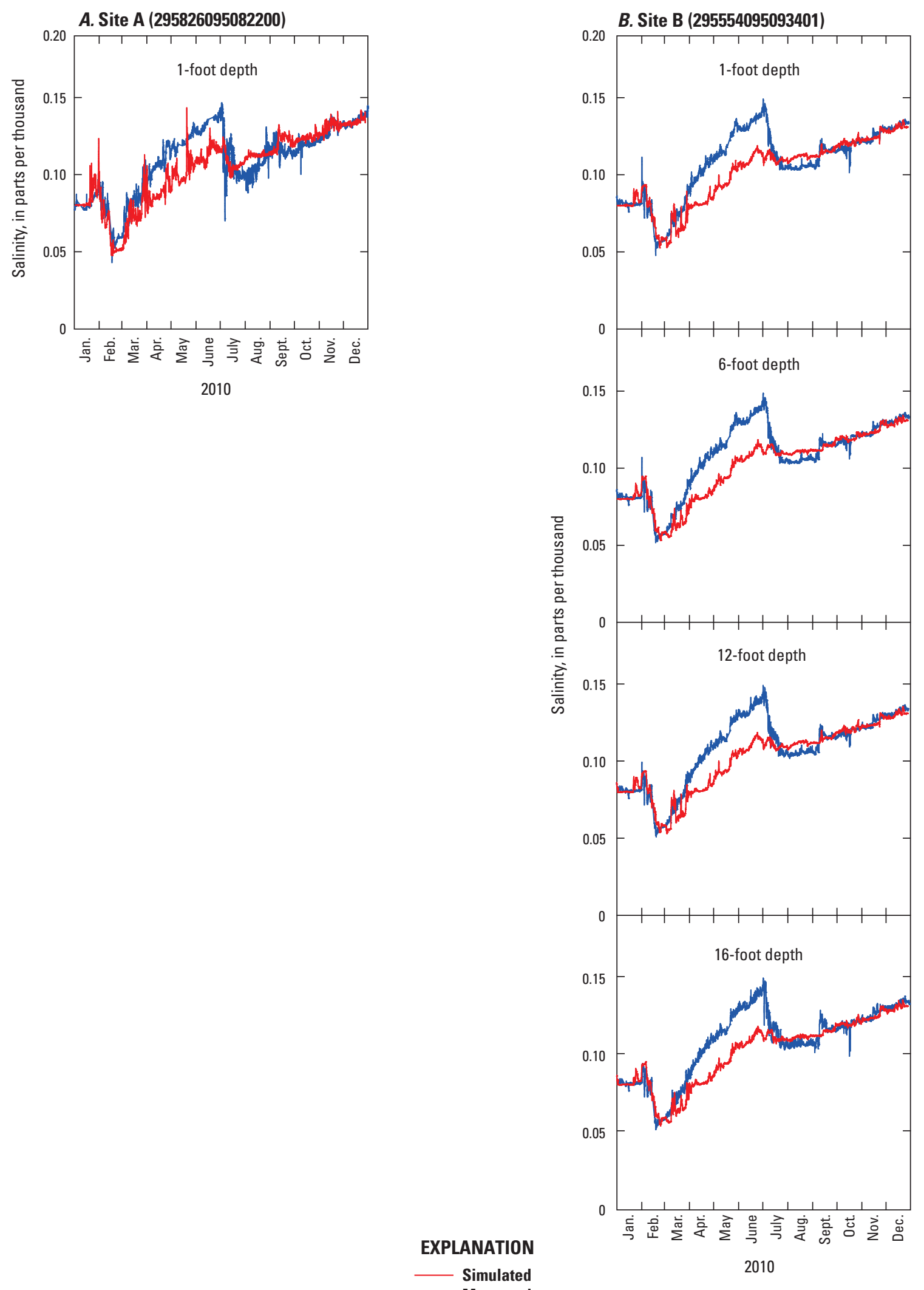

Figure 16. Simulated salinity and salinity computed from measured specific conductance measured in 2010 at U.S. Geological Survey reservoir stations on Lake Houston, near Houston, Texas. A, 295826095082200 Lake Houston south Union Pacific Railroad Bridge near Houston, Tex. B, 295554095093401 Lake Houston at mouth of Jack's Ditch near Houston, Tex. 
Table 6. Performance evaluation statistics for simulated salinity and salinity computed from measured specific conductance at U.S. Geological Survey reservoir stations 295826095082200 Lake Houston south Union Pacific Railroad Bridge near Houston, Texas, and 295554095093401 Lake Houston at mouth of Jack's Ditch near Houston, Tex., 2009 and 2010.

[USGS, U.S. Geological Survey; ft, foot; ppt, part per thousand]

\begin{tabular}{|c|c|c|c|c|c|c|c|c|}
\hline $\begin{array}{l}\text { USGS station } \\
\text { number }\end{array}$ & USGS station name & $\begin{array}{l}\text { Short } \\
\text { name }\end{array}$ & $\begin{array}{l}\text { Depth } \\
\text { (ft) }\end{array}$ & $\begin{array}{l}\text { Mean } \\
\text { error } \\
\text { (ppt) }\end{array}$ & $\begin{array}{c}\text { Normalized } \\
\text { mean error } \\
\text { (dimensionless) }\end{array}$ & $\begin{array}{l}\text { Root mean } \\
\text { square error } \\
\text { (ppt) }\end{array}$ & $\begin{array}{l}\text { Normalized } \\
\text { root mean } \\
\text { square error } \\
\text { (dimensionless) }\end{array}$ & $\begin{array}{l}\text { Nash-Sutcliffe } \\
\text { model efficiency } \\
\text { coefficient } \\
\text { (dimensionless) }\end{array}$ \\
\hline \multicolumn{9}{|c|}{2009} \\
\hline 295826095082200 & $\begin{array}{l}\text { Lake Houston south Union Pacific Railroad Bridge } \\
\text { near Houston, Tex. }\end{array}$ & Site A & 1 & -0.0053 & -0.06 & 0.011 & 0.12 & 0.84 \\
\hline 295826095082200 & $\begin{array}{l}\text { Lake Houston south Union Pacific Railroad Bridge } \\
\text { near Houston, Tex. }\end{array}$ & Site A & 6 & -0.0061 & -0.07 & 0.011 & 0.12 & 0.85 \\
\hline 295826095082200 & $\begin{array}{l}\text { Lake Houston south Union Pacific Railroad Bridge } \\
\text { near Houston, Tex. }\end{array}$ & Site A & 12 & -0.0079 & -0.09 & 0.012 & 0.13 & 0.82 \\
\hline 295826095082200 & $\begin{array}{l}\text { Lake Houston south Union Pacific Railroad Bridge } \\
\text { near Houston, Tex. }\end{array}$ & Site A & 16 & -0.0090 & 0.10 & 0.013 & 0.14 & 0.80 \\
\hline 295554095093401 & $\begin{array}{l}\text { Lake Houston at mouth of Jack's Ditch near } \\
\text { Houston, Tex. }\end{array}$ & Site B & 1 & -0.0054 & -0.06 & 0.011 & 0.12 & 0.85 \\
\hline 295554095093401 & $\begin{array}{l}\text { Lake Houston at mouth of Jack's Ditch near } \\
\text { Houston, Tex. }\end{array}$ & Site B & 6 & -0.0055 & -0.06 & 0.011 & 0.12 & 0.86 \\
\hline 295554095093401 & $\begin{array}{l}\text { Lake Houston at mouth of Jack's Ditch near } \\
\text { Houston, Tex. }\end{array}$ & Site B & 12 & -0.0056 & -0.06 & 0.011 & 0.12 & 0.85 \\
\hline 295554095093401 & $\begin{array}{l}\text { Lake Houston at mouth of Jack's Ditch near } \\
\text { Houston, Tex. }\end{array}$ & Site B & 16 & -0.0060 & -0.07 & 0.012 & 0.13 & 0.83 \\
\hline \multicolumn{9}{|c|}{2010} \\
\hline 295826095082200 & $\begin{array}{l}\text { Lake Houston south Union Pacific Railroad Bridge } \\
\text { near Houston, Tex. }\end{array}$ & Site A & 1 & -0.0039 & -0.04 & 0.012 & 0.12 & 0.66 \\
\hline 295554095093401 & $\begin{array}{l}\text { Lake Houston at mouth of Jack's Ditch near } \\
\text { Houston, Tex. }\end{array}$ & Site B & 1 & -0.0056 & -0.06 & 0.013 & 0.13 & 0.66 \\
\hline 295554095093401 & $\begin{array}{l}\text { Lake Houston at mouth of Jack's Ditch near } \\
\text { Houston, Tex. }\end{array}$ & Site B & 6 & -0.0058 & -0.06 & 0.013 & 0.13 & 0.66 \\
\hline 295554095093401 & $\begin{array}{l}\text { Lake Houston at mouth of Jack's Ditch near } \\
\text { Houston, Tex. }\end{array}$ & Site B & 12 & -0.0060 & -0.06 & 0.012 & 0.12 & 0.69 \\
\hline 295554095093401 & $\begin{array}{l}\text { Lake Houston at mouth of Jack's Ditch near } \\
\text { Houston, Tex. }\end{array}$ & Site B & 16 & -0.0063 & -0.06 & 0.013 & 0.13 & 0.69 \\
\hline
\end{tabular}



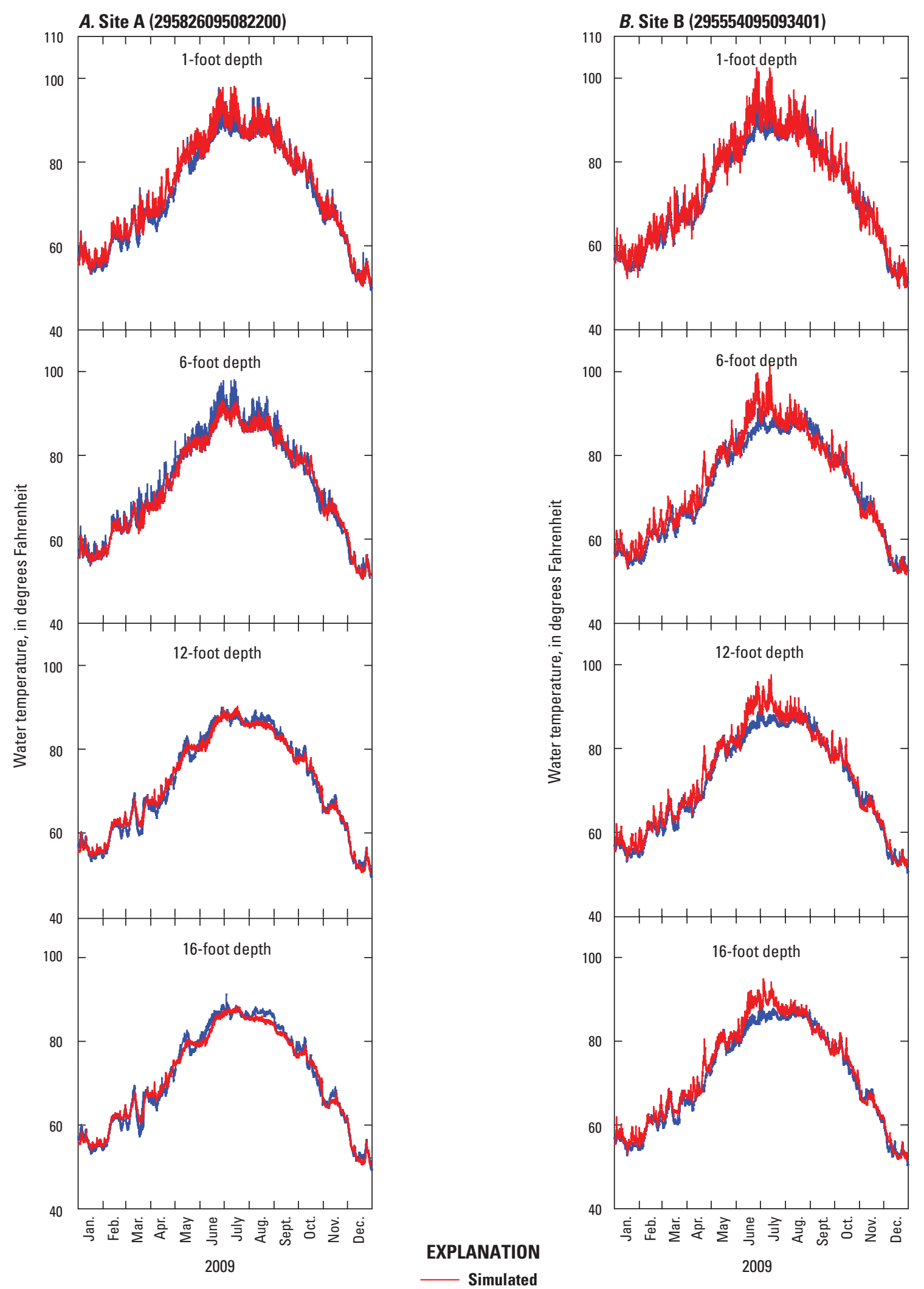

Figure 17. Simulated and measured water temperature at U.S. Geological Survey reservoir stations on Lake Houston, near Houston, Texas, in 2009. A, 295826095082200 Lake Houston south Union Pacific Railroad Bridge near Houston, Tex. B, 295554095093401 Lake Houston at mouth of Jack's Ditch near Houston, Tex. 

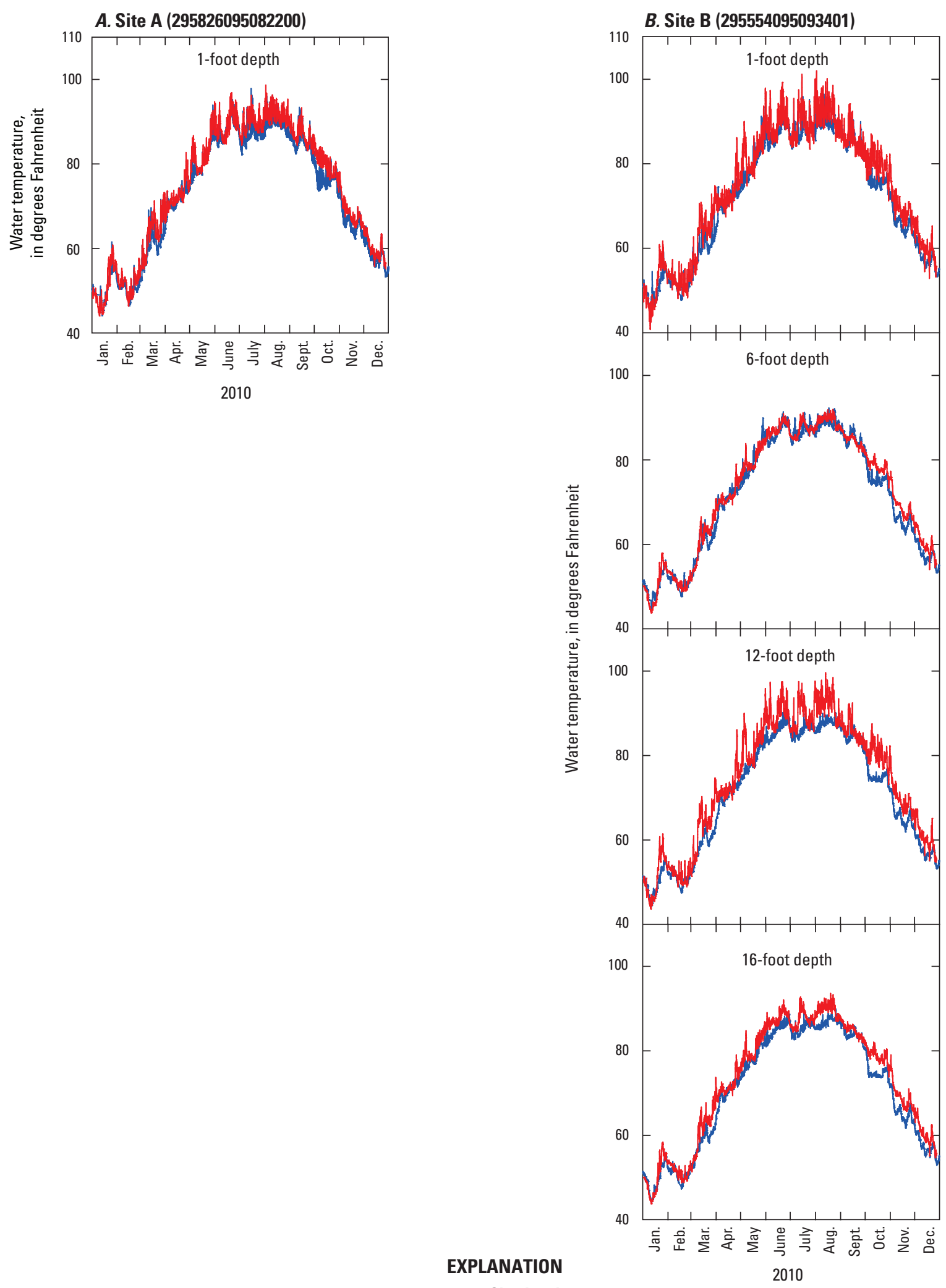

Figure 18. Simulated and measured water temperature at U.S. Geological Survey reservoir stations on Lake Houston, near Houston, Texas, in 2010. A, 295826095082200 Lake Houston south Union Pacific Railroad Bridge near Houston, Tex. B, 295554095093401 Lake Houston at mouth of Jack's Ditch near Houston, Tex. 
Table 7. Performance evaluation statistics for simulated and measured water temperature at U.S. Geological Survey reservoir stations 295826095082200 Lake Houston south Union Pacific Railroad Bridge near Houston, Texas, and 295554095093401 Lake Houston at mouth of Jack's Ditch near Houston, Tex., 2009 and 2010.

[USGS, U.S. Geological Survey; ft, foot; ${ }^{\circ}$ F, degree Fahrenheit]

\begin{tabular}{|c|c|c|c|c|c|c|c|c|}
\hline $\begin{array}{l}\text { USGS station } \\
\text { number }\end{array}$ & USGS station name & $\begin{array}{l}\text { Short } \\
\text { name }\end{array}$ & $\begin{array}{c}\text { Depth } \\
\text { (ft) }\end{array}$ & $\begin{array}{c}\text { Mean } \\
\text { error } \\
\left({ }^{\circ} \mathrm{F}\right)\end{array}$ & $\begin{array}{c}\text { Normalized } \\
\text { mean error } \\
\text { (dimensionless) }\end{array}$ & $\begin{array}{c}\text { Root mean } \\
\text { square error } \\
\left({ }^{\circ} \mathrm{F}\right)\end{array}$ & $\begin{array}{c}\text { Normalized } \\
\text { root mean square } \\
\text { error } \\
\text { (dimensionless) }\end{array}$ & $\begin{array}{c}\text { Nash-Sutcliffe } \\
\text { model efficiency } \\
\text { coefficient } \\
\text { (dimensionless) }\end{array}$ \\
\hline \multicolumn{9}{|c|}{2009} \\
\hline 295826095082200 & $\begin{array}{l}\text { Lake Houston south Union Pacific Railroad Bridge } \\
\text { near Houston, Tex. }\end{array}$ & Site A & 1 & 1.10 & 0.02 & 2.39 & 0.05 & 0.96 \\
\hline 295826095082200 & $\begin{array}{l}\text { Lake Houston south Union Pacific Railroad Bridge } \\
\text { near Houston, Tex. }\end{array}$ & Site A & 6 & 0.81 & 0.02 & 1.80 & 0.04 & 0.98 \\
\hline 295826095082200 & $\begin{array}{l}\text { Lake Houston south Union Pacific Railroad Bridge } \\
\text { near Houston, Tex. }\end{array}$ & Site A & 12 & 0.05 & 0.00 & 1.49 & 0.04 & 0.98 \\
\hline 295826095082200 & $\begin{array}{l}\text { Lake Houston south Union Pacific Railroad Bridge } \\
\text { near Houston, Tex. }\end{array}$ & Site A & 16 & -0.20 & 0.00 & 1.55 & 0.04 & 0.98 \\
\hline 295554095093401 & $\begin{array}{l}\text { Lake Houston at mouth of Jack's Ditch near } \\
\text { Houston, Tex. }\end{array}$ & Site B & 1 & 1.20 & 0.03 & 3.13 & 0.07 & 0.93 \\
\hline 295554095093401 & $\begin{array}{l}\text { Lake Houston at mouth of Jack's Ditch near } \\
\text { Houston, Tex. }\end{array}$ & Site B & 6 & 1.26 & 0.03 & 2.72 & 0.07 & 0.95 \\
\hline 295554095093401 & $\begin{array}{l}\text { Lake Houston at mouth of Jack's Ditch near } \\
\text { Houston, Tex. }\end{array}$ & Site B & 12 & 1.28 & 0.03 & 2.39 & 0.06 & 0.96 \\
\hline 295554095093401 & $\begin{array}{l}\text { Lake Houston at mouth of Jack's Ditch near } \\
\text { Houston, Tex. }\end{array}$ & Site B & 16 & 1.21 & 0.03 & 2.16 & 0.05 & 0.97 \\
\hline \multicolumn{9}{|c|}{2010} \\
\hline 295826095082200 & $\begin{array}{l}\text { Lake Houston south Union Pacific Railroad Bridge } \\
\text { near Houston, Tex. }\end{array}$ & Site A & 1 & 1.93 & 0.04 & 3.01 & 0.06 & 0.95 \\
\hline 295554095093401 & $\begin{array}{l}\text { Lake Houston at mouth of Jack's Ditch near } \\
\text { Houston, Tex. }\end{array}$ & Site B & 1 & 2.20 & 0.04 & 3.83 & 0.07 & 0.92 \\
\hline 295554095093401 & $\begin{array}{l}\text { Lake Houston at mouth of Jack's Ditch near } \\
\text { Houston, Tex. }\end{array}$ & Site B & 6 & 1.93 & 0.04 & 3.46 & 0.07 & 0.94 \\
\hline 295554095093401 & $\begin{array}{l}\text { Lake Houston at mouth of Jack's Ditch near } \\
\text { Houston, Tex. }\end{array}$ & Site B & 12 & 2.84 & 0.06 & 3.64 & 0.08 & 0.92 \\
\hline 295554095093401 & $\begin{array}{l}\text { Lake Houston at mouth of Jack's Ditch near } \\
\text { Houston, Tex. }\end{array}$ & Site B & 16 & 2.29 & 0.05 & 2.93 & 0.06 & 0.95 \\
\hline
\end{tabular}


Specific conductance and water temperature were only collected at two streamflow-gaging stations representing the gaged areas of two of the seven major tributaries to Lake Houston, so the extrapolation of these data to represent the gaged and ungaged areas of all seven watersheds is a potential source of error. Salinity rather than specific conductance is needed as input in the EFDC model, so any errors introduced when salinity is computed from measured specific conductance are another source of model uncertainty. There is also uncertainty associated with the relations between salinity and streamflow derived for the two inflow tributaries where specific conductance and water temperature are collected and with the salinity to streamflow relations from the gaged areas of the two watersheds that were extrapolated to the remaining tributaries in the watershed. The methodology used to estimate salinity may not yield salinity values that fully characterize each of the individual tributaries. Furthermore, because the relation between salinity and streamflow for the East Fork San Jacinto gage in the eastern watersheds is not as good compared to the relation between salinity and streamflow for the Spring Creek gage in the western watersheds (evidenced by the larger amount of scatter in the salinity values computed from measured specific conductance at the East Fork San Jacinto gage compared to those computed at the Spring Creek gage), there was relatively more uncertainty associated with the estimated salinity values computed for the eastern watersheds compared to the amount of uncertainty associated with estimated salinity values in the western watersheds.

There also is uncertainty associated with the extrapolation of water temperature measured from one tributary in each of the western and eastern watersheds to the remaining tributaries in the western and eastern watersheds. To more accurately characterize the salinity and water temperature for each of the tributaries, data would have to be collected at each of the individual tributaries.

The hydraulic structure boundary condition cells used in the Lake Houston EFDC model require a rating curve relating the hydraulic head of the outflow over the dam to flow rate. Although a rating curve for flow over the San Jacinto Dam was available, the length of the dam and the fact that it is not perfectly level make it difficult to quantify flow rates at the low end of the rating curve. To improve the accuracy of this rating curve, additional measurements are needed at low flow rates.

\section{Simulation of the Effects of Different Inflows on Hydrologic Conditions in Lake Houston}

After the Lake Houston EFDC model was developed as explained in the "Development of a Three-Dimensional
Hydrodynamic Model" section of this report, the model was verified by using 2010 input boundary condition data as a performance test. Inspection of the spatial distributions of the residence time of water, salinity, and water temperature obtained from outputs of model simulations using the 2009 and 2010 data yields insight into the overall hydrodynamics of Lake Houston. Spatially distributed plan and profile views, as well as five representative cross sections, were chosen to illustrate the changes in residence time and salinity over time and location in the lake (fig. 19).

The inflow events on April 19-20, April 28-29, and October 30-31, 2009 (fig. 3), in relation to the residence time and salinity were assessed to gain an understanding of the hydrodynamics of the lake. On the basis of it shape, Lake Houston can be conceptually separated into two parts, a northern part upstream from the Farm to Market (FM) 1960 Bridge over Lake Houston and a southern part downstream from the FM 1960 Bridge (fig. 19). The inflows to Lake Houston from the western and eastern watersheds are less well mixed in the northern part of the lake, with the degree of mixing of the inflows from the western and eastern watersheds increasing in the downstream direction from the FM 1960 Bridge (figs. 20 and 21). Plan view and profile view plots of the residence time and salinity can lead to a better understanding of vertical and horizontal gradients in Lake Houston during inflow events. An example of plan and profile views is provided of a modeled change in residence time at representative cross sections in Lake Houston that resulted from an inflow event during April 19-20, 2009 (fig. 20). This pattern of the water flowing into the lake from each of the two contributing watersheds staying closer to their respective side of the lake and not fully mixing until reaching the southern part of the lake is evident in all of the events that were studied (figs. 20 and 21).

Larger inflow events can appreciably change the overall residence time of water in the lake, whereas smaller inflow events do not have much effect on residence time (fig. 22). The smaller events preceding the April 19-20, 2009, inflow event have greater influence on the upper part of the lake than on the lower part of the lake. The April 19-20, 2009, inflow event did affect the entire lake, accelerating the movement of water through the lake and reducing the residence time at all of the five representative cross sections. The April 28-29, 2009, inflow event then continued to accelerate the movement of water through the lake. By considering differences in residence time among the five cross sections (fig. 22), patterns in the traveltime of the water in Lake Houston become evident. For example, it is evident that the traveltime of water through the lake is not constant. Smaller events have larger traveltimes compared to larger events, and effects on residence times may not be propagated all of the way to the downstream end of the lake, whereas larger events accelerate the movement of water through the lake and, when sufficiently large, can completely flush the lake. 


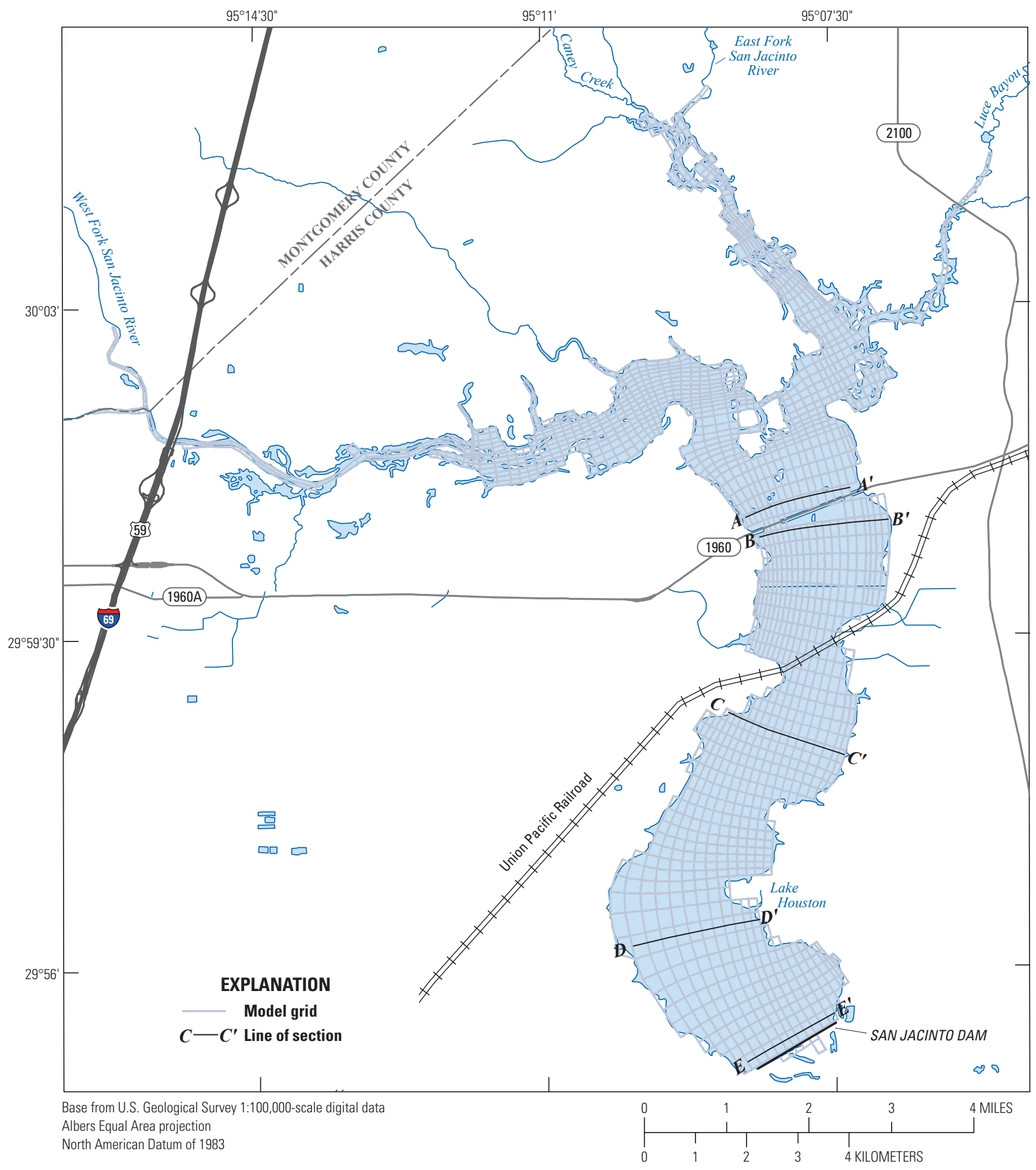

Figure 19. Locations of representative cross sections used to illustrate simulations from the three-dimensional hydrodynamic model of Lake Houston, near Houston, Texas. 


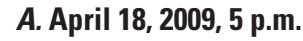

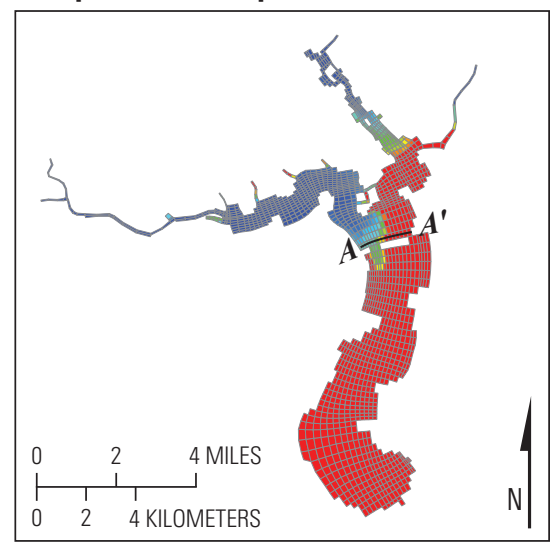

\section{B. April 18, 2009, 8 p.m.}

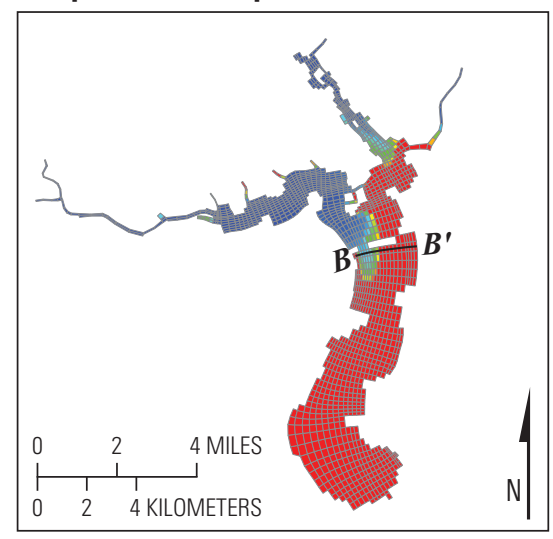

C. April 19, 2009, 5 p.m.

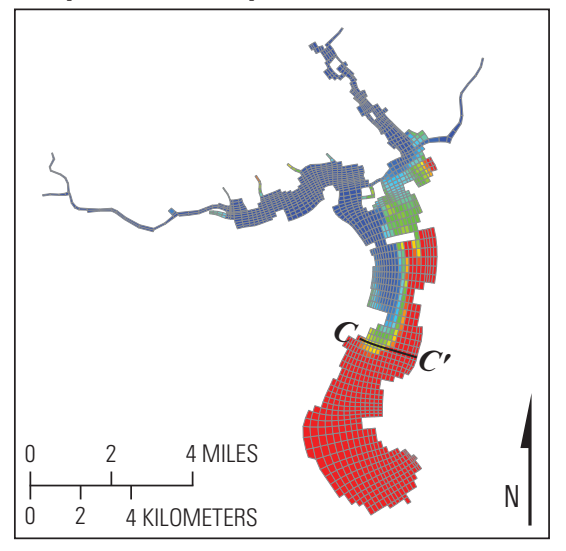

EXPLANATION

Water residence time, in days, depth averaged per column

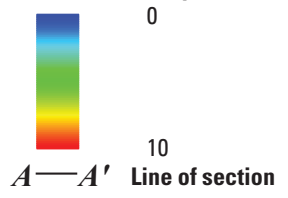

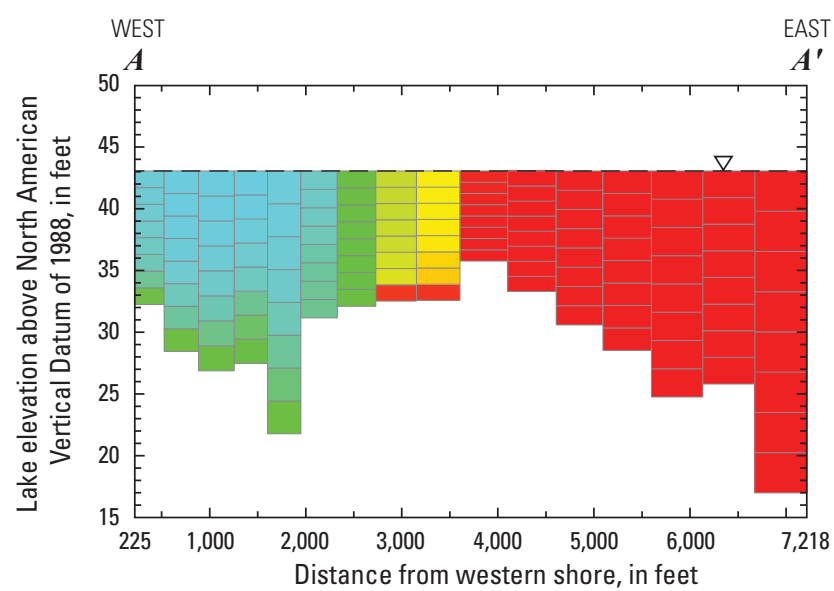
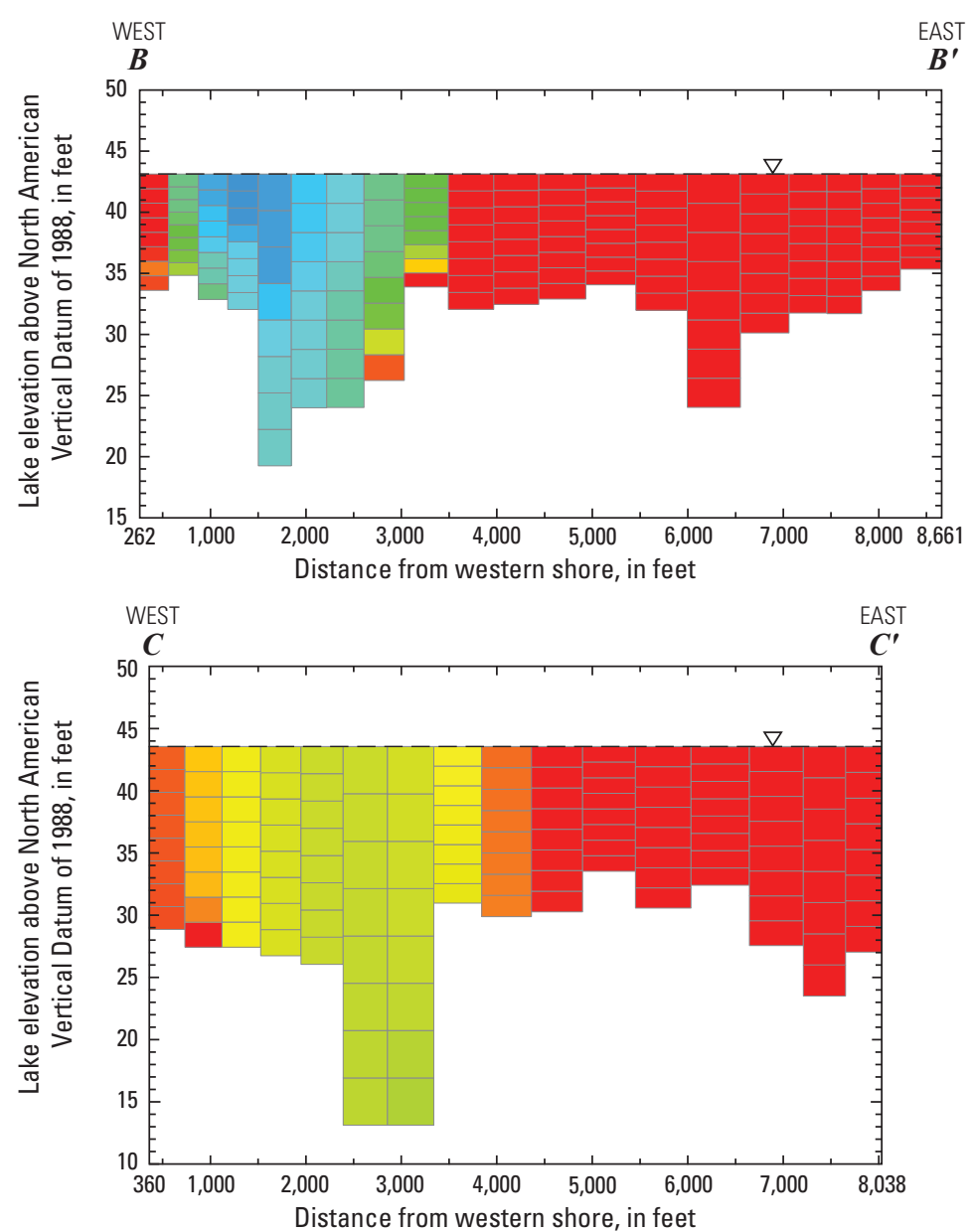

EXPLANATION

Water residence time, in days, per cell

0

10

$-\nabla-$ Estimated stage

Figure 20. Examples of modeled changes in water residence time in Lake Houston, near Houston, Texas, from April 19, 2009, to April 22, 2009, in response to an inflow event. Changes in water residence time are depicted with plan views and cross section profile views for different dates and times. A, April 18 at 5 p.m. B, April 18 at 8 p.m. C, April 19 at 5 p.m. D, April 21 at 12 a.m. E, April 22 at 12 p.m. 
D. April 21, 2009, 12 a.m.

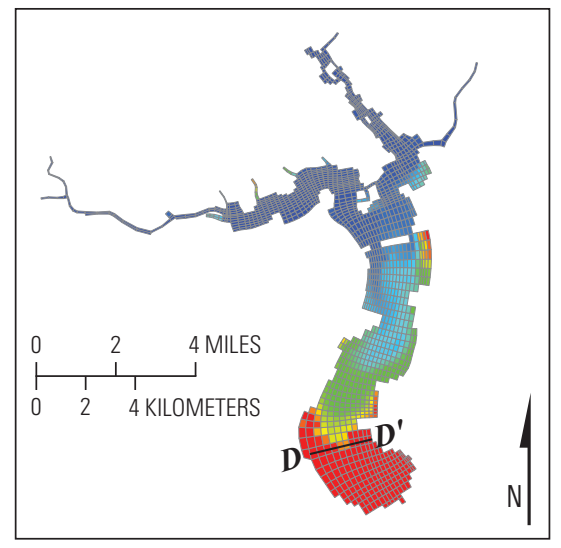

E. April 22, 2009, 12 p.m.
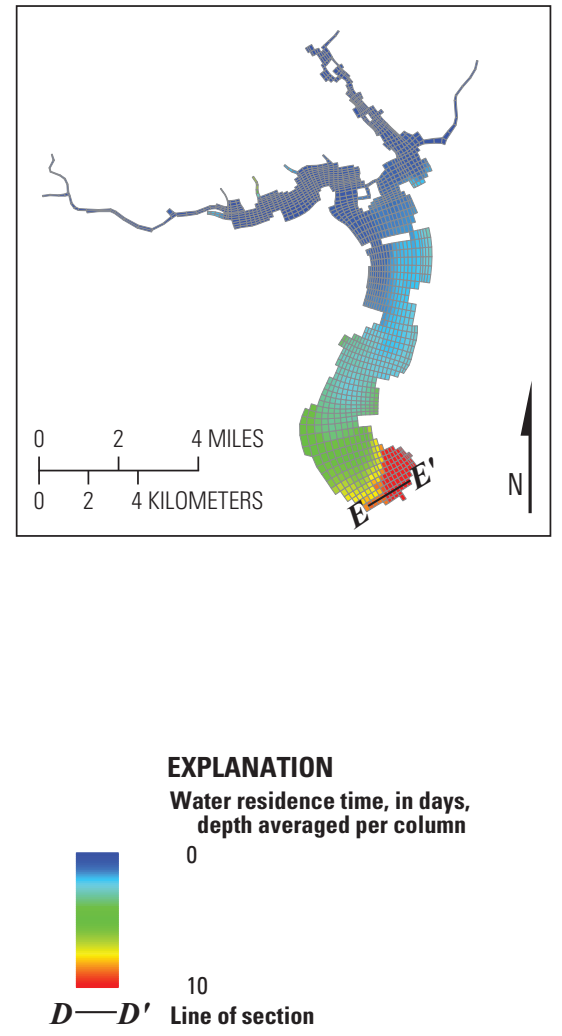
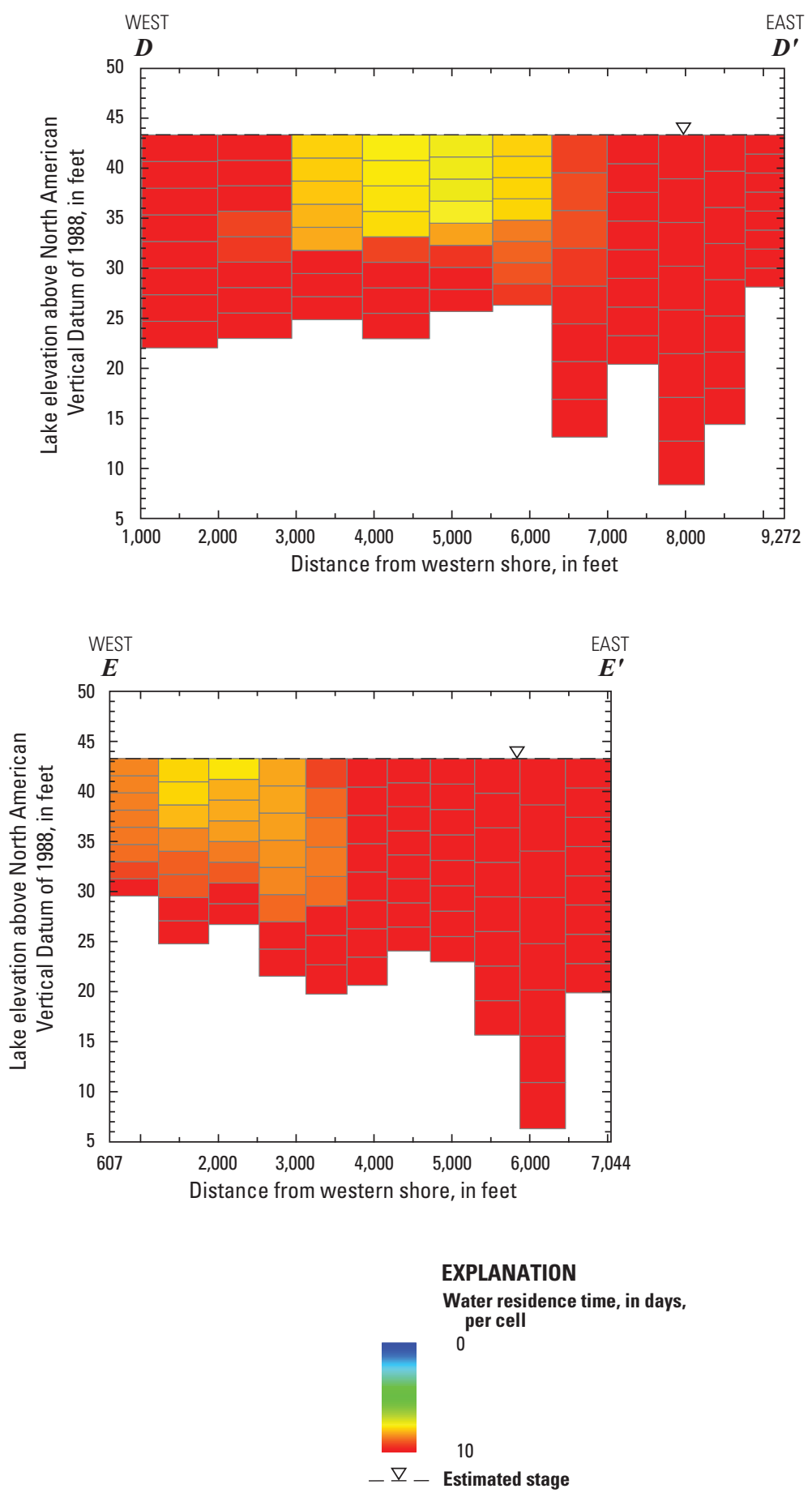

Figure 20. Examples of modeled changes in water residence time in Lake Houston, near Houston, Texas, from April 19, 2009, to April 22,2009 , in response to an inflow event. Changes in water residence time are depicted with plan views and cross section profile views for different dates and times. A, April 18 at 5 p.m. B, April 18 at 8 p.m. C, April 19 at 5 p.m. D, April 21 at 12 a.m. E, April 22 at 12 p.m.Continued 


\section{Anemill ans som}

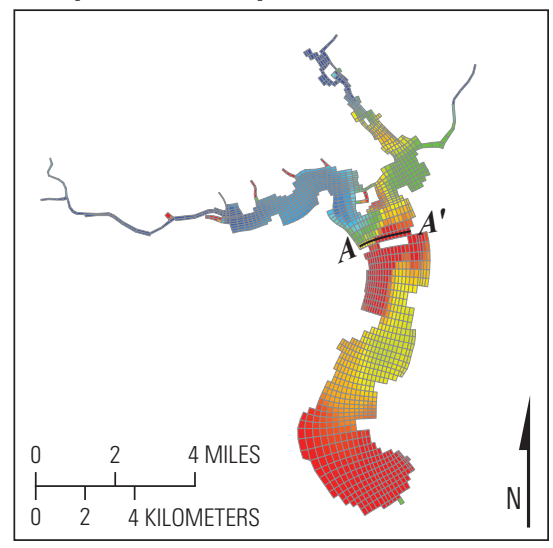

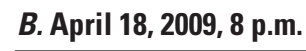

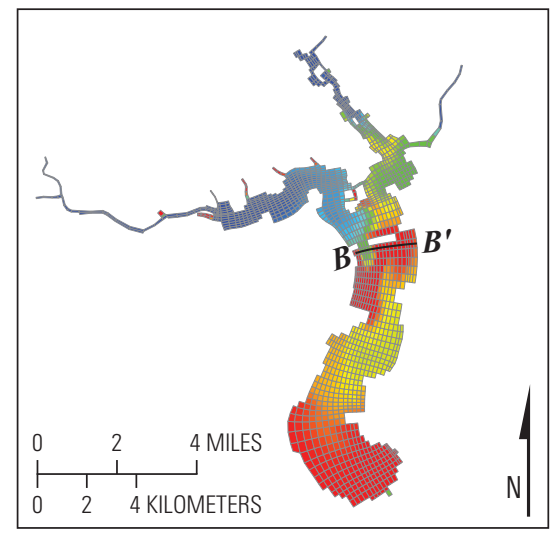

C. April 19, 2009, 5 p.m.

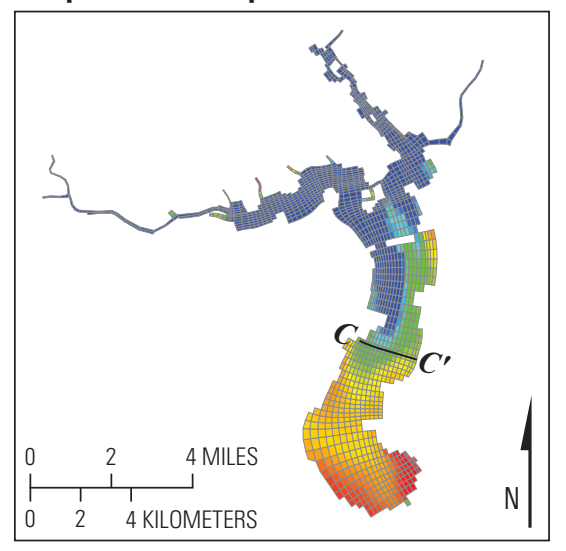

\section{EXPLANATION}

Salinity, in part per thousand, depth averaged per column

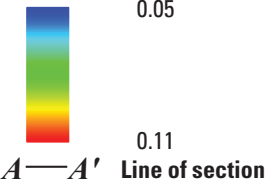

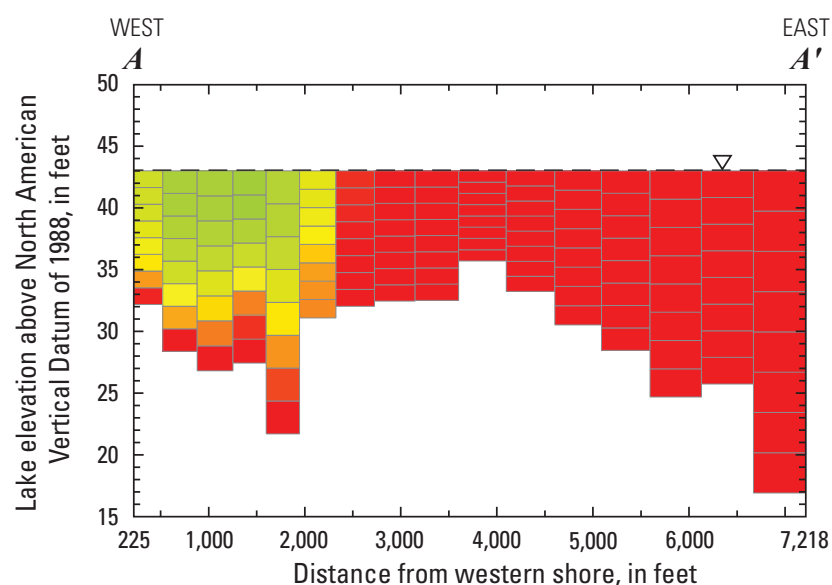
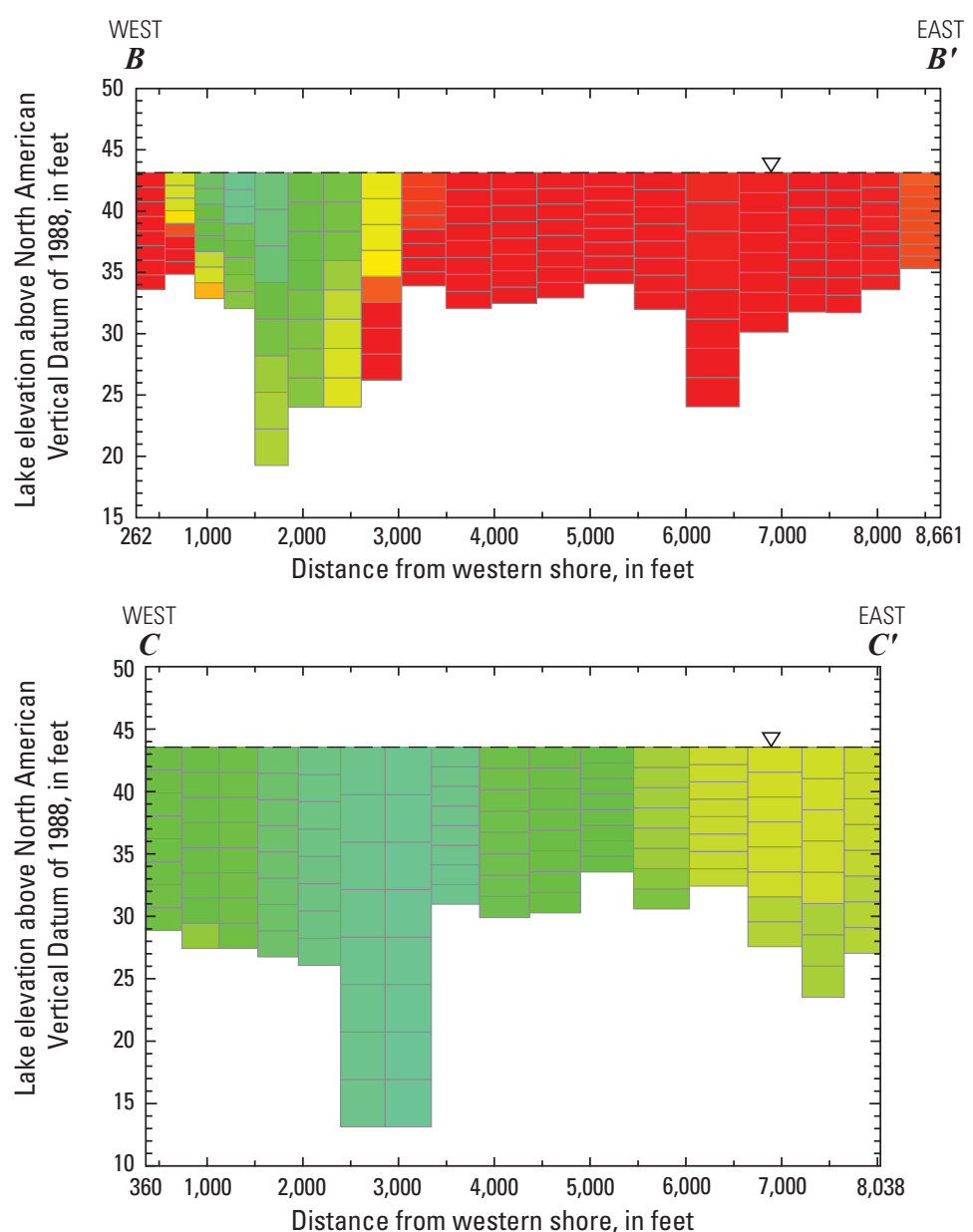

EXPLANATION

Salinity, in part per thousand, per cell

0.05

0.11

$-\nabla-$ Estimated stage

Figure 21. Examples of modeled changes in salinity in Lake Houston, near Houston, Texas, from April 19, 2009, to April 22, 2009, in response to an inflow event. Changes in salinity are depicted with plan views and cross section profile views for different dates and times. A, April 18 at 5 p.m. B, April 18 at 8 p.m. C, April 19 at 5 p.m. D, April 21 at 12 a.m. E, April 22 at 12 p.m. 
D. April 21, 2009, 12 a.m.

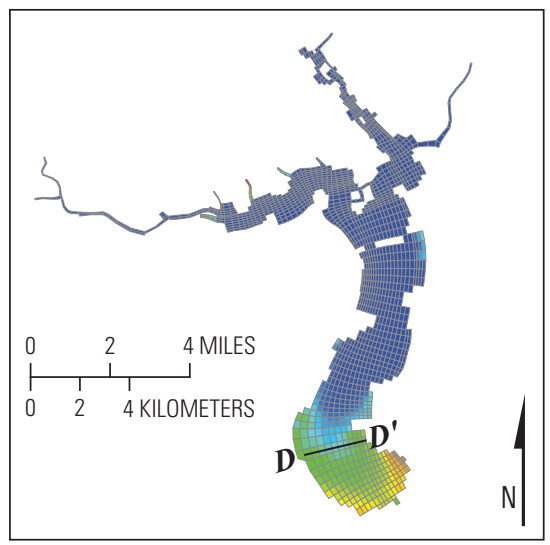

E. April 22, 2009, 12 p.m.

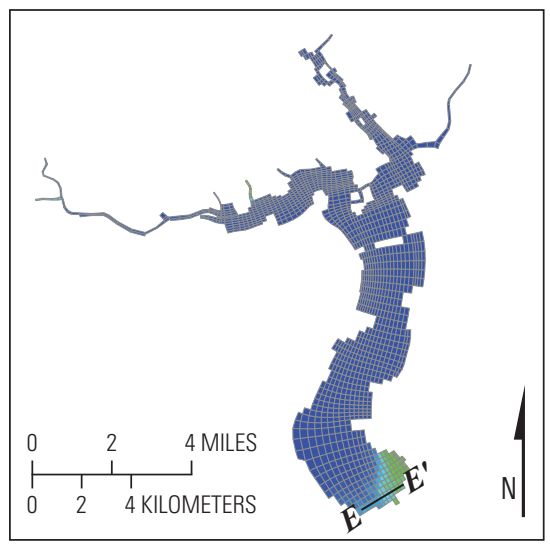

EXPLANATION

Salinity, in part per thousand, depth averaged per column

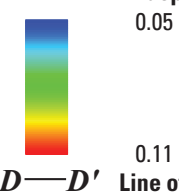

0.11

$D-D^{\prime}$ Line of section
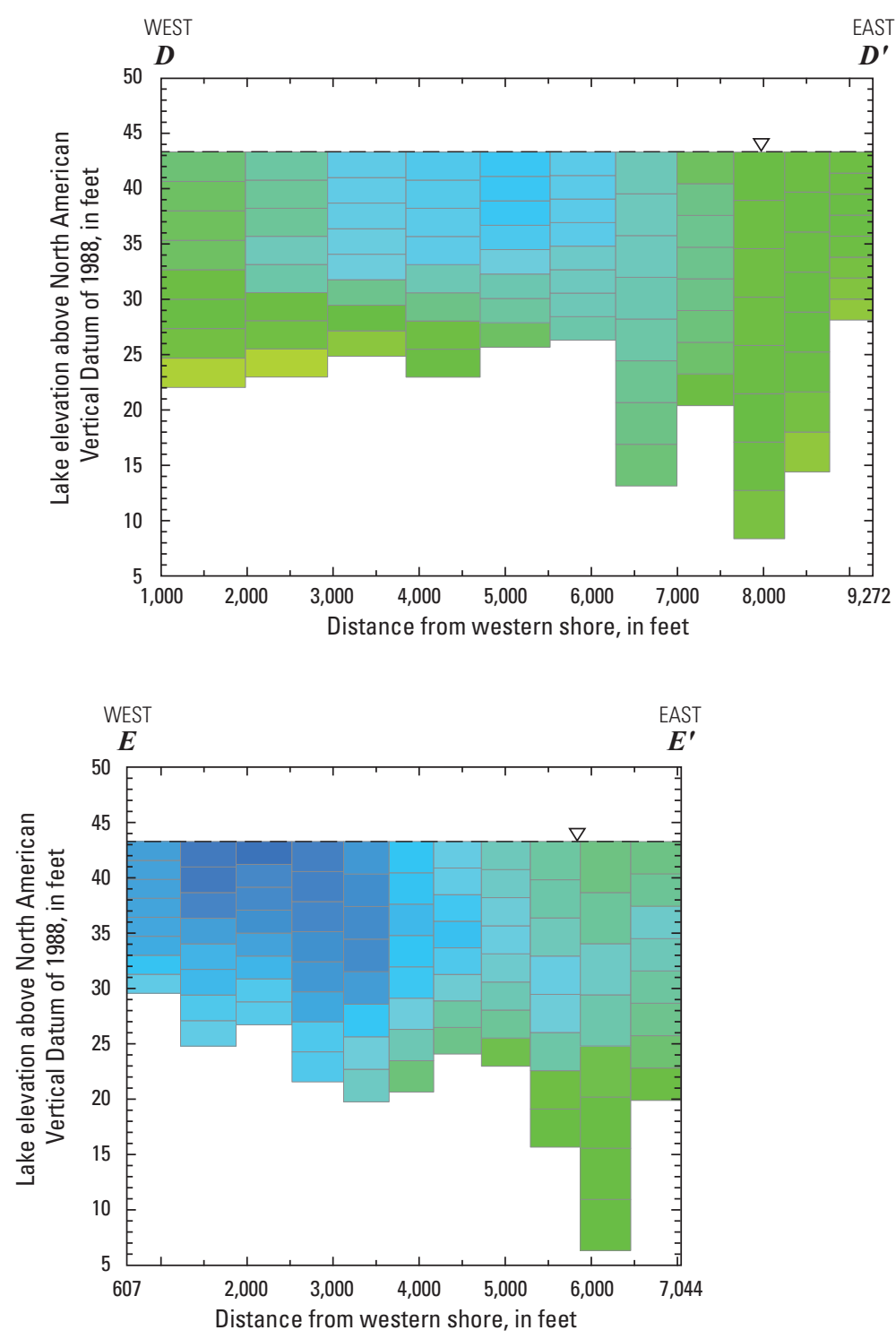

EXPLANATION

Salinity, in part per thousand, per cell

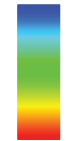

0.11

$-\nabla-$ Estimated stage

Figure 21. Examples of modeled changes in salinity in Lake Houston, near Houston, Texas, from April 19, 2009, to April 22, 2009, in response to an inflow event. Changes in salinity are depicted with plan views and cross section profile views for different dates and times. A, April 18 at 5 p.m. B, April 18 at 8 p.m. C, April 19 at 5 p.m. D, April 21 at 12 a.m. E, April 22 at 12 p.m.—Continued 

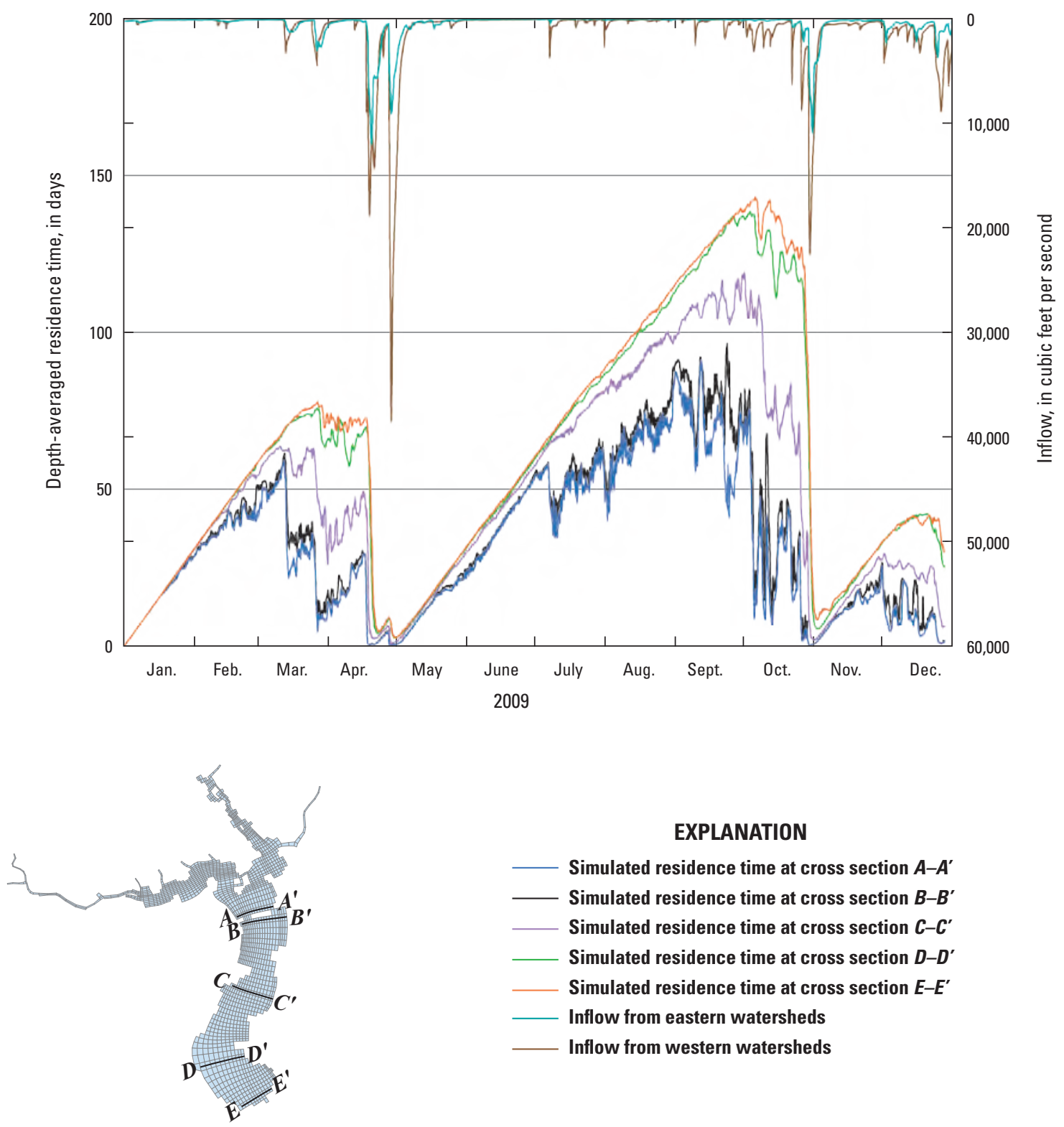

EXPLANATION

Lake Houston Environmental Fluid Dynamics Code model grid showing lines of section

Figure 22. Simulated depth-averaged residence time at each of the five representative cross sections and inflows from the western and eastern watersheds for 2009 from the Environmental Fluid Dynamics Code (EFDC) model of Lake Houston, near Houston, Texas.

Multiple smaller events in October 2009 seem to have had a cumulative effect on the residence time (fig. 22). There were insufficient inflows from the early October events to move water completely through the lake, but the combined inflows from all of the events during October 1-29, 2009, followed by the October 30-31, 2009, event affected the entire lake (fig. 22).

Two scenarios of increased inflow were chosen to demonstrate the predictive capabilities of the EFDC model. The two scenarios tested used an increased inflow of approximately $300 \mathrm{ft}^{3} / \mathrm{s}$ for 1 month (May 2010) from two watersheds: the West Fork San Jacinto River and Luce Bayou. These two inflow scenarios were chosen to mimic the effects of possible small releases or diversions of water from outside the San Jacinto River Basin into the basin (or directly into the lake) on the residence time of water in Lake Houston. These small releases and diversions would likely be from upstream lakes and rivers to help meet growing water demands in the Houston area. The inflow time series for each of the two tested locations (inflow cells shown in 
fig. 10) were modified from the original 2010 data by adding the increased inflow evenly distributed over the vertical layers at each location. New salinity time series were then computed by using equation 5 . The effects of the two inflow scenarios that were tested are illustrated for cross section $D-D^{\prime}$ (fig. 23). Flow was artificially increased by approximately $300 \mathrm{ft}^{3} / \mathrm{s}$ in May 2010 from the two watersheds, and after this 1 -month period, inflows were decreased to the inflows used to calculate the simulated residence time at cross section $D-D^{\prime}$ without the increased inflows. With the increased flows in May 2010, the simulated residence time in the lake at cross section $D-D^{\prime}$ decreased, but by early July 2010 , the simulated residence time in the lake at cross section $D-D^{\prime}$ returned to the simulation residence time in the lake without increased inflows. This pattern is as expected with small inflow events that have little effect on the overall residence time in the lake. As a result of increased inflow in May 2010, maximum residence time (as shown by the simulated residence times at cross section $D-D^{\prime}$ with and without increased flow in fig. 23) decreased slightly from approximately 106 to 97 days during late June 2010.
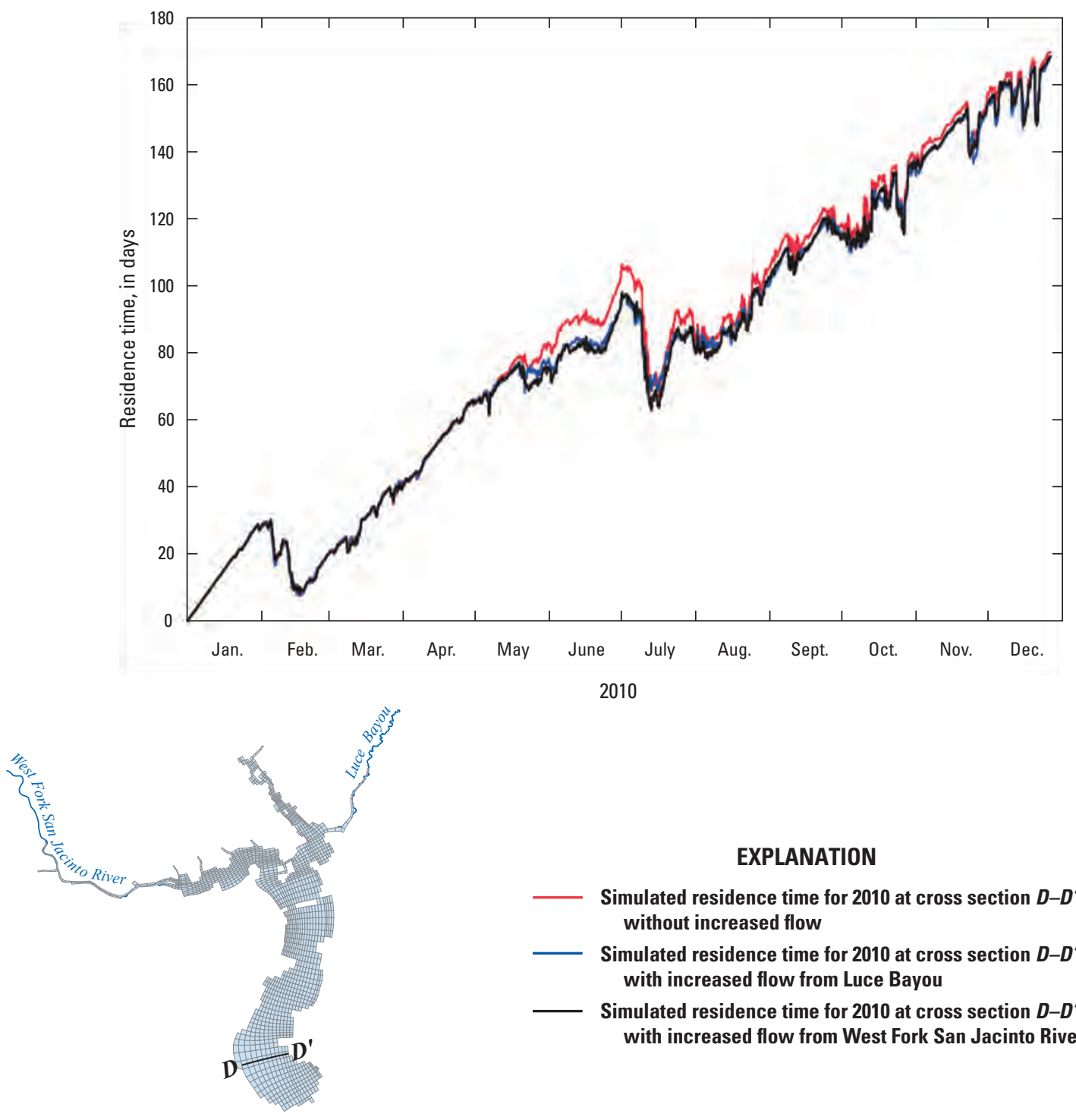

EXPLANATION

Lake Houston Environmental Fluid Dynamics Code model grid showing line of section

Figure 23. Model results for residence time over time at cross section $D-D^{\prime}$ for 2010 for increased flow from West Fork San Jacinto River and increased flow from Luce Bayou to Lake Houston, near Houston, Texas. 


\section{Summary}

The U.S. Geological Survey, in cooperation with the City of Houston, developed a three-dimensional hydrodynamic model of Lake Houston, near Houston, Texas, as a tool for evaluating the effects of different inflows on residence time of water in the lake. Lake Houston is about 25 miles northeast from the center of downtown Houston and is an important source-water-supply reservoir and recreational resource for the Houston metropolitan area. The dam impounding Lake Houston was constructed on the San Jacinto River in 1951-53 by the City of Houston to provide water for public supply and irrigation. The reservoir has a capacity of about 146,700 acrefeet and a surface area of 12,240 acres; mean depth is about 12 feet, and maximum depth is about 50 feet.

The Environmental Fluid Dynamics Code (EFDC), a grid-based, surface-water modeling package for simulating three-dimensional circulation, mass transport, sediments, and biogeochemical processes in surface waters was used for modeling Lake Houston. Initial setup of the Lake Houston EFDC model required six types of boundary condition data, which were applied to either individual grid cells or the entire model domain.

The six types of boundary condition data are (1) bathymetric data, (2) flow (inflow and outflow), (3) salinity (computed from measured specific conductance), (4) water temperature, (5) meteorological, and (6) hydraulic structure (the shape and dimensions of the dam impounding Lake Houston). The bathymetric data were based on a curvilinear horizontal grid configured to have eight vertical layers and were obtained from a 1994 hydrographic survey of Lake Houston by the Texas Water Development Board. Inflow, outflow, salinity, and water temperature boundary conditions were formulated from a comprehensive dataset collected at 10 sites and used in development of the Lake Houston EFDC model. Meteorological and solar data were collected at the National Weather Service meteorological station at George Bush Intercontinental Airport near Houston. Hydraulic structure data were based on a rating curve normalized for the length of the San Jacinto Dam that was developed to estimate outflows over the San Jacinto Dam from lake elevations.

The Lake Houston EFDC model was initially calibrated by using 2009 data and was then verified by using 2010 data. To evaluate the Lake Houston EFDC model performance, three statistics were used: mean error, root mean square error, and the Nash-Sutcliffe model efficiency coefficient (Nash coefficient). Normalized mean error and normalized root mean square error values also were computed to facilitate comparisons of mean error and root mean square error results. Simulated and measured lake-elevation values were compared at USGS reservoir station 08072000 Lake Houston near Sheldon, Tex. The accuracy of simulated salinity and water temperature values was assessed by using the salinity (computed from measured specific conductance) and water temperature that were measured at two USGS reservoir stations: USGS reservoir station 295554095093401 Lake
Houston at mouth of Jack's Ditch near Houston, Tex., and USGS reservoir station 295826095082200 Lake Houston south Union Pacific Railroad Bridge near Houston, Tex. Specific conductance and water temperature were measured at as many as four different depths at each of the two reservoir stations during 2009 and then used for assessing the accuracy of simulated values of salinity and water temperature during 2010. The performance evaluation statistics indicate that the model performed satisfactorily. The normalized mean error and normalized root mean square error for the differences between measured and simulated values for lake elevation, salinity, and temperature all closely approximated zero, and the Nash-Sutcliffe model efficiency coefficients were all larger than 0.50 , indicative of a satisfactory match between the simulated and measured data.

To understand the limitations of the Lake Houston EFDC model it is important to understand the sources of model uncertainty. Inaccuracies may be attributed to the changes in Lake Houston bathymetric surface, adjustments made to inflows in the model from streamflow rates measured at upstream streamflow-gaging stations determined by using drainage area to flow relations, specific conductance and water temperature data being collected for only two of the seven major tributaries, errors in salinity values for inflows estimated from the specific conductance data, errors in salinity values estimated for the lake, and errors associated with the rating curve for outflow over the dam. Overall, these uncertainties did not diminish the utility of this model as shown by the performance evaluation statistics.

Two scenarios of small increases in inflows were chosen to demonstrate the predictive capabilities of the EFDC model. The two scenarios tested were an increased inflow of approximately 300 cubic feet per second for 1 month (May 2010) from two watersheds: the West Fork San Jacinto River and Luce Bayou. These scenarios were chosen to mimic the effects of possible small releases or diversions of water from outside the San Jacinto River Basin into the basin (or directly into the lake) on the residence time of water in Lake Houston. During the time of increased inflow for the two scenarios tested, maximum residence time decreased slightly from approximately 106 to 97 days.

\section{References Cited}

Beussink, A.M., and Burnich, M.R., 2009, Continuous and discrete water-quality data collected at five sites on Lake Houston near Houston, Texas, 2006-08: U.S. Geological Survey Data Series 485, 18 p.

Beussink, A.M., and Graham, J.L., 2011, Relations between hydrology, water quality, and taste-and-odor causing organisms and compounds in Lake Houston, Texas, April 2006-September 2008: U.S. Geological Survey Scientific Investigations Report 2011-5121, 27 p. 
Chow, V.T., Maidment, D.R., and Mays, L.W., 1988, Applied hydrology: New York, McGraw-Hill Book Co., 572 p.

City of Houston, 2015, Public utilities division-Drinking water operations: City of Houston, accessed June 30, 2015, at http://www.publicworks.houstontx.gov/pud/ drinkingwater.html.

Conrad, D.R., 1986, The physicochemical limnology of Lake Houston reservoir, Houston, Texas: Nacogdoches, Tex., Stephen F. Austin State University, master's thesis, 207 p.

Dowell, C.L., 1964, Dams and reservoirs in Texas-Historical and descriptive information: Texas Water Commission Bulletin 6408, accessed March 18, 2015, at http://www. twdb.texas.gov/publications/reports/bulletins/doc/B6408. pdf.

Dynamic Solutions, LLC, 2015, Hydraulics \& hydrodynamics: Accessed July 29, 2015, at http:/www.dsllc.com/services/ hydraulics-hydrodynamics/.

Esri, 2011, ArcGIS Resource Center-Watershed (Spatial Analyst): Accessed August 6, 2015, at http:// help.arcgis.com/en/arcgisdesktop/10.0/help/index. html\#//009z00000059000000.htm.

Esri, 2015, ArcGIS Desktop_-Release 10: Esri, Redlands, Calif. [Also available at http://www.esri.com.]

Hamrick, J.M., 1992, A three-dimensional Environmental Fluid Dynamics Computer Code-Theoretical and computational aspects: The College of William and Mary, Virginia Institute of Marine Science, Special Report 317, $63 \mathrm{p}$.

Hamrick, J.M., 2007, The Environmental Fluid Dynamics Code user manual, US EPA version 1.0: Fairfax, Va., Tetra Tech, Inc., 231 p., accessed September 15, 2015, at http:// www2.epa.gov/exposure-assessment-models/environmentfluid-dynamics-code-efdc-download-page.

Helsel, D.R., and Hirsch, R.M., 2002, Statistical methods in water resources: U.S. Geological Survey Techniques of Water-Resources Investigations, book 4, chap. A3, 510 p.

Hem, J.D., 1985, Study and interpretation of the chemical characteristics of natural water ( $3 \mathrm{~d}$ ed.): U.S. Geological Survey Water-Supply Paper 2254, 263 p.

Hyndman, R.J., and Koehler, A.B., 2006, Another look at measures of forecast accuracy: International Journal of Forecasting, v. 22, no. 4, p. 679-688.

Ji, Z.G., 2008, Hydrodynamics and water quality-Modeling rivers, lakes and estuaries: Hoboken, N.J., John Wiley and Sons, $676 \mathrm{p}$.

Jin, Kang-Ren, Hamrick, J.H., and Tisdale, Todd, 2000, Application of three-dimensional hydrodynamic model for Lake Okeechobee: Journal of Hydraulic Engineering, v. 126 , no. 10 , p. $758-771$.
Kennedy, E.J., 1983, Computation of continuous records of streamflow: U.S. Geological Survey Techniques of Water-Resources Investigations, book 3, chap. A13, 53 p., accessed August 3, 2015, at http://pubs.usgs.gov/twri/ twri3-a13/.

Kennedy, E.J., 1984, Discharge ratings at gaging stations: U.S. Geological Survey Techniques of Water-Resources Investigations, book 3, chap. A10, 59 p., accessed August 3, 2015, at http://pubs.usgs.gov/twri/twri3-a10/.

Kilson, K.G., 1992, Mixing patterns in Lake Houston using chloride and oxygen isotope ratios as tracers: Houston, Tex., University of Houston, master's thesis, 153 p.

Kuichling, Emil, 1889, The relation between the rainfall and the discharge of sewers in populous districts: Transactions, American Society of Civil Engineers, v. 20, p. 1-56.

Larkin, T.J., and Bomar, G.W., 1983, Climatic atlas of Texas: Texas Department of Water Resources Report LP-192, $151 \mathrm{p}$.

Lee, M.T., Asquith, W.H., and Oden, T.D., 2012, Regression model development and computational procedures to support estimation of real-time concentrations and loads of selected constituents in two tributaries to Lake Houston near Houston, Texas, 2005-9: U.S. Geological Survey Scientific Investigations Report 2012-5006, 40 p.

Lee, R.W., and Rast, Walter, 1997, Light attenuation in a shallow, turbid reservoir, Lake Houston, Texas: U.S. Geological Survey Water-Resources Investigations Report 97-4064, 33 p., accessed June 30, 2015, at http://pubs. er.usgs.gov/publication/wri974064.

Lewis, E.L., 1980, The practical salinity scale 1978 and its antecedents: Institute of Electrical and Electronics Engineers (IEEE) Journal of Oceanic Engineering, v. OE-5, no. 1, p. 3-8.

Liscum, F., and East, J.W., 2000, Estimated effects on water quality of Lake Houston from interbasin transfer of water from the Trinity River, Texas: U.S. Geological Survey Water-Resources Investigations Report 00-4082, 50 p.

Liscum, F., Goss, R.L., and Rast, W., 1999, Characteristics of water-quality data for Lake Houston, selected tributary inflows to Lake Houston, and the Trinity River near Houston (a potential source of interbasin transfer), August 1983-September 1990: U.S. Geological Survey WaterResources Investigations Report 99-4129, 56 p.

Matty, J.M., Anderson, J.B., and Dunbar, R.B., 1987, Suspended sediment transport, sedimentation and resuspension in Lake Houston, Texas-Implications for water quality: Environmental Geology and Water Sciences, v. 10 , p. $175-186$. 
Miertschin, J.A., and Associates, 2007, Preliminary data review for Lake Houston watershed bacteria impairmentsSan Jacinto River Basin: Austin, Tex., prepared for Texas Commission on Environmental Quality, accessed June 30, 2015, at https://www.tceq.texas.gov/assets/public/ waterquality/tmdl/82lakehouston/82-prelimdatareview.pdf.

Moriasi, D.N., Arnold, J.G., Van Liew, M.W., Binger, R.L., Harmel, R.D., and Veith., T.L., 2007, Model evaluation guidelines for systematic quantification of accuracy in watershed simulations: Transactions of the American Society of Agricultural and Biological Engineers, v. 50, no. 3, p. 885-900.

Nash, J.E., and Sutcliffe, J.V., 1970, River flow forecasting through conceptual models part I-A discussion of principles: Journal of Hydrology, v. 10, no. 3, p. 282-290.

National Digital Elevation Program, 2004, Guidelines for digital elevation data, version 1: National Digital Elevation Program, 93 p. [Also available at http://www.ndep.gov/ TechSubComm.html.]

National Oceanic and Atmospheric Administration, 2012, Houston/Galveston, TX-Southeast Texas climate data: National Weather Service Weather Forecast Office, accessed August 3, 2015, at http://www.srh.noaa.gov/hgx/?n=climate.

National Renewable Energy Laboratory, 2012, National Solar Radiation Database, 1991-2010 update: National Renewable Energy Laboratory, accessed December 1, 2012, at http://rredc.nrel.gov/solar/old_data/nsrdb/.

Rantz, S.E., and others, 1982, Measurement and computation of streamflow, volumes 1 and 2: U.S. Geological Survey Water-Supply Paper 2175, $631 \mathrm{p}$.

Schemel, L.E., 2001, Simplified conversions between specific conductance and salinity units for use with data from monitoring stations: Interagency Ecological Program Newsletter, v. 14, no. 1, p. 17-18.

Sneck-Fahrer, D.A., Milburn, M.S., East, J.W., and Oden, J.H., 2005, Water-quality assessment of Lake Houston near Houston, Texas, 2000-2004: U.S. Geological Survey Scientific Investigations Report 05-5241, 64 p.

Stonewall, A.J., and Bragg, H.M., 2012, Suspended-sediment characteristics for the Johnson Creek basin, Oregon, water years 2007-10: U.S. Geological Survey Scientific Investigations Report 2012-5200, 32 p.

Texas Commission on Environmental Quality, 2011, Permitted wastewater outfalls (updated June 20, 2011): Texas Commission on Environmental Quality, accessed July 8, 2011, at http://www.tceq.state.tx.us/gis/sites.html.
Texas State Data Center, 2012a, Estimates of the total populations of counties and places in Texas for July 1, 2009, and January 1, 2010: Office of the State Demographer, Population Estimates and Projections Program-Texas State Data Center, accessed December 1, 2012, at http://txsdc. utsa.edu/Resources/TPEPP/Estimates/2009/2009_txpopest_ county.pdf.

Texas State Data Center, 2012b, 2008 population projections-Texas metropolitan statistical areas: Office of the State Demographer, Population Estimates and Projections Program-Texas State Data Center, accessed December 1, 2012, at http://txsdc.utsa.edu/Data/TPEPP/ Projections/Index.aspx.

Texas Water Development Board, 2012, Surface water, lake volumetric surveys: Texas Water Development Board, accessed December 1, 2012, at http://www.twdb.state.tx.us/ data/surfacewater/surfacewater_toc.asp.

Turnipseed, D.P., and Sauer, V.B., 2010, Discharge measurements at gaging stations: U.S. Geological Survey Techniques and Methods, book 3, chap. A8, 87 p.

U.S. Environmental Protection Agency, 2015, Watershed \& Water Quality Modeling Technical Support CenterHydrodynamic models: Accessed July 30, 2015, at http://www.epa.gov/athens/wwqtsc/index.html.

U.S. Geological Survey, [variously dated], National field manual for the collection of water-quality data: U.S. Geological Survey Techniques of Water-Resources Investigations, book 9, chapters A1-A9. [Also available at http://pubs.water.usgs.gov/twri9A.]

Van Metre, P.C., and Sneck-Fahrer, D.A., 2002, Water-quality trends in suburban Houston, Texas, 1954-97, as indicated by sediment cores from Lake Houston: U.S. Geological Survey Fact Sheet 040-02, 6 p.

Wagner, R.J., Boulger, R.W., Jr., Oblinger, C.J., and Smith, B.A., 2006, Guidelines and standard procedures for continuous water-quality monitors - Station operation, record computation and data reporting: U.S. Geological Survey Techniques and Methods 1-D3, 51 p., 8 attachments.

Wilks, D.S., 1995, Statistical methods in the atmospheric sciences-An introduction: San Diego, Calif., Academic Press, $467 \mathrm{p}$. 
Publishing support provided by Lafayette Publishing Service Center

Information regarding water resources in Texas is available at http://tx.usgs.gov/ 


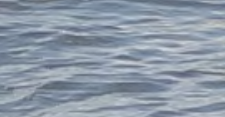

